\title{
Global panorama of studies about freshwater oligochaetes: main trends and gaps
}

\author{
Luciana Falci Theza Rodrigues ${ }^{1,2}$ \& Roberto da Gama Alves ${ }^{1,3}$ \\ 1 Universidade Federal de Juiz de Fora (UFJF), Instituto de Ciências Biológicas (ICB), Departamento de Zoologia (DEPZO0), \\ Laboratório de Invertebrados Bentônicos (LIB). Juiz de Fora, MG, Brasil. \\ ${ }^{2}$ ORCID: 0000-0002-7610-870X. E-mail: biofalci@hotmail.com (corresponding author) \\ 3 ORCID: 0000-0001-8392-2091. E-mail: gama.alves@ufjf.edu.br
}

\begin{abstract}
Freshwater oligochaetes have been studied over the years in a wide range of habitats around the world. To analyse the data published about freshwater oligochaetes in the 31 year period between 1985 and 2015, we searched for documents in the ISI Web of Science, Scopus and SciELO databases. A total of 979 works were evaluated from 184 periodicals. The United States is the country with the most publications about aquatic oligochaetes, followed by France, Germany and Italy. Works related to the ecology and ecotoxicology of these organisms are most abundant. Studies carried out in the laboratory are most frequent, consisting of investigations involving bioassays, morphology, genetics and molecular biology. The results also show that spring, cave water bodies and swamps have been studied less than any other aquatic habitat and that countries of the Southern Hemisphere are under-represented in the studies of aquatic oligochaetes. Hence, there is a need for increased efforts to fill in gaps in the knowledge about these oligochaetes.
\end{abstract}

Key-Words. Database; Literature review; Scientific production; Oligochaeta.

\section{INTRODUCTION}

Oligochaetes in freshwater ecosystems are composed of over 1,100 known species (Martin et al., 2008). Despite their high richness and representation in various aquatic habitats (streams, rivers, lakes, reservoirs), the oligochaetes have not received proper attention in hydrobiology studies (Sambugar, 2007). Their identification in the majority of publications is at a relatively unrefined taxonomic level, such as class or family, causing a gap in knowledge about the species level. Their small body size, absence of peculiar morphological structures (Sambugar, 2007) and "poor" appearance, described by Righi (1984) as "lack of beauty and eye-catching behaviors", are factors contributing to the relative lack of interest of researchers.

Studies of freshwater oligochaetes in the Neotropical realm started in the nineteenth century, carried out by vanguard researchers like Michaelsen, Stephenson, Beddard, Cognetti de Martiis and Cernosvitov, among others (Gavrilov, 1981). In Brazil, knowledge about limnic oligochaetes was pioneered by the taxonomic studies of the husband-wife team Eveline Du BoisReymond Marcus and Ernest Marcus starting in 1934, and by Gilberto Righi at the end of the 1960s. Subsequently (as of 2000), works about ecology such as Alves \& Lucca (2000), Alves et al. (2006, 2008), Gorni \& Alves (2006, 2008a,b, 2012, 2014), Behrend et al. (2009, 2012), Martins \& Alves
(2008, 2010), Ragonha \& Takeda (2014), Ragonha et al. (2014), Gorni et al. (2015), Oda et al. (2015), Petsch et al. (2015) and Rodrigues et al. (2013, $2015,2016)$, and on aspects of the reproductive biology by Lobo \& Alves $(2011 \mathrm{a}, \mathrm{b})$, have contributed to the knowledge of these invertebrates in Brazil.

In other biogeographic regions, such as the Nearctic (Wetzel et al., 2006, 2007) and the Australasian (Pinder et al., 2006), information about worms is plentiful (Martin et al., 2008). Although more studies about aquatic oligochaetes have been performed in these regions, not all habitats have been equally investigated. For example, little is known about the diversity of oligochaetes in groundwater (Giani et al., 2001) and springs (Dumnicka, 2006).

In this context, the objective of this work was to analyze the publications on freshwater oligochaetes over time and in different geopolitical regions of the world, and based on the results to verify trends and provide information to help guide efforts to fill in the main knowledge gaps identified.

\section{MATERIAL AND METHODS}

To analyze the theme "freshwater oligochaetes", we used the bibliographic production from 1985 to 2015. The search for data was performed using the following databases: ISI Web of Science (Thomson Reuters), Scopus (Elsevier) and SciELO (Scientific 
Electronic Library Online). We used these three bases due to the different scopes regarding the number and quality of the scientific periodicals indexed. The keywords were: "aquatic oligochaet" ${ }^{*}$ or "*water oligochaet" or clitellat* or tubificid* or naidid* or lumbriculid* or lumbriculus* or tubifex* . Because the group is paraphyletic, many researchers avoid using the name "oligochaete" or "Oligochaeta" and instead use the term "clitellate" or "Clitellata". For this reason, we included this as a keyword. Furthermore, in many documents only the family names are given, not "oligochaete", so we also included the main families of freshwater oligochaetes, as well as some of their genera.

We selected the "Title" option for advance search, to filter only specific works about the theme of interest. We only considered articles, reviews, notes, books and book chapters. Proceedings papers, meeting abstracts and editorial pieces were excluded from the analysis. Often these types of writings wind up being redundant, such as when the results presented in proceeding abstracts are later included in scientific articles. All the documents found were analyzed individually and those found not to be related to the theme were removed. The databases were searched in August 2016.

The elements tallied in each article were: (i) year of publication; (ii) number of publications per country/ continent (where the study was conducted); (iii) area of knowledge (genetics, taxonomy, ecology, morphology, among others); and (iv) type of habitat where the study was performed (river, stream, lake, reservoir, spring, laboratory, among others).

\section{RESULTS}

We found 2,325 results for publications containing the keywords in their titles. Of this number, 1,240 (53.33\%) specifically investigated freshwater oligochaetes (the rest were related to terrestrial, marine, estuarine forms or clitellate other than oligochaetes, such as Hirudinea and Branchiobdellida). Of all the publications found referring to freshwater oligochaetes, 33 came from consulting SciELO, 621 from Scopus and 586 from Web of Science (Fig. 1). However, some of these works were found in more than one of the databases, so the final total was 979 publications analyzed analyzed (see Supporting Information).

The works analyzed were mainly scientific articles (97.34\%). The others were reviews $(1.63 \%)$, notes $(0.82 \%)$ and book chapters $(0.20 \%)$. These works were published in 184 different periodicals, but most of them (about $73 \%$ ) contained fewer than five works. The most frequent periodicals were Hydrobiologia (24.56\%), Environmental Toxicology and Chemistry (7.63\%) and Annales de Limnologie-International Journal of Limnology (3.66\%).

The number of publications on freshwater oligochaetes fluctuated during the years studied, without showing a gradual growth trend. The two years with the largest numbers (Fig. 2A) were 1987 (55 works) and 1999 (54 works). On the other hand, there was a rising trend in the sum of the articles in the 10-year periods (Fig. 2B).
Studies related to ecology, ecotoxicology and taxonomy were most abundant. "Others" in the topic category included works related to oligochaetes as food for fish and use in activated sludge reduction (Fig. 3A). The interest in ecotoxicology increased in the three decades, as did studies involving taxonomy and genetics/phylogeny (Fig. 3B). Among the oligochaetes species most cited and analyzed are Tubifex tubifex (Müller, 1774), Lumbriculus variegatus (Müller, 1774), Branchiura sowerbyi Beddard, 1892, Limnodrilus hoffmeisteri Claparède, 1862 and Chaetogaster limnaei Von Baer, 1827, (not necessarily in

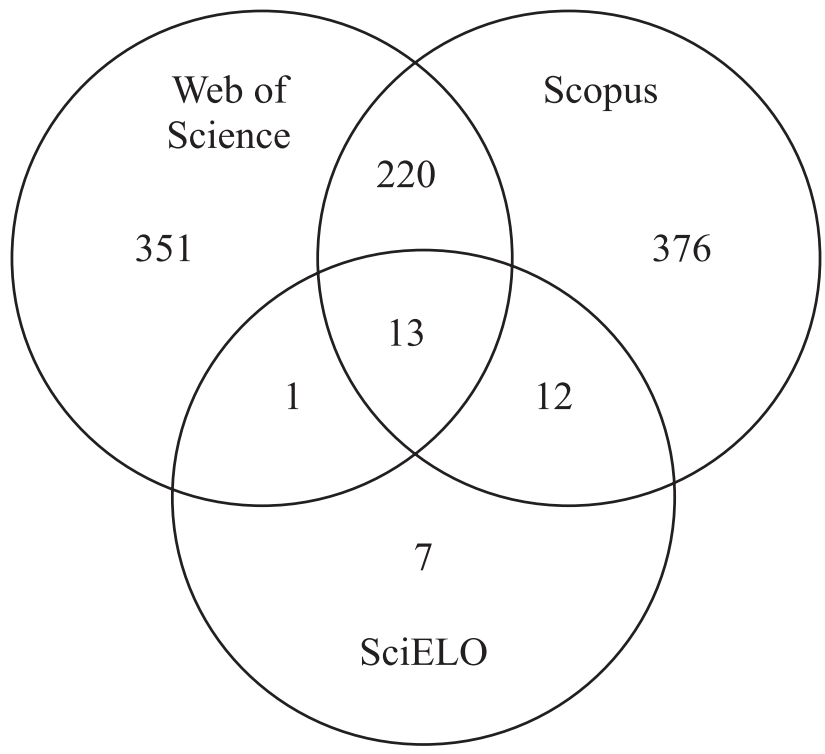

Figure 1. Total number of exclusive and shared publications on oligochaetes in freshwater habitats found in each database entre 1985 e 2015.

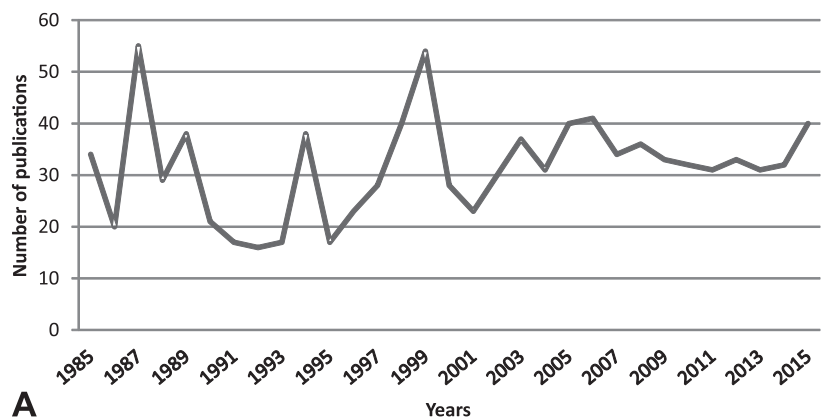

A Years

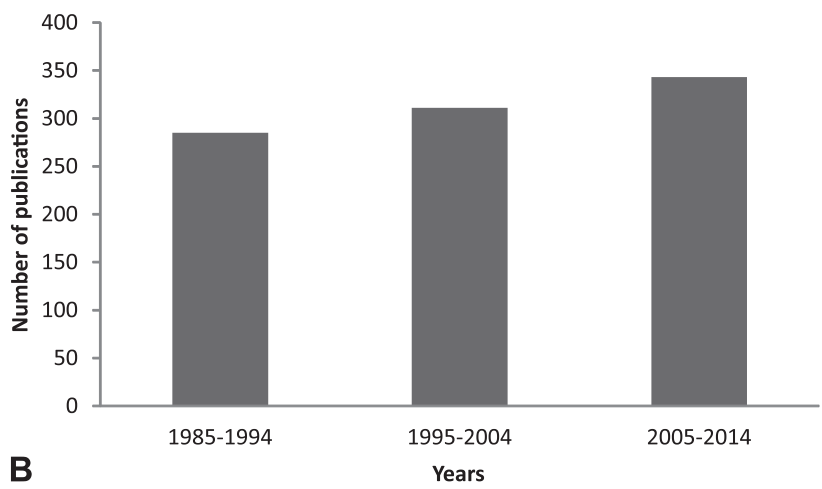

Figure 2. Number of works on freshwater oligochaetes published between 1985 and 2015 (A) and 10-year totals (B). 


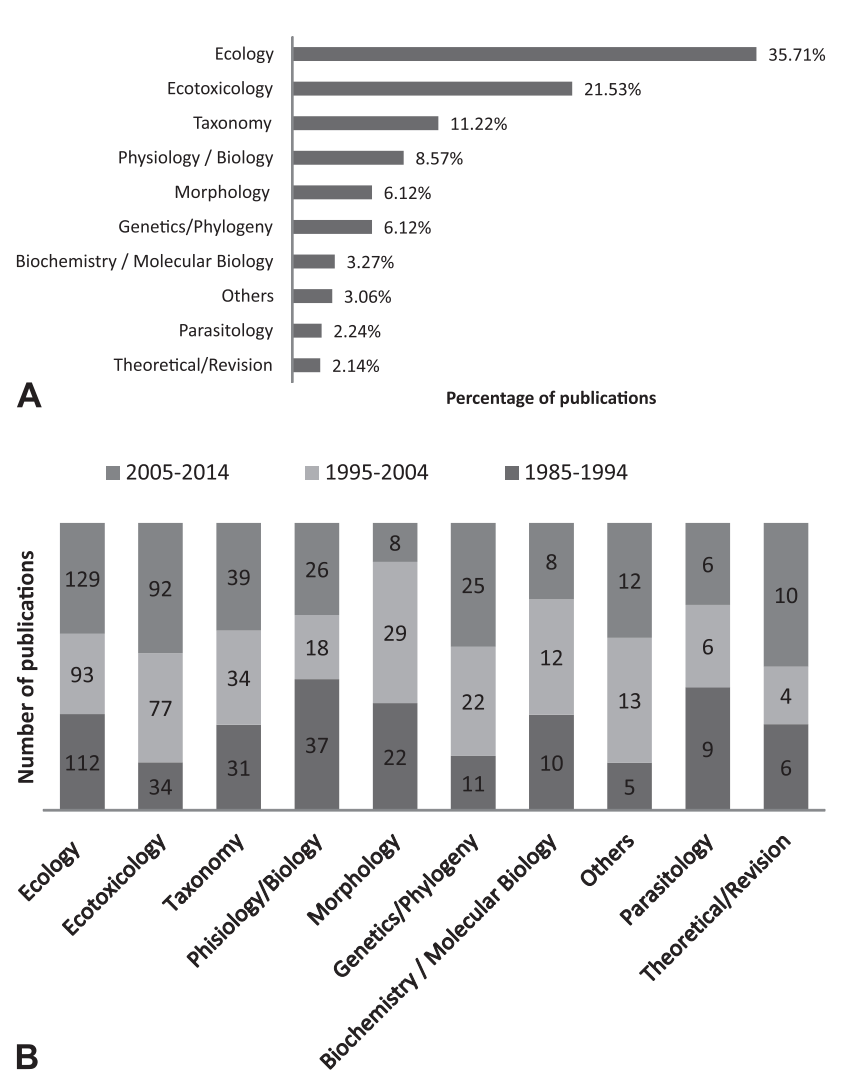

Figure 3. Percentage of works on freshwater oligochaetes published between 1985 and 2015 by area of knowledge (A) and 10-year totals (B). The "Others" category contains works related to oligochaetes as food for fish and used in reduction of activated sludge.

this order), mainly in investigations related to toxicity, organic pollution and parasitism.

We found works on oligochaetes in various aquatic environments, such as groundwater, swamps, caves, springs, rivers, streams, lakes and reservoirs. In many cases the studies analyzed the interaction of these worms with other organisms (bryophytes, macrophytes, bromeliads, sponges, snails, insects, anurans and fish). We also found experimental laboratory studies (the latter being most frequent, accounting for about $50 \%$ of the total publications). Besides empirical studies in these various aquatic environments, we also found studies only using bibliographic data as primary source. Springs, cave water bodies and swamps were the least studied habitat in the past 31 years, representing under $2.5 \%$ of the published works (Fig. 4).

With respect to global distribution, studies of freshwater oligochaetes occurred in 51 countries, the five leading ones being the United States $(n=157)$, France $(n=72)$, Germany $(n=60)$, Italy $(n=59)$ and Canada $(n=52)$. Brazil and Argentina are the only Latin American countries with more than 30 published studies and appearing among the 15 leading countries (Fig. 5A). In the continental breakdown, Europe showed the highest percentage, with about $50 \%$ of the total, while Oceania and Africa each accounted for under $1 \%$. Approximately $2.5 \%$ of the papers analyzed did not mention the place where the study was conducted, so they are included in the "Undefined" category (Fig. 5B).

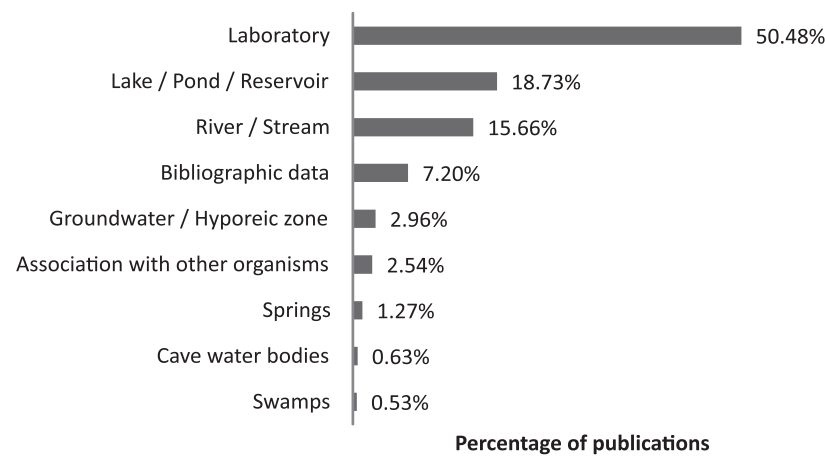

Figure 4. Percentage of works on freshwater oligochaetes published between 1985 and 2015 by habitat/ecosystem where the study was conducted.
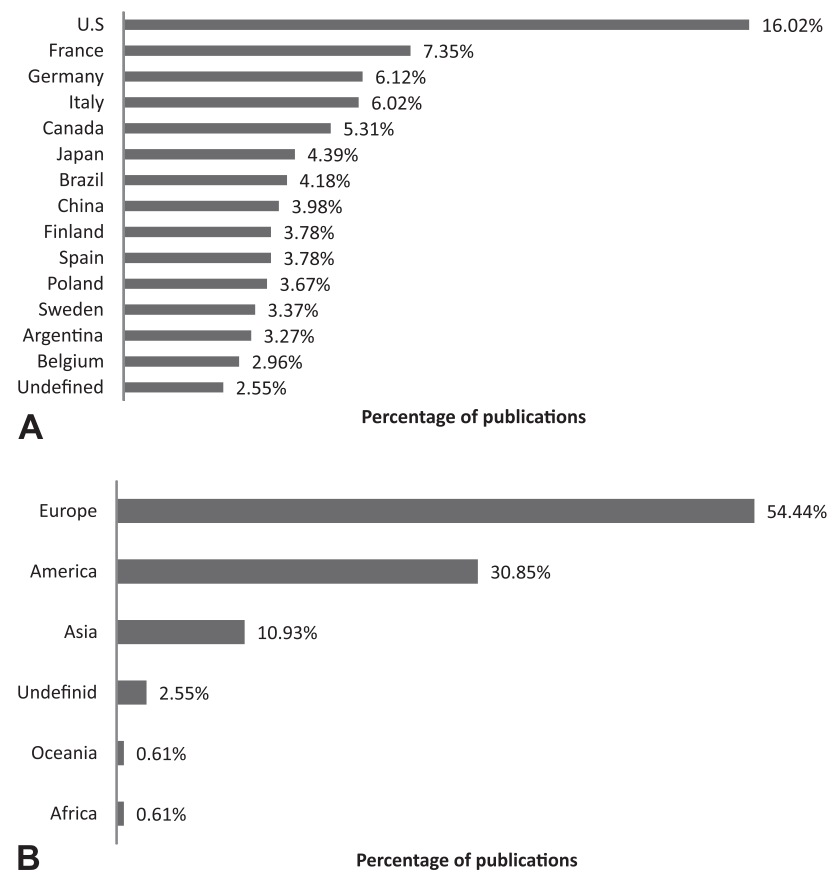

Figure 5. Percentage of works on freshwater oligochaetes published between 1985 and 2015 by continent (A) and by countries (15 leading ones in number of publications) (B).

\section{DISCUSSION}

Freshwater oligochaetes have been the target of studies involving biodiversity of aquatic habitats in preserved areas, biomonitoring, water quality analysis and toxicity monitoring in many countries. Therefore, researchers have published their findings in periodicals with different scopes, both widely distributed and limited, such as regional or local periodicals. This is shown by the survey of the three databases chosen here.

SciELO is a narrower database, because it only includes periodicals from countries in Latin America, along with South Africa, Spain and Portugal. For this reason, substantially fewer publications were found in this database. In contrast, Web of Science (WoS) and Scopus have global scope and presented a larger number of publications. The WoS database indexes more than 12,700 periodicals, in a wide range of scientific fields, and the majority of its titles are in English (Lopes et al., 2012). Only about 2.5\% 
of the titles are from Latin American countries, explaining the small overlap of articles with SciELO. On the other hand, the Scopus base contains about 18,000 titles and has more European content than WoS, as well as including more languages besides English (about $60 \%$ of the coverage is countries other than the U.S.) (Lopes et al., 2012). Many periodicals not indexed in WoS are indexed in Scopus, explaining the larger coverages of articles in the latter database and the greater overlap with SciELO.

According to Brinkhurst (1999), the majority of publications on oligochaetes up to 1970 were taxonomic, containing descriptions of new species and re-descriptions of known ones. In the 31 years examined (1985-2015), studies with ecological focus stood out over the other areas of knowledge, although the number of taxonomic works also continued to rise in the those years. Besides this, there was a strong trend for increase of works related to toxicology (Rodriguez \& Reynoldson, 2011). The increase in the number of publications in general with time and regarding determined academic fields, even if timid in some cases, is an indication of the increase in the number of researchers and/or interest in investigating certain themes. The increase in the total number of publications also indicates the scientific advances made, considering that the number of publications is one of the metrics most often used to quantify the evolution of science (Lima-Ribeiro et al., 2007).

Bioassays and toxicity tests were largely responsible for the large number of laboratory studies found, and for the same reason, species such as Tubifex tubifex, Branchiura sowerbyi and Lumbriculus variegatus were frequently found in the titles. These species are typical models in ecotoxicological studies due to their high reproductive rate and eash cultivation (Lobo \& Alves, 2011a). Works involving biology, morphology, genetics and molecular biology also accounted for a large number of publications about laboratory experiments.

Studies of oligochaetes in springs were less frequent, as were those focused on swamps and water bodies in caves. With respect to springs, for example Cantonati et al. (2012) also affirm that in general this type of habitat is less frequently studied than other aquatic ecosystems. Therefore, these three ecosystems deserve greater attention in future studies. This rarity of studies of oligochaetes in some aquatic environments makes it urgent to learn more about the fauna of these habitats, which are facing increasing degradation from human activity.

Nearly half of the works analyzed were European. The European continent has 61 countries, and of these, studies were found about freshwater oligochaetes in 30 of them, with a large number of overall publications. The American continent as a whole (North, Central and South America) was in second place, although the largest number of works were from the United States. Countries of Africa and Oceania were under-represented in studies of freshwater oligochaetes. This result indicates a need for efforts to fill in gaps in various areas of knowledge of these organisms, as well as the preservation of aquatic ecosystems in these regions. In particular, these regions contain many forests and aquatic ecosystems that under threat of human activity (Nicacio \& Juen, 2015), accounting for nearly half (44\%) of the global hotspots.

Among Latin American countries, considered emerging or developing, Brazil appeared in first place in the number of publications between 1985 and 2015. Most of these studies were performed in the states of São Paulo, Minas Gerais and Paraná. Many species of oligochaetes are endemic to tropical regions, mainly in South America (Christoffersen, 2010). Studies to take inventory of fauna and learn the ecological relations between species and the environment are very important to formulate policies to preserve biodiversity, especially in forest regions under strong threat such as the Atlantic Forest fragments in Brazil.

\section{CONCLUSION}

According to the literature review, some tendencies and gaps exist in knowledge about freshwater oligochaetes that deserve attention. First of all, although there was a good deal of yearly upward and downward fluctuation in the number of works published, the trend considering the totals in the three 10-year periods was increasing, albeit modestly. This increase in the general number of publications was accompanied by specific increases in certain areas of knowledge, such as ecotoxicology, genetics/phylogeny and taxonomy. Descriptions, rediscriptions and reclassifications of species became more frequent, spurred by advances in molecular techniques, applied alone or in combination with morphological investigation, through interactive taxonomy, an important tool in various areas of biology. Nevertheless, despite the modest increase in the number of publications, studies of freshwater oligochaetes are still scarce. There are few specialists devoted to studying freshwater oligochaetes, leading to many gaps regarding geographic region and habitat focus. The Southern Hemisphere has been under-represented in studies of these organisms, mainly in countries of Africa and Oceania, while springs, caves and swamps are relatively neglected habitats. Therefore, more varied investigation is necessary to deepen understanding of freshwater oligochaetes and provide insights about their global diversity, and to guide efforts to protect their habitats.

In closing, if readers want to start studying or deepen their studies of aquatic oligochaetes, we suggest Reynolds \& Wetzel (2018). The site is very comprehensive, containing updated references, nomenclature and species counts as well as news about events and related sites.

\section{ACKNOWLEDGEMENTS}

We would like to thank the anonymous reviewers for their suggestions and contributions to this manuscript, the Brazilian Office to Improve University Personnel (Coordenação de Aperfeiçoamento de Pessoal de Nível Superior - CAPES) for the scholarship grant, and the 
the National Council for Scientific and Technological Development (Conselho Nacional de Desenvolvimento Científico e Tecnológico - CNPq) for funding (Process: 304552/2015-1).

\section{REFERENCES}

Alves, R.G. \& Lucca, J.V. 2000. Oligochaeta (Annelida: Clitellata) como indicador de poluição orgânica em dois córregos pertencentes à Bacia do Ribeirão do Ouro Araraquara (São Paulo, Brasil). Brazilian Journal of Ecology, 1: 112-117.

Alves, R.G.; Marchese, M.R. \& Escarpinati, S.C. 2006. Oligochaeta (Annelida, (litellata) in lotic environments in the state of São Paulo, Brazil. Iheringia Série Zoologia, 96: 431-435.

Alves, R.G.; Marchese, M.R. \& Martins, R.T. 2008. Oligochaeta (Annelida, Clitellata) of lotic environments at Parque Estadual Intervales (São Paulo, Brazil). Biota Neotropica, 8: 21-25.

Behrend, R.D.L.; Fernandes, S.E.P.; Fujita, D.S. \& Takeda, A.M. 2009. Eight years of monitoring aquatic Oligochaeta from the Baía and Ivinhema Rivers. Brazilian Journal of Biology, 69: 559-571.

Behrend, R.D.L.; Takeda, A.M.; Gomes, L.C. \& Fernandes, S.E.P. 2012. Using oligochaeta assemblages as an indicator of environmental changes. Brazilian Journal of Biology, 72: 873-884.

Brinkhurst, R.0. 1999. Retrospect and prospect: reflections on forty years of study of aquatic oligochaetes. Hydrobiologia, 406: 9-19.

Cantonati, M.; Füreder, L.; Gerecke, R.; Jüttner, I. \& Cox, E.J. 2012. Crenic habitats, hotspots for freshwater biodiversity conservation: toward an understanding of their ecology. Freshwater Science, 31: 463-480.

Christoffersen, M.L. 2010. Continental biodiversity of South American oligochaetes: the importance of inventories. Acta Zoologica Mexicana, 2: 35-46.

Dumnicka, E. 2006. Composition and abundance of oligochaetes (Annelida: Oligochaeta) in springs of Kraków-Częstochowa Upland (Southern Poland): effect of spring encasing and environmental factors. Polish Journal of Ecology, 54: 231-242.

Gavrilov, K. 1981. Oligochaeta. In: Hurlbert, S.H.; Rodriguez, G. \& Santos, N.D. (Eds.). Aquatic biota of tropical South America, 2: Anarthropoda. San Diego, San Diego State University. p. 170-190.

Giani, N.; Sambugar, B.; Rodriguez, P. \& Martínez-Ansemil, E. 2001. Oligochaetes in southern European groundwater: new records and an overview. Hydrobiologia, 463: 65-74.

Gorni, G.R. \& Alves, R.G. 2006. Naididae (Annelida, Oligochaeta) associated with Pomacea bridgesii (Reeve) (Gastropoda, Ampullaridae). Revista Brasileira de Zoologia, 23: 1059-1061.

Gorni, G.R. \& Alves, R.G. 2008a. Naididae species (Annelida: Oligochaeta) associated with the sponge Metania spinata (Carter, 1881) (Porifera: Metaniidae) from a southeastern Brazilian reservoir. Acta Limnologica Brasiliensia, 20: 261-263.

Gorni, G.R. \& Alves, R.G. 2008b. Oligochaeta (Annelida: Clitellata) em córregos de baixa ordem do Parque Estadual de Campos do Jordão (São Paulo, Brasil). Biota Neotropica, 8: 161-165.

Gorni, G.R.\&Alves, R.G. 2012. Oligochaetes (Annelida, Clitellata) in a neotropical stream: a mesohabitat approach. Iheringia Série Zoologia, 102: 106-110.

Gorni, G.R. \& Alves, R.G. 2014. Influência de variáveis ambientais sobre a comunidade de oligoquetos (Annelida: Clitellata) em um córrego neotropical. Biotemas, 28: 59-66.

Gorni, G.R.; Peiró, D.F. \& Sanches, N. 2015. Aquatic Oligochaeta (Annelida: (litellata) from State of São Paulo, Brazil: diversity and occurrence review. Biota Neotropica, 15: 1-8.
Lima-Ribeiro, M.S.; Nabout, J.C.; Pinto, M.P.; Moura, I.0.; Melo, T.L.; Costa, S.S. \& Rangel, T.F.L.V.B. 2007. Análise cienciométrica em ecologia de populações: importância e tendências dos últimos 60 anos. Acta Scientiarum, Biological Sciences, 29: 39-47.

Lobo, H. \& Alves, R.G. 2011a. Reproductive cycle of Branchiura sowerbyi (Oligochaeta: Naididae: Tubificinae) cultivated under laboratory conditions. Zoologia, Curitiba, 28: 427-431.

Lobo, H. \& Alves, R.G. 2011b. Influence of body weight and substrate granulometry on the reproduction of Limnodrilus hoffmeisteri (Oligochaeta: Naididae: Tubificinae). Zoologia, Curitiba, 28: 558-564.

Lopes, S.; Costa, M.T.; Fernández-Llimós, F.; Amante, M.J. \& Lopes, P.F. 2012. A Bibliometria e a Avaliação da Produção Científica: indicadores e ferramentas. In: Congresso Nacional de Bibliotecários, Arquivistas e Documentalistas, $11^{\circ}$. Actas. Lisboa, B.A.D.

Martin, P.; Martínez-Ansemil, E.; Pinder, A.; Timm, T. \& Wetzel, M.J. 2008. Global diversity of Oligochaetous clitellates ("Oligochaeta"; Clitellata) in freshwater. Hydrobiologia, 595: 117-127.

Martins, R.T. \& Alves, R.G. 2008. Occurrence of Naididae (Annelida: Oligochaeta) from three gastropod species in irrigation fields in southeastern Brazil. Biota Neotropica, 8: 255-257.

Martins, R.T. \& Alves, R.G. 2010. Occurrence of Chaetogaster limnaei K. von Baer, 1927 (Oligochaeta, Naididae) associated with Gastropoda mollusks in horticultural channels in Southeastern Brazil. Brazilian Journal of Biology, 70: 1055-1057.

Nicacio, G. \& Juen, L. 2015. Chironomids as indicators in freshwater ecosystems: an assessment of the literature. Insect Conservation and Diversity, 8(5): 393-403.

Oda, F.H.; Petsch, D.K.; Ragonha, F.H.; Batista, V.G.; Takeda A.M. \& Takemoto, R.M. 2015. Dero (Allodero) lutzi Michaelsen, 1926 (Oligochaeta: Naididae) associated with Scinax fuscovarius (Lutz, 1925) (Anura: Hylidae) from Semi-deciduous Atlantic Rain Forest, southern Brazil. Brazilian Journal of Biology, 75: 86-90.

Petsch, D.K.; Ragonha, F.H.; Gimenez, B.C.G.; Barboza, L.G.A.\& Takeda, A.M. 2015. Partitioning beta diversity of aquatic Oligochaeta in different environments of a Neotropical floodplain. Acta Scientiarum. Biological Sciences, 37: 41-49.

Pinder, A.M.; Eberhard, S.M. \& Humphreys, W.F. 2006. New phalodrilines (Annelida: Clitellata: Tubificidae) from Western Australian groundwater. Zootaxa, 1304: 31-48.

Ragonha, F.H. \& Takeda, A.M. 2014. Does richness of Oligochaeta (Annelida) follows a linear distribution with habitat structural heterogeneity in aquatic sediments? Journal of Limnology, 73: 146-156.

Ragonha, F.H.; Petsch, D.K.; Alves, G.H.Z.; Santana, H.S.; Michelan, T.S. \& Takeda, A.M. 2014. Tributaries as richness source for Oligochaeta assemblage (Annelida) of Neotropical dammed river. Brazilian Journal of Biology, 74: 861-869.

Reynolds, J.W. \& Wetzel, M.J. 2018. Nomenclatura Oligochaetologica - A catalogue of names, descriptions and type specimens. 2.ed. http://wwx. inhs.illinois.edu/people/mjwetzel/nomenoligo.

Righi, G. 1984. Manual de identificação de invertebrados límnicos do Brasil. Brasília, CNPq/Coordenação Editorial.

Rodrigues, L.F.T.; Leite, F.S.L. \& Alves, R.G. 2013. Inventory and distribution of Oligochaeta (Annelida, Clitellata) in first-order streams in preserved areas of the state of Minas Gerais, Brazil. Biota Neotropica, 13: 245-254.

Rodrigues, L.F.T.; Leite, F.S.L. \& Alves, R.G. 2016. Influence of bryophyte biomass and organic matter quantity on the abundance and richness of oligochaetes in forest streams with different phytophysiognomies in southeastern Brazil. Journal of Limnology, 75: 340-346.

Rodrigues, L.F.T.; Rosa, B.F.J.V.; Lobo, H.; Divino, A.C. \& Alves, R.G. 2015. Diversity and distribution of oligochaetes in tropical forested streams, southeastern Brazil. Journal of Limnology, 74: 433-443. 
Rodriguez, P. \& Reynoldson, T.B. 2011. The pollution biology of aquatic oligochaetes. New York, Springer Science \& Business Media.

Sambugar, B. 2007. Oligochetes from Alpine springs: a review. In: Cantonati M.; Bertuzzi, E. \& Spitale, D. (Eds.). The spring habitat: biota and sampling methods. Trento, Museo Tridentino di Scienze Naturali. p. 185-192.

Wetzel, M.J.; Fend, S.V.; Coates, K.A.; Kathman, R.D. \& Gelder, S.R. 2006. Taxonomy, systematics, and ecology of the aquatic Oligochaeta and Branchiobdellidae (Annelida, Clitcllata) of North America, with emphasis on the fauna occurring in Florida. A workbook. 10 September. Illinois Natural History Survey, Champaign.

Wetzel, M.J.; Kathman, R.D.; Fend, S.V. \& Coates, K.A. 2007. Classification and Checklist of the Freshwater Oligochaeta occurring in North America North of Mexico. Available at: http://wwn.inhs.illinois.edu/ mjwetzel/ FWOligoNAChklst.html. Access in: 15/02/2017.

\section{SUPPLEMENTARY MATERIAL}

\section{Additional Supporting Information may be found in the online version of this article:}

This list contains all the references consulted and utilized to obtain the data in the article "Global panorama of studies about freshwater oligochaetes: main trends and gaps".

- The list of SciELO contains references found only in this database (7 references).

- The list of Web of Science contains references found only in this database (351 references).

- The list of Scopus contains references found in this database and those that were common with the SciELO or Web of Science bases (621 references). 


\section{SCIELO}

Armendáriz, L.C. 2007. Efectos de la temperatura sobre el crecimiento individual y formación de zooides en Stylaria lacustris (Linnaeus, 1767) (Oligochaeta, Naididae). Biota Neotropica, 7: 77-81.

Christoffersen, M.L. 2010. Continental biodiversity of South American oligochaetes: The importance of inventories. Acta Zoológica Mexicana, 26: 35-46.

Corbi, J.J.; Jancso, M.A.; Strixino, S.T. \& Fragoso, E.N. 2004. Occurence of Oligochaeta living on larvae of Odonata from Ipeúna (São Paulo state, Brazil). Biota Neotropica, 4: 1-3.

Cortelezzi, A.; Armendáriz, L.C.; López van Oosterom, M.V.; Cepeda, R. \& Capítulo, A.R. 2012. Different levels of taxonomic resolution in bioassessment: a case study of Oligochaeta in lowland streams. Acta Limnologica Brasiliensia, 23: 412-425.

Fujita, D.S.; Takeda, A.M.; Coutinho, R. \& Fernandes, F.C. 2015. Influence of antifouling paint on freshwater invertebrates (Mytilidae, Chironomidae and Naididae): density, richness and composition. Brazilian Journal of Biology, 75: 70-78.

Pamplin, P.A.Z.; Rocha, 0. \& Marchese, M. 2005. Riqueza de espécies de Oligochaeta (Annelida, Clitellata) em duas represas do Rio Tietê (São Paulo). Biota Neotropica, 5: 63-70.

Righi, G. \& Hamoui, V. 2002. Oligochaeta, Naididae of the West Indies and adjacent regions. Papéis Avulsos de Zoologia, 42: 119-167.

\section{WEB OF SCIENCE}

Achurra, A., Rodriguez, P. \& Erseus, C. 2015. Pseudo-cryptic speciation in the subterranean medium: A new species of Stylodrilus Claparede, 1862, with a revision of the status of Bichaeta Bretscher, 1900 (Annelida, (litellata, Lumbriculidae). Zoologischer Anzeiger, 257, 71-86.

Agbo, S.0., Keinanen, M., Keski-Saari, S., Lemmetyinen, J., Akkanen, J., Leppanen, M.T., Mayer, P. \& Kukkonen, J.V.K. 2013a. Changes in Lumbriculus variegatus metabolites under hypoxic exposure to benzo(a)pyrene, chlorpyrifos and pentachlorophenol: Consequences on biotransformation. Chemosphere, 93(2), 302-310.

Agbo, S.0., Lemmetyinen, J., Keinanen, M., Keski-Saari, S., Akkanen, J., Leppanen, M.T., Wang, Z.X., Wang, H.L., Price, D.A. \& Kukkonen, J.V.K. 2013b. Response of Lumbriculus variegatus transcriptome and metabolites to model chemical contaminants. Comparative Biochemistry and Physiology - Part C: Toxicology and Pharmacology, 157(2), 183-191.

Ahamed, M.T. \& Mollah, M.F.A. 1992. Effects of various levels of wheat bran and mustard oil cake in the culture media on tubificid production. Aquaculture, 107(1), 107-113.

Akinschina, T.V. \& Snimschikova, L.N. 1991. Isochaetides-werestschagini sp. nov. (Oligachaeta, Tubificidae). Zoologichesky Zhurnal, 70(7), 130-132.

Anlauf, A. 1990. Cyst formation of Tubifex tubifex (Müller) - an adaptation to survive food deficiency and drought. Hydrobiologia, 190(1), 79-82.

Anlauf, A. \& Neumann, D. 1997. The genetic variability of Tubifex tubifex (Müller) in 20 populations and its relation to habitat type. Archiv Fur Hydrobiologie, 139(2), 145-162.

Anlauf, K.J. \& Moffitt, C.M. 2008. Models of stream habitat characteristics associated with tubificid populations in an intermountain watershed. Hydrobiologia, 603, 147-158

Anlauf, K.J. \& Moffitt, C.M. 2010. Modelling of landscape variables at multiple extents to predict fine sediments and suitable habitat for Tubifex tubifex in a stream system. Freshwater Biology, 55(4), 794-805.
Anschutz, P., Ciutat, A., Lecroart, P., Gerino, M. \& Boudou, A. 2012. Effects of Tubificid Worm Bioturbation on Freshwater Sediment Biogeochemistry. Aquatic Geochemistry, 18(6), 475-497.

Arendarczyk, A., Jakubowska, A., Zgorska, A. \& Grabinska-Sota, E. 2014. Toxic effects of cadmium-spiked sediments in Tubifex tubifex: enzyme biomarkers measurements. Desalination and Water Treatment, 52(19-21), 3798-3803.

Armendariz, L.C. 2000. Population dynamics of Stylaria lacustris (Linnaeus, 1767) (Oligochaeta, Naididae) in Los Talas, Argentina. Hydrobiologia, 438(1-3), 217-226.

Arsan, E.L., Hallett, S.L. \& Bartholomew, J.L. 2007. Tubifex tubifex from Alaska and their susceptibility to Myxobolus cerebralis. Journal of Parasitology, 93(6), 1332-1342

Artola-Garicano, E., Sinnige, T.L., van Holsteijn, I., Vaes, W.H.J. \& Hermens, J.L.M. 2003. Bioconcentration and acute toxicity of polycyclic musks in two benthic organisms (Chironomus riparius and Lumbriculus variegatus). Environmental Toxicology and Chemistry, 22(5), 1086-1092.

Atanackovic, A., Sporka, F., Tomovic, J., Vasiljevic, B., Markovic, V., Simic, V. \& Paunovic, M. 2012. First record of Bothrioneurum vejdovskyanum Štolc, 1886 (Oligochaeta, Tubificidae) in Serbia. Archives of Biological Sciences, 64(3), 1123-1126.

Back, H. 1990. Epidermal uptake of $P B, C D$, and $Z N$ in Tubificid worms. Oecologia, 85(2), 226-232.

Back, H. \& Prosi, F. 1985. Distribution of inorganic cations in Limnodrilus udekemianus (Oligochaeta, Tubificidae) using laser-induced microprobe mass analysis, with special emphasis on heavy-metals. Micron and Microscopica Acta, 16(3), 145-150.

Basim, Y., Farzadkia, M., Jaafarzadeh, N. \& Hendrickx, T. 2012. Sludge reduction by Lumbriculus variegatus in Ahvas wastewater treatment plant. Iranian Journal of Environmental Health Science \& Engineering, 9.

Baturina, M., Timm, T. \& Loskutova, 0. 2014. Oligochaete (Annelida, Clitellata) communities in lakes of the Ural Mountains (Russia), in Pinder, A., Arslan, N. \& Wetzel, M. (Eds.). Proceedings of the $12^{\text {th }}$ International Symposium on Aquatic Oligochaeta, Zoosymposia, 77-94.

Beauchamp, K.A., Kelley, G.O., Nehring, R.B. \& Hedrick, R.P. 2005. The severity of whirling disease among wild trout corresponds to the differences in genetic composition of Tubifex tubifex populations in central Colorado. Journal of Parasitology, 91(1), 53-60.

Beaudet, J.F., Prevost, M., Niquette, P., Clement, B., Coallier, J. \& Arcouette, N. 2000. Simple methods for evaluating the population of naidids in drinking water treatment plants. Canadian Journal of Civil Engineering, 27(4), 601-609.

Beckett, D.C., Aartila, T.P. \& Miller, A.C. 1992. Seasonal change in plantdwelling Chironomidae and Naididae in a Wisconsin Lake. Journal of Freshwater Ecology, 7(1), 45-57.

Beckingham, B. \& Ghosh, U. 2010. Comparison of field and laboratory exposures of Lumbriculus variegatus to polychlorinated biphenylimpacted river sediments. Environmental Toxicology and Chemistry, 29(12), 2851-2858.

Belden, J.B., Lotufo, G.R. \& Lydy, M.J. 2005. Accumulation of hexahydro1,3,5-trinitro-1,3,5-triazine in channel catfish (Ictalurus punctatus) and aquatic oligochaetes (Lumbriculus variegatus). Environmental Toxicology and Chemistry, 24(8), 1962-1967.

Bely, A.E. \& Wray, G.A. 2004. Molecular phylogeny of naidid worms (Annelida: (litellata) based on cytochrome oxidase I. Molecular Phylogenetics and Evolution, 30(1), 50-63.

Bervoets, L., Blust, R., deWit, M. \& Verheyen, R. 1997. Relationships between river sediment characteristics and trace metal concentrations in Tubificid worms and chironomid larvae. Environmental Pollution, 95(3), 345-356. 
Bettinetti, R. \& Provini, A. 2002. Toxicity of 4-nonylphenol to Tubifex tubifex and Chironomus riparius in 28-day whole-sediment tests. Ecotoxicology and Environmental Safety, 53(1), 113-121.

Blazer, V.S., Waldrop, T.B., Schill, W.B., Densmore, C.L. \& Smith, D. 2003. Effects of water temperature and substrate type on spore production and release in eastern Tubifex tubifex worms infected with Myxobolus cerebralis. Journal of Parasitology, 89(1), 21-26.

Bonacina, C., Bonomi, G. \& Monti, C. 1989a. Density-dependent processes in cohorts of Tubifex tubifex, with special emphasis on the control of fecundity. Hydrobiologia, 180, 135-141.

Bonacina, C., Bonomi, G. \& Monti, C. 1989b. Population analysis in masscultures of Tubifex tubifex. Hydrobiologia, 180, 127-134.

Bonacina, C., Pasteris, A., Bonomi, G. \& Marzuoli, D. 1994. Quantitative observations on the population ecology of Branchiura sowerbyi (Oligochaeta, Tubificidae). Hydrobiologia, 278(1-3), 267-274.

Bonacina, C., Pasteris, A., DiCola, G. \& Bonomi, G. 1996. Production and population dynamics of Tubifex tubifex in the profundal zone of a freshwater reservoir in N Italy. Hydrobiologia, 334(1-3), 141-146.

Bouche, M.L., Arnoult, F. \& Vernet, G. 2003. Caudal regeneration in Tubifex tubifex (Oligochaeta, Tubificidae) following copper exposure. Invertebrate Biology, 122(1), 42-51.

Bouche, M.L., Biagianti-Risbourg, S. \& Vernet, G. 1999. A light and scanning electron microscope study of the morphology of the chaetae of Tubifex tubifex in a non-polluted medium. Hydrobiologia, 411, 39-44.

Bouche, M.L., Habets, F., Biagianti-Risbourg, S. \& Vernet, G. 2000. Toxic effects and bioaccumulation of cadmium in the aquatic oligochaete Tubifex tubifex. Ecotoxicology and Environmental Safety, 46(3), 246-251.

Brinkhurst, R.0. 1985a. The generic and subfamilial classification of the Naididae (Annelida, Oligochaeta). Proceedings of the Biological Society of Washington, 98(2), 470-475.

Brinkhurst, R.0. 1985b. Varichaetadrilus-minutus (Brinkhurst, 1965) new combination for psammoryctides, minutus (Oligochaeta, Tubificidae). Proceedings of the Biological Society of Washington, 98(3), 655-656.

Brinkhurst, R.O. 1987. Notes on Varichaetadrilus Brinkhurst and Kathman, 1983 (Oligochaeta, Tubificidae). Proceedings of the Biological Society of Washington, 100(3), 515-517.

Brinkhurst, R.0. 1989a. A phylogenetic analysis of the Lumbriculidae (Annelida, Oligochaeta). Canadian Journal of Zoology, 67(11), 2731-2739.

Brinkhurst, R.0. 1989b. Varichaetadrilus-angustipenis Brinkhurst \& Cook, 1966), new combination for Limnodrilus angustipenis (Oligochaeta, Tubificidae). Proceedings of the Biological Society of Washington, 102(2), 311-312.

Brinkhurst, R.0. 1991. A phylogenetic analysis of the Tubificinae (Oligochaeta, Tubificidae). (anadian Journal of Zoology, 69(2), 392-397.

Brinkhurst, R.0. \& Barbour, M.T. 1985. A new species of Aulodrilus Bretscher (Oligochaeta, Tubificidae) from North America. Proceedings of the Biological Society of Washington, 98(4), 931-934.

Brinkhurst, R.0. \& Coates, K.A. 1985. The genus paranais (Oligochaeta, Naididae) in North America. Proceedings of the Biological Society of Washington, 98(2), 303-313.

Brinkhurst, R.O. \& Diaz, R.J. 1985. Isochaetides columbiensis, new species (Oligochaeta, Tubificidae) from the Columbia River, Oregon. Proceedings of the Biological Society of Washington, 98(4), 949-953.

Brinkhurst, R.0. \& Marchese, M. 1987. A contribution to the taxonomy of the aquatic Oligochaeta (Haplotaxidae, Phreodrilidae, Tubificidae) of South America. Canadian Journal of Zoology - Revue Canadienne de Zoologie, 65(12), 3154-3165.

Brinkhurst, R.O., Rodriguez, P., Chon, T.S. \& Kwon, T.S. 1994. A new genus of Lumbriculidae (Oligochaeta) from Korea. Canadian Journal of Zoology Revue Canadienne de Zoologie, 72(11), 1960-1966.
Bunke, D. 2003. Early development of metanephridia in the caudal budding zone of a clitellate annelid, Dero digitata (Naidida): an electronmicroscopical study. Acta Zoologica, 84(2), 87-97.

Burkhard, L.P., Hubin-Barrows, D., Billa, N., Highland, T.L., Hockett, J.R., Mount, D.R., Norberg-King, T.J., Hawthorne, S., Miller, D.J. \& Grabanski, C.B. 2015. Sediment Bioaccumulation Test with Lumbriculus variegatus: Effects of Feeding. Archives of Environmental Contamination and Toxicology, 68(4), 696-706.

Burkhard, L.P., Mount, D.R., Highland, T.L., Hockett, J.R., Norberg-King, T., Billa, N., Hawthorne, S.B., Miller, D.J. \& Grabanski, C.B. 2013. Evaluation of $P C B$ bioaccumulation by Lumbriculus variegatus in field-collected sediments. Environmental Toxicology and Chemistry, 32(7), 1495-1503.

Camusso, M., Polesello, S., Valsecchi, S. \& Vignati, D.A.L. 2012a. Importance of dietary uptake of trace elements in the benthic deposit-feeding Lumbriculus variegatus. TRAC - Trends in Analytical Chemistry, 36, 103-112.

Camusso, M., Polesello, S., Valsecchi, S. \& Vignati, D.A.L. 2012b. Importance of dietary uptake of trace elements in the benthic deposit-feeding Lumbriculus variegatus. TRAC - Trends in Analytical Chemistry, 36, 103-112.

Casellato, S., Covre, V. \& Del Piero, S. 2014. Effects of sodium fluoride on the gametogenesis of the tubificid oligochaete Branchiura sowerbyi Beddard, in Pinder, A., Arslan, N. \& Wetzel, M. (Eds.). Proceedings of the $12^{\text {th }}$ International Symposium on Aquatic Oligochaeta, Zoosymposia, 51-58.

Casellato, S., Martinucci, G. \& Zoja, E. 1987. Ultrastructural features of gametogenesis during the life-cycle in Branchiura sowerbyi Beddard (Oligochaeta, Tubificidae). Hydrobiologia, 155, 145-154.

Casellato, S. \& Negrisolo, P. 1989. Acute and chronic effects of an anionic surfactant on some fresh-water tubificid species. Hydrobiologia, 180, 243-252.

Chen, T., Furst, A. \& Chien, P.K. 1994. The effects of cadmium and iron on catalase activities in Tubifex. Journal of the American College of Toxicology, 13(2), 112-120.

Chuiko, G.M., Lapkina, L.N. \& Podgornaya, V.A. 2011. Substrate-inhibitory analysis of the cholinesterase in the freshwater oligochaete Lumbriculus variegatus (of Müller, 1773; Lumbriculidae, Oligochaeta). Biochemical Systematics and Ecology, 39(3), 169-174.

Ciutat, A., Gerino, M. \& Boudou, A. 2007. Remobilization and bioavailability of cadmium from historically contaminated sediments: Influence of bioturbation by Tubificids. Ecotoxicology and Environmental Safety, 68(1), 108-117.

Ciutat, A., Gerino, M., Mesmer-Dudons, N., Anschutz, P. \& Boudou, A. 2005. Cadmium bioaccumulation in Tubificidae from the overlying water source and effects on bioturbation. Ecotoxicology and Environmental Safety, 60(3), 237-246.

Ciutat, A., Weber, 0., Gerino, M. \& Boudou, A. 2006. Stratigraphic effects of Tubificids in freshwater sediments: a kinetic study based on X-Ray images and grain-size analysis. Acta Oecologica - International Journal of Ecology, 30(2), 228-237.

Coleman, J.G., Kennedy, A.J., Bednar, A.J., Ranville, J.F., Laird, J.G., Harmon, A.R., Hayes, C.A., Gray, E.P., Higgins, C.P., Lotufo, G. \& Steevens, J.A. 2013. Comparing the effects of nanosilver size and coating variations on bioavailability, internalization, and elimination, using Lumbriculus variegatus. Environmental Toxicology and Chemistry, 32(9), 2069-2077.

Coler, R.A., Coler, M.S. \& Kostecki, P.T. 1988. Tubificid behavior as a stress indicator. Water Research, 22(2), 263-267.

Contardo-Jara, V., Klingelmann, E. \& Wiegand, C. 2009. Bioaccumulation of glyphosate and its formulation Roundup Ultra in Lumbriculus variegatus and its effects on biotransformation and antioxidant enzymes. Environmental Pollution, 157(1), 57-63. 
Crisp, K.M., Grupe, R.E., Lobsang, T.T. \& Yang, X. 2010. Biogenic amines modulate pulse rate in the dorsal blood vessel of Lumbriculus variegatus. Comparative Biochemistry and Physiology - Part C: Toxicology and Pharmacology, 151(4), 467-472.

Crottini, A., Marotta, R., Barbuto, M., Casiraghi, M. \& Ferraguti, M. 2008. The world in a river? A preliminary analysis of the 165 rDNA variability of Tubifex species (Clitellata: Tubificidae) from the Lambro River. Molecular Phylogenetics and Evolution, 48(3), 1189-1203.

Cuadrado, S. \& Martinez-Ansemil, E. 2001. External structures used during attachment and sperm transfer in Tubificids (Annelida, Oligochaeta). Hydrobiologia, 463, 107-113.

Cui, Y.D., He, X.B., Peng, Y. \& Wang, H.Z. 2015. Records of Naididae and Lumbriculidae (Clitellata) from Tibet, China, with description of a new species of Nais. Zootaxa, 3956(4), 513-530.

Dawson, T.D., Lott, K.G., Leonard, E.N. \& Mount, D.R. 2003. Time course of metal loss in Lumbriculus variegatus following sediment exposure. Environmental Toxicology and Chemistry, 22(4), 886-889.

Deeguileor, M., Lanzavecchia, G., Valvassori, R. \& Lanzavecchia, P. 1987. Unusual model of lumbriculids helical muscles - comparison with body wall muscles in other microdriles. Hydrobiologia, 155, 135-144.

Del Piero, S., Masiero, L. \& Casellato, S. 2014. Toxicity and bioaccumulation of fluoride ion on Branchiura sowerbyi, Beddard, (Oligochaeta, Tubificidae), in Pinder, A., Arslan, N. \& Wetzel, M. (Eds.). Proceedings of the $12^{\text {th }}$ International Symposium on Aquatic Oligochaeta, Zoosymposia, 44-50.

Delmotte, S., Meysman, F.J.R., Ciutat, A., Boudou, A., Sauvage, S. \& Gerino, M. 2007. Cadmium transport in sediments by tubificid bioturbation: An assessment of model complexity. Geochimica et Cosmochimica Acta, 71(4), 844-862.

Dermott, R. \& Munawar, M. 1992. A simple and sensitive assay for evaluation of sediment toxicity using Lumbriculus variegatus (Müller). Hydrobiologia, 235, 407-414.

Di Chiara, A.P., Pagani, M. \& Leoni, B. 1999. Enzymatic variability in sympatric species of Tubifex (Clitellata: Tubificidae). Hydrobiologia, 406, 83-86.

Di, S.S., Liu, T.T., Diao, J.L. \& Zhou, Z.Q. 2013. Enantioselective bioaccumulation and degradation of sediment-associated metalaxyl enantiomers in Tubifex tubifex. Journal of Agricultural and Food Chemistry, 61(21), 4997-5002.

Dierickx, P.J. 1985. Anionic and neutral glutathione s-transferase isoenzymes in the fresh-water worm Tubifex tubifex (OFM). Archives Internationales de Physiologie de Biochimie et de Biophysique, 93(3), 193-198.

Dolidze, T.M. 1994. Biology of Limnodrilus claparedeanus ratzel (Oligochaeta, Tubificidae) in the Tsimlyansk Reservoir. Hydrobiologia, 278(1-3), 275-279.

Drewes, C.D. 1999. Helical swimming and body reversal behaviors in Lumbriculus variegatus (Annelida: Clitellata: Lumbriculidae). Hydrobiologia, 406, 263-269.

Drewes, C.D. \& Brinkhurst, R.O. 1990. Giant nerve-fibers and rapid escape reflexes in newly hatched aquatic oligochaetes, Lumbriculus variegatus (family Lumbriculidae). Invertebrate Reproduction \& Development, 17(2), 91-95.

Drewes, C.D. \& Fourtner, C.R. 1989. Hindsight and rapid escape in a freshwater oligochaete. Biological Bulletin, 177(3), 363-371.

Drewes, C.D. \& Fourtner, C.R. 1990. Morphallaxis in an aquatic oligochaete, Lumbriculus variegatus - reorganization of escape reflexes in regenerating body fragments. Developmental Biology, 138(1), 94-103.

Drewes, C.D. \& Fourtner, C.R. 1993. Helical swimming in a fresh-water oligochaete. Biological Bulletin, 185(1), 1-9.

Drewes, C.D. \& Zoran, M.J. 1989. Neuro-behavioral specializations for respiratory movements and rapid escape from predators in posterior segments of the tubificid Branchiura sowerbyi. Hydrobiologia, 180, 65-71.
DuBey, R. \& Caldwell, C. 2004. Distribution of Tubifex tubifex lineages and Myxobolus cerebralis infection in the tailwater of the San Juan River, New Mexico. Journal of Aquatic Animal Health, 16(4), 179-185.

DuBey, R., Caldwell, C. \& Gould, W.R. 2005. Effects of temperature, photoperiod, and Myxobolus cerebralis infection on growth, reproduction, and survival of Tubifex tubifex lineages. Journal of Aquatic Animal Health, 17(4), 338-344.

DuBey, R.J. 2008. Genetic differentiation of lineages of Tubifex tubifex from the San Juan River, New Mexico. Southwestern Naturalist, 53(2), 268-272.

Ducrot, V., Pery, A.R.R., Queau, H., Mons, R., Lafont, M. \& Garric, J. 2007. Rearing and estimation of life-cycle parameters of the tubicifid worm Branchiura sowerbyi: Application to ecotoxicity testing. Science of the Total Environment, 384(1-3), 252-263.

Dumnicka, E. 1986. Amsterdam expeditions to the west-indian-islands. 50. Naididae (Oligochaeta) from subterranean waters of west-indian-islands - distribution, taxonomic remarks and description of a new species. Bijdragen Tot De Dierkunde, 56(2), 267-281.

Eckroth, M.C. \& Brinkhurst, R.0. 1996. Tenagodrilus musculus, a new genus and species of Lumbriculidae (Clitellata) from a temporary pond in Alabama, USA. Hydrobiologia, 334(1-3), 1-9.

Edwards, P.A. \& Simkiss, K. 2005. Dietary influences on the bioaccumulation of pollutants by the annelid, Lumbriculus variegatus: Experiments comparing artificial particles and natural sediments. Bulletin of Environmental Contamination and Toxicology, 74(2), 328-334.

Egeler, P., Rombke, J., Meller, M., Knacker, T., Franke, C., Studinger, G. \& Nagel, R. 1997. Bioaccumulation of lindane and hexachlorobenzene by tubificid sludgeworms (Oligochaeta) under standardised laboratory conditions. Chemosphere, 35(4), 835-852.

Egeler, P., Rombke, J., Meller, M., Knacker, T. \& Nagel, R. 1999. Bioaccumulation test with Tubificid Sludgeworms in artificial media - development of a standardisable method. Hydrobiologia, 406, 271-280.

Elwell, L.C.S., Kerans, B.L. \& Zickovich, J. 2009. Host-parasite interactions and competition between tubificid species in a benthic community. Freshwater Biology, 54(8), 1616-1628.

Envall, I., Erseus, C. \& Gustavsson, L.M. 2008. Ultrastructural investigation of coelomocytes in representatives of Naidinae and Rhyacodrilinae (Annelida, Clitellata, Tubificidae). Journal of Morphology, 269(9), 1157-1167.

Envall, I., Gustavsson, L.M. \& Erseus, C. 2012. Genetic and chaetal variation in Nais worms (Annelida, Clitellata, Naididae). Zoological Journal of the Linnean Society, 165(3), 495-520.

Envall, I., Kallersjo, M. \& Erseus, C. 2006. Molecular evidence for the nonmonophyletic status of Naidinae (Annelida, Clitellata, Tubificidae). Molecular Phylogenetics and Evolution, 40(2), 570-584.

Erseus, C. 1999. Parvidrilus strayeri, a new genus and species, an enigmatic interstitial clitellate from underground waters in Alabama. Proceedings of the Biological Society of Washington, 112(2), 327-337.

Erseus, C. \& Dumnicka, E. 1988. A new Phallodrilus (Oligochaeta, Tubificidae) from subterranean waters in central Italy. Stygologia, 4, 116-120.

Erseus, C. \& Gustavsson, L. 2002. A proposal to regard the former family Naididae as a subfamily within Tubificidae (Annelida, Clitellata). Hydrobiologia, 485(1-3), 253-256.

Erseus, C., Kallersjo, M., Ekman, M. \& Hovmoller, R. 2002. 18S rDNA phylogeny of the Tubificidae (Clitellata) and its constituent taxa: Dismissal of the Naididae. Molecular Phylogenetics and Evolution, 22(3), 414-422.

Erseus, C., Prestegaard, T. \& Kallersjo, M. 2000. Phylogenetic analysis of Tubificidae (Annelida, Clitellata) based on 185 rDNA sequences. Molecular Phylogenetics and Evolution, 15(3), 381-389.

Famme, P. \& Knudsen, J. 1985. Anoxic survival, growth and reproduction by the fresh-water annelid, Tubifex sp., demonstrated using a new simple 
anoxic chemostat. Comparative Biochemistry and Physiology - Part A: Physiology, 81(2), 251-253.

Farara, D.G. \& Erseus, C. 1991. Phallodrilus-aquaedulcis hrabe, 1960, a meiobenthic fresh-water oligochaete (Tubificidae) previously known only from Europe, recorded from the Niagara River, North America. Canadian Journal of Zoology - Revue Canadienne de Zoologie, 69(2), 291-294.

Fargasova, A. 1994. Toxicity of metals on Daphnia magna and Tubifex tubifex. Ecotoxicology and Environmental Safety, 27(2), 210-213.

Fargasova, A. 1997. Determination of toxicity of plant growth regulators in selected aquatic organisms Daphnia magna and Tubifex tubifex. Biologia, 52(3), 405-408.

Fargasova, A. 1998. Comparative acute toxicity of $\mathrm{Cu} 2+, \mathrm{Cu}+, \mathrm{Mn2}+, \mathrm{Mo6}+$, $\mathrm{Ni} 2+$ and $\mathrm{V} 5+$ to Chironomus plumosus larvae and Tubifex tubifex worms. Biologia, 53(3), 315-319.

Fargasova, A. \& Kizlink, J. 1996. Acute toxic effects of organotin compounds on benthic organisms: Tubifex tubifex and Chironomus plumosus. Biologia, 51(6), 677-681.

Fend, S.V. 2005. A review of the genus Eclipidrilus (Annelida: Clitellata: Lumbriculidae), with description of a new species from western North America. Zootaxa, (969), 1-42.

Fend, S.V. \& Gustafson, D.L. 2001. A new Lumbriculid genus and species from North America (Clitellata, Lumbriculidae). Hydrobiologia, 463, 13-22.

Fend, S.V. \& Lenat, D.R. 2007. Two new genera of Lumbriculidae (Annelida, Clitellata) from North Carolina, USA. Zootaxa, (1666), 1-22.

Fend, S.V. \& Ohtaka, A. 2004. Yamaguchia toyensis sp. nov., gen. nov. (Annelida, Clitellata, Lumbriculidae) from profundal lake habitat in Japan. Zoological Science, 21(6), 677-683.

Ferraguti, M., Bondi, M. \& Lanzavecchia, S. 1991. Ultrastructural analysis of sperm flagella in 2 clitellates (Annelida), plasma-membrane and periaxonemal area. Tissue \& (ell, 23(4), 537-546.

Ferraguti, M., Grassi, G. \& Erseus, C. 1989. Different models of tubificid spermatozeugmata. Hydrobiologia, 180, 73-82.

Ferraguti, M. \& Jamieson, B.G.M. 1987. Spermiogenesis in bythonomuslemani and the phylogenetic position of the Lumbriculidae (Oligochaeta, Annelida). Hydrobiologia, 155, 123-134.

Ferraguti, M. \& Ruprecht, D. 1992. The double sperm line in the tubificid Clitellio arenarius (Annelida, Oligochaeta). Bollettino di Zoologia, 59(4), 349-362.

Ferraguti, M., Ruprecht, D., Erseus, C. \& Giere, 0. 1994. An ultrastructural overview of tubificid spermatozoa. Hydrobiologia, 278(1-3), 165-178.

Finogenova, N.P. 1986. Diagnostic characters of subfamilies in the family Tubificidae (0ligochaeta). Zoologichesky Zhurnal, 65(2), 194-202.

Fischer, E. \& Molnar, L. 1986. 3 Discrete stages of the nuclear volume alterations of the chloragocytes in experimentally treated Limnodrilus hoffmeisteri (Oligochaeta, Tubificidae). Zoologischer Anzeiger, 216(1-2), 99-108.

Fischer, E. \& Molnar, L. 1987. Karyometrical evidences of the role of chloragocytes in the salt balance mechanisms of the tubificid worm Limnodrilus hoffmeisteri. Zoologischer Anzeiger, 218(5-6), 374-378.

Fischer, E., Molnar, L. \& Szucs, I. 1986. Possible reasons for chloragocyte nuclear swelling under hypoxic conditions and under saline load in the tubificid worm Limnodrilus hoffmeisteri. Zoologischer Anzeiger, 217(3-4), 283-288.

Fukuhara, H., Ohtaka, A., Isobe, Y. \& Sakamoto, M. 1987. Seasonal-changes in vertical-distribution, biomass and fecal production of Tubificids in the profundal region of a shallow japanese lake. Holarctic Ecology, 10(1), 8-13.

Fukuhara, H. \& Sakamoto, M. 1987. Enhancement of inorganic nitrogen and phosphate release from lake sediment by Tubificid worms and chironomid larvae. Oikos, 48(3), 312-320.
Gainutdinov, M.K., Yargunov, V.G., Kalinnikova, T.B., Gainutdinov, T.M. \& Varlamov, V.E. 2000. On the role of a decentralized control system in adaptation to high ambient temperature in a population of the oligochaete Tubifex tubifex. Russian Journal of Ecology, 31(6), 444-446.

Galluba, S., Oetken, M.\& Oehlmann, J.2012. Comprehensive sediment toxicity assessment of Hessian surface waters using Lumbriculus variegatus and Chironomus riparius. Journal of Environmental Science and Health Part A: Toxic/Hazardous Substances \& Environmental Engineering, 47(4), 507-521.

Geta, R., Postolache, C. \& Vadineanu, A. 2004. Ecological significance of nitrogen cycling by tubificid communities in shallow eutrophic lakes of the Danube Delta. Hydrobiologia, 524(1), 193-202.

Giani, N., Erseus, C. \& Martinezansemil, E. 1990. Redefinition of the subterranean genus Krenedrilus Dumnicka (Oligochaeta, Tubificidae) with a redescription of Krenedrilus papillatus Dumnicka, 1983 and the description of 2 new species. Stygologia, 5(1), 55-65.

Giani, N. \& Rodriquez, P. 1988. Description of some new species of Tubificidae (Oligochaeta) from caves and karstic springs of the Iberian Peninsula. Stygologia, 4, 121-137.

Gillis, P.L., Dixon, D.G., Borgmann, U. \& Reynoldson, T.B. 2004a. Uptake and depuration of cadmium, nickel, and lead in laboratory-exposed Tubifex tubifex and corresponding changes in the concentration of a metallothionein-like protein. Environmental Toxicology and Chemistry, 23(1), 76-85.

Gillis, P.L., Reynoldson, T.B. \& Dixon, D.G. 2004b. Natural variation in a metallothionein-like protein in Tubifex tubifex in the absence of metal exposure. Ecotoxicology and Environmental Safety, 58(1), 22-28.

Goto, A., Kitamura, K., Arai, A. \& Shimizu, T. 1999a. Cell fate analysis of teloblasts in the Tubifex embryo by intracellular injection of HRP. Development Growth \& Differentiation, 41(6), 703-713.

Goto, A., Kitamura, K. \& Shimizu, T. 1999b. Cell lineage analysis of pattern formation in the Tubifex embryo. I. Segmentation in the mesoderm. International Journal of Developmental Biology, 43(4), 317-327.

Guerin, C. \& Giani, N. 1996. Analytical study of the locomotor and respiratory movements of Tubificid worms by means of video recording. Hydrobiologia, 333(1), 63-69.

Gunn, A.M., Hunt, D.T.E. \& Winnard, D.A. 1989. The effect of heavymetal speciation in sediment on bioavailability to Tubificid worms. Hydrobiologia, 188, 487-496.

Guo, X.S., Liu, J.X., Wei, Y.S. \& Li, L. 2007. Sludge reduction with Tubificidae and the impact on the performance of the wastewater treatment process. Journal of Environmental Sciences, 19(3), 257-263.

Gustafsson, D.R., Price, D.A. \& Erseus, C. 2009. Genetic variation in the popular lab worm Lumbriculus variegatus (Annelida: Clitellata: Lumbriculidae) reveals cryptic speciation. Molecular Phylogenetics and Evolution, 51(2), 182-189.

Gutierrez, R.M.P. \& Reyes, I.C. 2006. Sterols isolated from Tubifex tubifex. Natural Product Research, 20(13), 1271-1276.

Hall, S., Lockwood, R. \& Harrass, M.C. 2014. Application of a unique test design to determine the chronic toxicity of boron to the aquatic worm Lumbriculus variegatus and Fatmucket mussel lampsilis siliquoidea. Archives of Environmental Contamination and Toxicology, 66(1), 58-68.

Hamilton, A.J. \& Canning, E.U. 1987. Studies on the proposed role of Tubifex tubifex (Müller) as an intermediate host in the life-cycle of Myxosoma-cerebralis (Hofer, 1903). Journal of Fish Diseases, 10(3), 145-151.

Harman, W.J., Brinkhurst, R.0. \& Marchese, M. 1988. A contribution to the taxonomy of the aquatic Oligochaeta (Naididae) of South America. Canadian Journal of Zoology - Revue Canadienne de Zoologie, 66(10), 2233-2242. 
Hartmann, N.B., Legros, S., Von der Kammer, F., Hofmann, T. \& Baun, A. 2012. The potential of Ti02 nanoparticles as carriers for cadmium uptake in Lumbriculus variegatus and Daphnia magna. Aquatic Toxicology, 118, $1-8$.

He, X.B., Cui, Y.D. \& Wang, H.Z. 2012. Two new species of Tubificinae (Annelida: Clitellata: Naididae) from Tibet, China. Zootaxa, (3458), 159-165.

Hessling, R., Müller, M.C. \& Westheide, W. 1999. CLSM analysis of serotoninimmunoreactive neurons in the central nervous system of Nais variabilis, Slavina appendiculata and Stylaria lacustris (Oligochaeta: Naididae). Hydrobiologia, 406, 223-233.

Higgins, C.P., Paesani,Z.J., Chalew, T.E.A.\& Halden, R.U. 2009. Bioaccumulation of triclocarban in Lumbriculus variegatus. Environmental Toxicology and Chemistry, 28(12), 2580-2586.

Hirabayashi, K., Oga, K. \& Yamamoto, M. 2014. Bathymetric distribution of aquatic Oligochaeta in Lake Kizaki, Central Japan, in Pinder, A., Arslan, N. \& Wetzel, M. (Eds.). Proceedings of the $12^{\text {th }}$ International Symposium on Aquatic Oligochaeta, Zoosymposia, 36-43.

Hirsch, M.P. 1998. Bioaccumulation of silver from laboratory-spiked sediments in the oligochaete (Lumbriculus variegatus). Environmental Toxicology and Chemistry, 17(4), 605-609.

Hoover, J.J. \& Lodes, M.J. 1986. Chaetogaster limnaei (Oligochaeta, Naididae) in Oklahoma. Southwestern Naturalist, 31(4), 542-544.

Huang, X., Liang, P. \& Qian, Y. 2007. Excess sludge reduction induced by Tubifex tubifex in a recycled sludge reactor. Journal of Biotechnology, 127(3), 443-451.

Ingersoll, C.G., Brunson, E.L., Wang, N., Dwyer, E.J., Ankley, G.T., Mount, D.R., Huckins, J., Petty, J. \& Landrum, P.E. 2003. Uptake and depuration of nonionic organic contaminants from sediment by the oligochaete, Lumbriculus variegatus. Environmental Toxicology and Chemistry, 22(4), 872-885.

Ishii, R. \& Shimizu, T. 1995. Unequal first cleavage in the Tubifex egg involvement of a monastral mitotic apparatus. Development Growth \& Differentiation, 37(6), 687-701.

Ishii, R. \& Shimizu, T. 1997a. Equalization of unequal first cleavage in the Tubifex egg by introduction of an additional centrosome: Implications for the absence of cortical mechanisms for mitotic spindle asymmetry. Developmental Biology, 189(1), 49-56.

Ishii, R. \& Shimizu, T. 1997b. Reproductive capability of maternal centrosomes in the Tubifex egg. Zoological Science, 14(6), 961-968.

Jantunen, A.P.K., Tuikka, A., Akkanen, J. \& Kukkonen, J.V.K. 2008. Bioaccumulation of atrazine and chlorpyrifos to Lumbriculus variegatus from lake sediments. Ecotoxicology and Environmental Safety, 71(3), 860-868.

Jordan, M. 1986. Tubifex bioassay test in studies on the pyrethroid decis 2.5 EC. Folia Biologica-Krakow, 34(4), 393-397.

Juget, J., Chatelliers, M.C.D. \& Rodriguez, P. 2006. Troglodrilus (Annelida, Oligochaeta, Tubificidae), a new genus from subterranean habitats in southwestern Europe. Hydrobiologia, 564(1), 7-17.

Kaeser, A.J. \& Sharpe, W.E. 2008. The ecology of Tubifex tubifex in two Myxobolus cerebralis enzootic streams in Pennsylvania. Journal of Freshwater Ecology, 23(4), 575-588.

Kaiser, M., Irmer, U. \& Weiler, K. 1989. Monitoring of water-quality seasonal-variations of heavy-metals in sediment, suspended particulate matter and Tubificids of the Elbe River. Environmental Technology Letters, 10(9), 845-854

Kajak, Z. \& Prus, P. 2004. Influence of the population density and the amount of food on Chironomus plumosus (L.) and Tubificidae. Laboratory experiments. Polish Journal of Ecology, 52(1), 47-53.

Kalinnikova, T.B., Gainutdinov, T.M., Seraziev, R.K. \& Gainutdinov, M.K. 2003. The effect of ambient temperature on intraspecific interactions controlling heat tolerance in the oligochaetes Enchytraeus albidus and Tubifex tubifex. Russian Journal of Ecology, 34(3), 198-201.

Kaonga, C.C., Kumwenda, J. \& Mapoma, H.T. 2010. Accumulation of lead, cadmium, manganese, copper and zinc by sludge worms; Tubifex tubifex in sewage sludge. International Journal of Environmental Science \& Technology, 7(1), 119-126.

Kathman, R.D. 1985. Synonymy of Pristinella jenkinae (Oligochaeta, Naididae). Proceedings of the Biological Society of Washington, 98(4), 1022-1027.

Kaygorodova, I.A., Sherbakov, D.Y. \& Martin, P. 2007. Molecular phylogeny of Baikalian Lumbriculidae (Oligochaeta): evidence for recent explosive speciation. Comparative Cytogenetics, 1(1), 71-84.

Keilty, T.J., White, D.S. \& Landrum, P.F. 1988. Sublethal responses to endrin in sediment by Stylodrilus heringianus (Lumbriculidae) as measured by a 137 cesium marker layer technique. Aquatic Toxicology, 13(3), 251-270.

Kerans, B.L., Rasmussen, C., Stevens, R., Colwell, A.E.L. \& Winton, J.R. 2004. Differential propagation of the metazoan parasite Myxobolus cerebralis by Limnodrilus hoffmeisteri, llyodrilus templetoni, and genetically distinct strains of Tubifex tubifex. Journal of Parasitology, 90(6), 1366-1373.

Kerans, B.L., Stevens, R.I. \& Lemmon, J.C. 2005. Water temperature affects a host-parasite interaction: Tubifex tubifex and Myxobolus cerebralis. Journal of Aquatic Animal Health, 17(3), 216-221.

Khan, F.R., Paul, K.B., Dybowska, A.D., Valsami-Jones, E., Lead, J.R., Stone, V. \& Fernandes, T.F. 2015. Accumulation dynamics and acute toxicity of silver nanoparticles to Daphnia magna and Lumbriculus variegatus: Implications for metal modeling approaches. Environmental Science \& Technology, 49(7), 4389-4397.

Khangarot, B.S. 1991. Toxicity of metals to a fresh-water tubificid worm, Tubifex tubifex (Müller). Bulletin of Environmental Contamination and Toxicology, 46(6), 906-912.

Khangarot, B.S. \& Rathore, R.S. 2004. Protective action of 24 amino acids on the toxicity of copper to a freshwater tubificid worm Tubifex tubifex Müller. Water Air and Soil Pollution, 157(1-4), 53-63.

Khangarot, B.S., Rathore, R.S. \& Singh, B.B. 2003. pH-Dependent toxicity of heavy metals to a freshwater sludgeworm Tubifex tubifex Müller. Bulletin of Environmental Contamination and Toxicology, 71(2), 283-289.

Kitamura, K. \& Shimizu, T. 2000a. Analyses of segment-specific expression of alkaline phosphatase activity in the mesoderm of the oligochaete annelid Tubifex: Implications for specification of segmental identity. Developmental Biology, 219(2), 214-223.

Kitamura, K. \& Shimizu, T. 2000b. Embryonic expression of alkaline phosphatase activity in the oligochaete annelid Tubifex. Invertebrate Reproduction \& Development, 37(1), 69-73.

Kitamura, K. \& Shimizu, T. 2002. Segment-specific expression of alkaline phosphatase in the Tubifex embryo requires DNA replication and mRNA synthesis. Journal of Experimental Zoology, 294(1), 68-76.

Komala, Z. 1992. Toxicity of fastac 10-EC, a pyrethroid insecticide, to Paramecium primaurelia and Tubifex sp. Folia Biologica-Krakow, 40(3-4), 109-112.

Kraaij, R.H., Tolls, J., Sijm, D., Cornelissen, G., Heikens, A. \& Belfroid, A. 2002. Effects of contact time on the sequestration and bioavailability of different classes of hydrophobic organic chemicals to benthic oligochaetes (Tubificidae). Environmental Toxicology and Chemistry, 21(4), 752-759.

Kracun-Kolarevic, M., Kolarevic, S., Atanackovic, A., Markovic, V., Gacic, Z., Paunovic, M. \& Vukovic-Gacic, B. 2015. Effects of 5-Fluorouracil, Etoposide and $\mathrm{CdCl} 2$ in aquatic oligochaeta Limnodrilus udekemianus claparede (Tubificidae) measured by comet assay. Water Air and Soil Pollution, 226(8). 
Kukkonen, J. \& Landrum, P.F. 1995. Effects of sediment-bound polydimethylsiloxane on the bioavailability and distribution of benzo a pyrene in lake sediment to Lumbriculus variegatus. Environmental Toxicology and Chemistry, 14(3), 523-531.

Kukkonen, J.V.K., Mitra, S., Landrum, P.F., Gossiaux, D.C., Gunnarsson, J. \& Weston, D. 2005. The contrasting roles of sedimentary plant-derived carbon and black carbon on sediment-spiked hydrophobic organic contaminant bioavailability to Diporeia species and Lumbriculus variegatus. Environmental Toxicology and Chemistry, 24(4), 877-885.

Kyselkova, I. \& Marsalek, B. 2000. Using of Daphnia pulex, Artemia salina and Tubifex tubifex for cyanobacterial microcystins toxicity detection. Biologia, 55(6), 637-643.

Lafont, M. 1987. Production of Tubificidae in the littoral-zone of Lake Leman near thonon-les-bains - a methodological approach. Hydrobiologia, $155,179-187$

Lafont, M. \& Juget, J. 1993. Rhyacodrilus-ardierae, sp. nov., a new species of Tubificidae (Oligochaeta) from the River Ardieres (France, tributary of the River Saone). Bulletin de la Societe Zoologique de France - Evolution et Zoologie, 118(2), 115-123.

Lagauzere, S., Boyer, P., Stora, G. \& Bonzom, J.M. 2009a. Effects of uraniumcontaminated sediments on the bioturbation activity of Chironomus riparius larvae (Insecta, Diptera) and Tubifex tubifex worms (Annelida, Tubificidae). Chemosphere, 76(3), 324-334.

Lagauzere, S., Terrail, R. \& Bonzom, J.M. 2009b. Ecotoxicity of uranium to Tubifex tubifex worms (Annelida, Clitellata, Tubificidae) exposed to contaminated sediment. Ecotoxicology and Environmental Safety, 72(2), 527-537.

Landrum, P.E., Leppanen, M., Robinson, S.D., Gossiaux, D.C., Burton, G.A., Greenberg, M., Kukkonen, J.V.K., Eadie, B.J. \& Lansing, M.B. 2004a. Comparing behavioral and chronic endpoints to evaluate the response of Lumbriculus variegatus to 3,4,3','-tetrachlorobiphenyl sediment exposures. Environmental Toxicology and Chemistry, 23(1), 187-194.

Landrum, P.F., Gedeon, M.L., Burton, G.A., Greenberg, M.S. \& Rowland, C.D. 2002. Biological responses of Lumbriculus variegatus exposed to fluoranthene-spiked sediment. Archives of Environmental Contamination and Toxicology, 42(3), 292-302.

Landrum, P.F., Leppanen, M., Robinson, S.D., Gossiaux, D.C., Burton, G.A., Greenberg, M., Kukkonen, J.V.K., Eadie, B.J. \& Lansing, M.B. 2004b. Effect of $3,4,3^{\prime}, 4^{\prime}$-tetrachlorobiphenyl on the reworking behavior of Lumbriculus variegatus exposed to contaminated sediment. Environmental Toxicology and Chemistry, 23(1), 178-186.

Lang, C. 1989. Effects of small-scale sedimentary patchiness on the distribution of tubificid and Lumbriculid worms in Lake Geneva. Freshwater Biology, 21(3), 477-481.

Lang, C. 2000. Response of oligochaete (Tubificidae and Lumbriculidae) and diptera Chironomidae communities to the decrease of phosphorus concentrations in Lake Geneva (Little Lake). Annales de Limnologie International Journal of Limnology, 36(1), 13-20.

Lanzavecchia, G., Deeguileor, M., Valvassori, R. \& Lanzavecchia, P. 1987. Analysis and reconstruction of unusual obliquely striated fibers in Lumbriculids (Annelida, Oligochaeta). Journal of Muscle Research and Cell Motility, 8(3), 209-219.

Lasier, P.J., Washington, J.W., Hassan, S.M. \& Jenkins, T.M. 2011. Perfluorinated chemicals in surface waters and sediments from northwest Georgia, USA, and their bioaccumulation in Lumbriculus variegatus. Environmental Toxicology and Chemistry, 30(10), 2194-2201.

Leonard, E.M. \& Wood, C.M. 2013. Acute toxicity, critical body residues, Michaelis-Menten analysis of bioaccumulation, and ionoregulatory disturbance in response to waterborne nickel in four invertebrates: Chironomus riparius, Lymnaea stagnalis, Lumbriculus variegatus and
Daphnia pulex. Comparative Biochemistry and Physiology - Part C: Toxicology and Pharmacology, 158(1), 10-21.

Leppanen, M.T. \& Kukkonen, J.V.K. 1998. Relationship between reproduction, sediment type, and feeding activity of Lumbriculus variegatus (Müller): Implications for sediment toxicity testing. Environmental Toxicology and Chemistry, 17(11), 2196-2202.

Leppanen, M.T. \& Kukkonen, J.V.K. 2000. Fate of sediment-associated pyrene and benzo a pyrene in the freshwater oligochaete Lumbriculus variegatus (Müller). Aquatic Toxicology, 49(3), 199-212.

Lestochova, E.I. 1994. Influence of small river conditions on the abundance of Tubificidae. Hydrobiologia, 278(1-3), 129-131.

Leynen, M., Van den Berckt, T., Aerts, J.M., Castelein, B., Berckmans, D. \& Ollevier, F. 1999. The use of Tubificidae in a biological early warning system. Environmental Pollution, 105(1), 151-154.

Liu, T.T., Diao, J.L., Di, S.S. \& Zhou, Z.Q. 2014. Stereoselective bioaccumulation and metabolite formation of triadimefon in Tubifex tubifex. Environmental Science \& Technology, 48(12), 6687-6693.

Liu, T.T., Diao, J.L., Di, S.S. \& Zhou, Z.Q. 2015. Bioaccumulation of isocarbophos enantiomers from laboratory-contaminated aquatic environment by Tubificid worms. Chemosphere, 124, 77-82.

Lobo, H. \& Espindola, E.L.G. 2014. Branchiura sowerbyi Beddard, 1892 (Oligochaeta: Naididae) as a test species in ecotoxicology bioassays: a review, in Pinder, A., Arslan, N. \& Wetzel, M. (Eds.). Proceedings of the $12^{\text {th }}$ International Symposium on Aquatic Oligochaeta, Zoosymposia, 59-69.

Lodh, N., Rizzo, D.M., Kerans, B.L., McGinnis, S., Fytilis, N. \& Stevens, L. 2015. If you've seen one worm, have you seen them all? Spatial, community, and genetic variability of tubificid communities in Montana. Freshwater Science, 34(3), 909-917.

Lohlein, B. 1996. Seasonal dynamics of aufwuchs Naididae (Oligochaeta) on Phragmites australis in a eutrophic lake. Hydrobiologia, 334(1-3), 115-123.

Lopez, L.C.S., Rodrigues, P. \& Rios, R.I. 1999. Frogs and snakes as phoretic dispersal agents of bromeliad ostracods (Limnocytheridae: Elpidium) and annelids (Naididae: Dero). Biotropica, 31(4), 705-708.

Lou, J.Q., Sun, P.D., Guo, M.X., Wu, G. \& Song, Y.Q. 2011. Simultaneous sludge reduction and nutrient removal (SSRNR) with interaction between Tubificidae and microorganisms: A full-scale study. Bioresource Technology, 102(24), 11132-11136.

Luszczek-Trojnar, E., Sroka, K., Klaczak, A., Nowak, M. \& Popek, W. 2014. Bioaccumulation and purification of cadmium in Tubifex tubifex. Turkish Journal of Fisheries and Aquatic Sciences, 14(4), 939-946.

Lyytikainen, M., Pehkonen, S., Akkanen, J., Leppanen, M. \& Kukkonen, J.V.K. 2007. Bioaccumulation and biotransformation of polycyclic aromatic hydrocarbons during sediment tests with oligochaetes (Lumbriculus variegatus). Environmental Toxicology and Chemistry, 26(12), 2660-2666.

Madill, J., Coates, K.A., Wetzel, M.J. \& Gelder, S.R. 1992. Common and scientific names of Aphanoneuran and clitellate annelids of the United States of America and Canada. Soil Biology \& Biochemistry, 24(12), 1259-1262.

Maenpaa, K., Leppanen, M.T. \& Kukkonen, J.V.K. 2009. Sublethal toxicity and biotransformation of pyrene in Lumbriculus variegatus (Oligochaeta). Science of the Total Environment, 407(8), 2666-2672.

Maestre, Z., Martinez-Madrid, M. \& Rodriguez, P. 2009. Monitoring the sensitivity of the oligochaete Tubifex tubifex in laboratory cultures using three toxicants. Ecotoxicology and Environmental Safety, 72(8), 2083-2089.

Marchese, M.R. \& Brinkhurst, R.0. 1996. A comparison of two tubificid oligochaete species as candidates for sublethal bioassay tests relevant to subtropical and tropical regions. Hydrobiologia, 334(1-3), 163-168.

Marian, M.P. \& Pandian, T.J. 1985. Interference of chironomus in an open culture system for Tubifex tubifex. Aquaculture, 44(3), 249-251. 
Marotta, R., Crottini, A., Prada, V. \& Ferraguti, M. 2009. A morphological reappraisal of Tubifex blanchardi Vejdovsky, 1891 (Clitellata: Tubificidae). Acta Zoologica, 90(2), 179-188.

Marotta, R., Crottini, A., Raimondi, E., Fondello, C. \& Ferraguti, M. 2014. A like but different: the evolution of the Tubifex tubifex species complex (Annelida, Clitellata) through polyploidization. BMC Evolutionary Biology, 14.

Martin, P., Ferraguti, M. \& Kaygorodova, I. 1998. Description of two new species of Rhynchelmis (Oligochaeta: Lumbriculidae) from Lake Baikal (Russia), using classical morphology and ultrastructure of spermatozoa. Annales de Limnologie - International Journal of Limnology, 34(3), 283-293.

Martin, P. \& Giani, N. 1995. 2 New species of epirodrilus (Oligochaeta, Tubificidae) from Lake Nyasa and Tanganyika (East-Africa), with redescriptions of E. slovenicus and E. michaelseni. Zoologica Scripta, 24(1), 13-19.

Martin, P.\& Kaygorodova, I. 2008. A new species of Pseudorhynchelmis Hrabe, 1982 (Clitellata: Lumbriculidae) from Lake Baikal, with re-descriptions of P. parva and P. olchonensis. Zootaxa, (1938), 23-39.

Martin, P., Martinez-Ansemil, E. \& Sambugar, B. 2010. The Baikalian genus Rhyacodriloides in Europe: phylogenetic assessment of Rhyacodriloidinae subfam. nov., within the Naididae (Annelida). Zoologica Scripta, 39(5), 462-482.

Martinez, V.G., Menger, G.J. \& Zoran, M.J. 2005. Regeneration and asexual reproduction share common molecular changes: upregulation of a neural glycoepitope during morphallaxis in Lumbriculus. Mechanisms of Development, 122(5), 721-732.

Martinez, V.G., Reddy, P.K. \& Zoran, M.J. 2006. Asexual reproduction and segmental regeneration, but not morphallaxis, are inhibited by boric acid in Lumbriculus variegatus (Annelida: Clitellata: Lumbriculidae). Hydrobiologia, 564(1), 73-86.

Martinez-Madrid, M., Rodriguez, P., Perez-Iglesias, J.I. \& Navarro, E. 1999. Sediment toxicity bioassays for assessment of contaminated sites in the Nervion River (Northern Spain). 2. Tubifex tubifex reproduction sediment bioassay. Ecotoxicology, 8(2), 111-124.

Martinsson, S., Achurra, A., Svensson, M. \& Erseus, C. 2013. Integrative taxonomy of the freshwater worm Rhyacodrilus falciformis s.l. (Clitellata: Naididae), with the description of a new species. Zoologica Scripta, 42(6), 612-622.

Matisoff, G., Wang, X.S. \& McCall, P.L. 1999. Biological redistribution of lake sediments by tubificid oligochaetes: Branchiura sowerbyi and Limnodrilus hoffmeisteri/Tubifex tubifex. Journal of Great Lakes Research, 25(1), 205-219.

Matsuo, K., Yoshida, H. \& Shimizu, T. 2005. Differential expression of caudal and dorsal genes in the teloblast lineages of the oligochaete annelid Tubifex tubifex. Development Genes and Evolution, 215(5), 238-247.

McKeyfender, D. \& Fender, W.M. 1988. Phagodrilus gen. nov. (Lumbriculidae) - systematics and biology of a predaceous oligochaete from western North America. Canadian Journal of Zoology - Revue Canadienne de Zoologie, 66(10), 2304-2311.

Meller, M., Egeler, P., Rombke, J., Schallnass, H., Nagel, R. \& Streit, B. 1998. Short-term toxicity of lindane, hexachlorobenzene, and copper sulfate to tubificid sludgeworms (Oligochaeta) in artificial media. Ecotoxicology and Environmental Safety, 39(1), 10-20.

Mermillod-Blondin, F., des Chatelliers, M.C. \& Gerino, M. 2003. Effects of the interaction between Tubificid worms on the functioning of hyporheic sediments: an experimental study in sediment columns. Archiv Fur Hydrobiologie, 156(2), 203-223.

Mermillod-Blondin, F., Foulquier, A., Gilbert, F., Navel, S., Montuelle, B., Bellvert, F., Comte, G., Grossi, V., Fourel, F., Lecuyer, C. \& Simon, L. 2013.
Benzo(a)pyrene inhibits the role of the bioturbator Tubifex tubifex in river sediment biogeochemistry. Science of the Total Environment, 450, 230-241.

Mermillod-Blondin, F., Nogaro, G., Datry, T., Malard, F. \& Gibert, J. 2005. Do Tubificid worms influence the fate of organic matter and pollutants in stormwater sediments? Environmental Pollution, 134(1), 57-69.

Mermillod-Blondin, F., Nogaro, G., Vallier, F. \& Gibert, J. 2008. Laboratory study highlights the key influences of stormwater sediment thickness and bioturbation by Tubificid worms on dynamics of nutrients and pollutants in stormwater retention systems. Chemosphere, 72(2), 213-223.

Milbrink, G. 1987. Biological characterization of sediments by standardized tubificid bioassays. Hydrobiologia, 155, 267-275.

Mino, L.A., Folco, S., de D’Angelo, A.M.P. \& Guerrero, N.R.V. 2006. Modeling lead bioavailability and bioaccumulation by Lumbriculus variegatus using artificial particles. Potential use in chemical remediation processes. Chemosphere, 63(2), 261-268.

Misra, R.B., Babu, G.S., Ray, R.S. \& Hans, R.K. 2002. Tubifex: A sensitive model for UV-B-induced phototoxicity. Ecotoxicology and Environmental Safety, 52(3), 288-295.

Molnar, L., Kiszler, G. \& Pollak, E. 2006a. Identification and pattern of primary sensory cells in the body wall epithelium of the tubificid worm, Limnodrilus hoffmeisteri. Hydrobiologia, 564(1), 45-50.

Molnar, L., Kiszler, G., Pollak, E. \& Deres, L. 2006b. Distribution pattern of gamma-amino butyric acid immunoreactive neural structures in the central and peripheral nervous system of the tubificid worm, Limnodrilus hoffmeisteri. Hydrobiologia, 564(1), 33-43.

Morev, A.P. 1992. On the taxonomical status of Alexandrovia ringulata and A. onegensis (Oligochaeta, Tubificidae). Zoologichesky Zhurnal, 71(5), 128-133.

Mosleh, Y.Y., Mofeed, J., Afifi, M. \& Almaghrabi, 0.A. 2014. Biological effects of pyrimethinal on aquatic worms (Tubifex tubifex) under laboratory conditions. Bulletin of Environmental Contamination and Toxicology, 92(1), 85-89.

Mosleh, Y.Y., Paris-Palacios, S., Ahmed, M.T., Mahmoud, F.M., Osman, M.A. \& Biagianti-Risbourg, S. 2007. Effects of chitosan on oxidative stress and metallothioneins in aquatic worm Tubifex tubifex (Oligochaeta, Tubificidae). Chemosphere, 67(1), 167-175.

Mosleh, Y.Y., Paris-Palacios, S., Couderchet, M., Biagianti-Risbourg, S. \& Vernet, G. 2005. Effects of the herbicide isoproturon on metallothioneins, growth, and antioxidative Defenses in the aquatic worm Tubifex tubifex (Oligochaeta, Tubificidae). Ecotoxicology, 14(5), 559-571.

Nakamoto, A., Arai, A. \& Shimizu, T. 2000. Cell lineage analysis of pattern formation in the Tubifex embryo. II. Segmentation in the ectoderm. International Journal of Developmental Biology, 44(7), 797-805.

Nakamoto, A., Arai, A. \& Shimizu, T. 2004. Specification of polarity of teloblastogenesis in the oligochaete annelid Tubifex: cellular basis for bilateral symmetry in the ectoderm. Developmental Biology, 272(1), 248-261.

Nakamoto, A., Arai, A. \& Shimizu, T. 2006. Generation of bilateral symmetry in the ectoderm of the Tubifex embryo: Involvement of cell-cell interactions. Hydrobiologia, 564(1), 19-32.

Narita, T. 2001. Cocoon deposition of Rhyacodrilus hiemalis Ohtaka (Tubificidae) in Lake Biwa, Japan. Hydrobiologia, 463, 141-148.

Narita, T. 2006. Seasonal vertical migration and aestivation of Rhyacodrilus hiemalis (Tubificidae, Clitellata) in the sediment of Lake Biwa, Japan. Hydrobiologia, 564(1), 87-93.

Naveed, M.I. 2012. Preliminary studies on aquatic Oligochaeta in and around Chennai, Tamil Nadu, India. Turkish Journal of Zoology, 36(1), 25-37.

Naveed, M.I., Thulasiraja, S., Karunakaran, S., Kulandaivel, C. \& Selvan, R.T. 2014. Preliminary survey of aquatic oligochaetes in Eastern Tamil Nadu, 
India, in Pinder, A., Arslan, N. \& Wetzel, M. (Eds.). Proceedings of the $12^{\text {th }}$ International Symposium on Aquatic Oligochaeta, Zoosymposia, 14-23.

Nemec, A.F.L. \& Brinkhurst, R.0. 1987. A comparison of methodological approaches to the subfamilial classification of the Naididae (Oligochaeta). Canadian Journal of Zoology, 65(3), 691-707.

Nybom, I., Waissi-Leinonen, G., Maenpaa, K., Leppanen, M.T., Kukkonen, J.V.K., Werner, D. \& Akkanen, J. 2015. Effects of activated carbon ageing in three PCB contaminated sediments: Sorption efficiency and secondary effects on Lumbriculus variegatus. Water Research, 85, 413-421.

Nybom, I., Werner, D., Leppanen, M.T., Siavalas, G., Christanis, K., Karapanagioti, H.K., Kukkonen, J.V.K. \& Akkanen, J. 2012. Responses of Lumbriculus variegatus to Activated Carbon Amendments in Uncontaminated Sediments. Environmental Science \& Technology, 46(23), 12895-12903.

O'Gara, B.A., Murray, P.M., Hoyt, E.M., Leigh-Logan, T. \& Smeaton, M.B. 2006. The Vitamin E analog Trolox reduces copper toxicity in the annelid Lumbriculus variegatus but is also toxic on its own. Neurotoxicology, 27(4), 604-614.

0'Rourke, S., Stone, V., Stolpe, B. \& Fernandes, T. 2015. Assessing the acute hazards of zinc oxide nanomaterials to Lumbriculus variegatus. Ecotoxicology, 24(6), 1372-1384.

Ohtaka, A. 1995. A new species of the genus Rhyacodrilus Bretscher (Oligochaeta, Tubificidae) from japanese lakes. Zoological Science, 12(4), 491-498.

Ohtaka, A. 2014. Profundal oligochaete faunas (Annelida, Clitellata) in japanese lakes, in Pinder, A., Arslan, N. \& Wetzel, M. (Eds.). Proceedings of the $12^{\text {th }}$ International Symposium on Aquatic Oligochaeta, Zoosymposia, 24-35.

Omodeo, P. \& Coates, K.A. 2001. New alluroidids (Annelida, Clitellata) from Guyana. Hydrobiologia, 463, 39-47.

Oplinger, R.W., Bartley, M. \& Wagner, E.J. 2011. Culture of Tubifex tubifex: Effect of feed type, ration, temperature, and density on juvenile recruitment, production, and adult survival. North American Journal of Aquaculture, 73(1), 68-75.

Otubu, J.E., Hunter, J.V., Francisco, K.L. \& Uchrin, C.G. 2006. Temperature effects on Tubificid worms and their relation to sediment oxygen demand. Journal of Environmental Science and Health - Part A: Toxic/ Hazardous Substances \& Environmental Engineering, 41(8), 1607-1613.

Ozdemir, A., Duran, M., Akyildiz, G.K.\& Sen, A.2011. EROD and metallothionein in Limnodrilus profundicola (Oligochaeta: Tubificidae) as an indicator of pollution exposure in the Curuksu stream of Menderes River, Denizli, Turkey. Desalination and Water Treatment, 26(1-3), 98-103.

Pakarinen, K., Petersen, E.J., Leppanen, M.T., Akkanen, J. \& Kukkonen, J.V.K. 2011. Adverse effects of fullerenes $(\mathrm{nC}(60))$ spiked to sediments on Lumbriculus variegatus (Oligochaeta). Environmental Pollution, 159(12), 3750-3756.

Paoletti, A. 1989. Cohort cultures of Tubifex tubifex forms. Hydrobiologia, 180, 143-150.

Paoletti, A.D. \& Sambugar, B. 1996. Aquatic Oligochaeta in Italy, with special reference to Naididae. Hydrobiologia, 334(1-3), 37-49.

Paris-Palacios, S., Mosleh, Y.Y., Almohamad, M., Delahaut, L., Conrad, A., Arnoult, F. \& Biagianti-Risbourg, S. 2010. Toxic effects and bioaccumulation of the herbicide isoproturon in Tubifex tubifex (Oligocheate, Tubificidae): A study of significance of autotomy and its utility as a biomarker. Aquatic Toxicology, 98(1), 8-14.

Pasteris, A., Bonacina, C. \& Bonomi, G. 1994. Observations on cohorts of Tubifex tubifex cultured at different food levels, using cellulose substrate. Hydrobiologia, 278(1-3), 315-320.

Pasteris, A., Bonomi, G. \& Bonacina, C. 1996. Age, stage and size structure as population state variables for Tubifex tubifex (Oligochaeta, Tubificidae). Hydrobiologia, 334(1-3), 125-132.
Peng, Y., Wang, H.Z. \& Cui, Y.D. 2014. Two species of Naididae (Annelida, Clitellata) from southern Tibet, China. ZooKeys, (444), 59-68.

Penttinen, 0.P. \& Kukkonen, J.V.K. 2000. Metabolic response of Lumbriculus variegatus to respiratory uncoupler in cold and anoxic water. Environmental Toxicology and Chemistry, 19(8), 2073-2075.

Petersen, S., Arlt, G., Faubel, A. \& Carman, K.R. 1998. On the nutritive significance of dissolved free amino acid uptake for the cosmopolitan oligochaete Nais elinguis Müller (Naididae). Estuarine, Coastal and Shelf Science, 46(1), 85-91.

Pinder, A. 2001. Notes on the diversity and distribution of Australian Naididae and Phreodrilidae (Oligochaeta: Annelida). Hydrobiologia, 463, 49-64.

Pinder, A.M., Eberhard, S.M. \& Humphreys, W.F. 2006. New phallodrilines (Annelida: Clitellata: Tubificidae) from Western Australian groundwater. Zootaxa, (1304), 31-48.

Postolache, C., Risnoveanu, G. \& Vadineanu, A. 2006. Nitrogen and phosphorous excretion rates by Tubificids from the Prahova River (Romania). Hydrobiologia, 553, 121-127.

Puigagut, J., Chazarenc, F. \& Comeau, Y. 2014. Influence of Tubificid worms on nutrient fluxes across water-sediment interface in fish farm settling ponds. Knowledge and Management of Aquatic Ecosystems, (413).

Purschke, G. 2003. Ultrastructure of phaosomous photoreceptors in Stylaria lacustris (Naididae, 'Oligochaeta', Clitellata) and their importance for the position of the Clitellata in the phylogenetic system of the Annelida. Journal of Zoological Systematics and Evolutionary Research, 41(2), 100-108.

Rathore, R.S. \& Khangarot, B.S. 2002. Effects of temperature on the sensitivity of sludge worm Tubifex tubifex Müller to selected heavy metals. Ecotoxicology and Environmental Safety, 53(1), 27-36.

Rathore, R.S. \& Khangarot, B.S. 2003. Effects of water hardness and metal concentration on a freshwater Tubifex tubifex Müller. Water Air and Soil Pollution, 142(1-4), 341-356.

Reynoldson, T.B., Rodriguez, P. \& Madrid, M.M. 1996. A comparison of reproduction, growth and acute toxicity in two populations of Tubifex tubifex (Müller, 1774) from the North American Great Lakes and Northern Spain. Hydrobiologia, 334(1-3), 199-206.

Robbins, J.A., Keilty, T., White, D.S. \& Edgington, D.N. 1989. Relationships among tubificid abundances, sediment composition, and accumulation rates in Lake Erie. Canadian Journal of Fisheries and Aquatic Sciences, 46(2), 223-231.

Rodriguez, P., Fend, S.V. \& Lenat, D.R. 2014. Sylphella puccoon gen. nov., sp. nov., and two additional new species of aquatic oligochaetes (Lumbriculidae, Clitellata) from poorly-known lotic habitats in North Carolina (USA). ZooKeys, (451), 1-32.

Rodriguez, P., Martinez-Madrid, M., Arrate, J.A. \& Navarro, E. 2001. Selective feeding by the aquatic oligochaete Tubifex tubifex (Tubificidae, (litellata). Hydrobiologia, 463, 133-140.

Rogge, R.W. \& Drewes, C.D. 1993. Assessing sublethal neurotoxicity effects in the fresh-water oligochaete, Lumbriculus variegatus. Aquatic Toxicology, 26(1-2), 73-89.

Romano Spica, V., Giampaoli, S., Buggiotti, L., Vitali, M., Gianfranceschi, G. \& Soldati, R. 2014. Environment health and intraspecific biodiversity in T. tubifex: a preliminary analysis of a population from Apennines springs. International Journal of Environmental Science \& Technology, 11(2), 461-468.

Ruidisch, S., Elmatbouli, M. \& Hoffmann, R.W. 1991. The role of Tubificid worms as an intermediate host in the life-cycle of Myxobolus pavlovskii (Akhmerov, 1954). Parasitology Research, 77(8), 663-667.

Sardo, A.M., Pereira, L., Gerhardt, A. \& Soares, A. 2011. Effect of the exposure to metal lead on the regenerative ability of Lumbriculus variegatus (Oligochaeta). Environmental Toxicology and Pharmacology, 31(1), 205-211. 
Sardo, A.M. \& Soares, A. 2010. Assessment of the effects of the pesticide imidacloprid on the behaviour of the aquatic oligochaete Lumbriculus variegatus. Archives of Environmental Contamination and Toxicology, 58(3), 648-656.

Sato, C. \& Ohtaka, A. 2012. Redescription of Piguetiella denticulata (Annelida, Clitellata, Naididae) from Japan and the Russian Far East, with a description of the genital organs in the species. Limnology, 13(1), 143-148.

Sauter, G. \& Gude, H. 1996. Influence of grain size on the distribution of tubificid oligochaete species. Hydrobiologia, 334(1-3), 97-101.

Schenkova, J. \& Cermak, V. 2013. Description of Pristina armata sp. nov. (Clitellata: Naididae: Pristininae) from a carnivorous plant (Nepenthes sp.) in Borneo, Indonesia. Zootaxa, 3686(5), 587-592.

Schubauerberigan, M.K., Dierkes, J.R., Monson, P.D. \& Ankley, G.T. 1993. PH-dependent toxicity of CD, CU, NI, PB and ZN to Ceriodaphnia dubia, Pimephales promelas, Hyalella azteca and Lumbriculus variegatus. Environmental Toxicology and Chemistry, 12(7), 1261-1266.

Schubauerberigan, M.K., Monson, P.D., West, C.W. \& Ankley, G.T. 1995. Influence of $\mathrm{pH}$ on the toxicity of ammonia to chironomus-tentans and Lumbriculus variegatus. Environmental Toxicology and Chemistry, 14(4), 713-717.

Schuler, L.J., Wheeler, M., Bailer, A.J. \& Lydy, M.J. 2003. Toxicokinetics of sediment-sorbed benzo a pyrene and hexachlorobiphenyl using the freshwater invertebrates Hyalella azteca, Chironomus tentans, and Lumbriculus variegatus. Environmental Toxicology and Chemistry, 22(2), 439-449.

Shimizu, T. 1986. Bipolar segregation of mitochondria, actin network, and surface in the Tubifex egg - role of cortical polarity. Developmental Biology, 116(1), 241-251.

Shimizu, T. 1988. Localization of actin networks during early development of Tubifex embryos. Developmental Biology, 125(2), 321-331.

Shimizu, T. 1989. Asymmetric segregation and polarized redistribution of pole plasm during early cleavages in the Tubifex embryo - role of actin networks and mitotic apparatus. Development Growth \& Differentiation, 31(3), 283-297.

Shimizu, T. 1990. Polar body formation in Tubifex eggs. Annals of the New York Academy of Sciences, 582, 260-272.

Shimizu, T. 1994. The prevention of smaller blastomeres of early Tubifex embryos from entering mitosis by unreplicated DNA. Developmental Biology, 161(1), 274-284.

Shimizu, T. 1995a. Lineage-specific alteration in cell-cycle structure in early Tubifex embryos. Development Growth \& Differentiation, 37(3), 263-272.

Shimizu, T. 1995b. Role of the cytoskeleton in the generation of spatial patterns in Tubifex eggs, in Capco, D.G. (Ed.). Cytoskeletal Mechanisms During Animal Development. Current Topics in Developmental Biology, 197-235.

Shimizu, T. 1996a. Behaviour of centrosomes in early Tubifex embryos: Asymmetric segregation and mitotic cycle-dependent duplication. Rouxs Archives of Developmental Biology, 205(5-6), 290-299.

Shimizu, T. 1996b. Ooplasmic redistribution in Tubifex eggs with selectively impaired cortical actin cytoskeleton. Developmental Biology, 180(1), 54-62.

Shimizu, T. 1996c. The first two cleavages in Tubifex involve distinct mechanisms to generate asymmetry in mitotic apparatus. Hydrobiologia, 334(1-3), 269-276.

Shimizu, T. 1997a. Reorganization of the cortical actin cytoskeleton during maturation division in the Tubifex egg: Possible involvement of protein kinase C. Developmental Biology, 188(1), 110-121.

Shimizu, T. 1997b. Separation of microvilli from Tubifex eggs upon activation: Its inhibition by concanavalin A hinders ooplasmic segregation and cleavage. Development Growth \& Differentiation, 39(6), 787-794.
Shimizu, T., Ishii, R. \& Takahashi, H. 1998. Unequal cleavage in the early Tubifex embryo. Development Growth \& Differentiation, 40(3), 257-266.

Shimizu, T., Kitamura, K., Arai, A. \& Nakamoto, A. 2001. Pattern formation in embryos of the oligochaete annelid Tubifex: cellular basis for segmentation and specification of segmental identity. Hydrobiologia, $463,123-131$

Sibley, T.H. \& Stohr, J.S. 1990. Accumulation of AM-241 and CM-244 from water and sediments by hyalella sp., and Tubifex sp. Bulletin of Environmental Contamination and Toxicology, 44(1), 165-172.

Singh, B.B., Chandra, R. \& Sharma, Y.K. 2008. Effect of pyridine and formaldehyde on a macrophyte (Lemna minor L.) and a sludge worm (Tubifex tubifex Müller) in fresh water microcosms. Applied Ecology and Environmental Research, 6(2), 21-35.

Singh, R.K., Chavan, S.L. \& Sapkale, P.H. 2007. Heavy metal concentrations in water, sediments and body tissues of red worm (Tubifex sp.) collected from natural habitats in Mumbai, India. Environmental Monitoring and Assessment, 129(1-3), 471-481.

Sjolin, E., Erseus, C. \& Kallersjo, M. 2005. Phylogeny of Tubificidae (Annelida, (litellata) based on mitochondrial and nuclear sequence data. Molecular Phylogenetics and Evolution, 35(2), 431-441.

Slootweg, T., Alvinerie, M., Egeler, P., Gilberg, D., Kukkonen, J.V.K., Oehlmann, J., Prasse, C., Sormunen, A.J. \& Liebig, M. 2010. Bioaccumulation of ivermectin from natural and artificial sediments in the benthic organism Lumbriculus variegatus. Journal of Soils and Sediments, 10(8), 1611-1622.

Smith, M.E. 1985a. Naididae (Oligochaeta) as hosts for mermithid nematodes (Enoplida, Mermithidae). Canadian Journal of Zoology - Revue Canadienne de Zoologie, 63(6), 1459-1462.

Smith, M.E. 1985b. Setal morphology and its intraspecific variation in Derodigitata and Dero-nivea (Oligochaeta, Naididae). Transactions of the American Microscopical Society, 104(1), 45-51.

Smith, M.E. 1985c. Tubificid worms - important organisms in aquatic ecosystems. American Biology Teacher, 47(7), 412-415.

Smutna, M., Hilscherova, K., Paskova, V. \& Marsalek, B. 2008. Biochemical parameters in Tubifex tubifex as an integral part of complex sediment toxicity assessment. Journal of Soils and Sediments, 8(3), 154-164.

Snimschikova, L.N. 1989. New species and subspecies of the genus Baikalodrilus (Oligochaeta, Tubificidae). Zoologichesky Zhurnal, 68(9), 23-34.

Snimschikova, L.N. 1991. A revision of Lycodrilus phreodriloides (Oligochaeta, Tubificidae). Zoologica Scripta, 20(3), 221-223.

Snimschikova, L.N. \& Akinschina, T.V. 1993. New species of the genus Tasserkidrilus (Oligochaeta, Tubificidae) from Lake Baikal. Zoologichesky Zhurnal, 72(10), 5-13.

Snimschikova, L.N. \& Akinschina, T.V. 1994a. Isochaetides-resorptus sp. nov. (Oligochaeta, Tubificidae). Zoologichesky Zhurnal, 73(9), 158-161.

Snimschikova, L.N. \& Akinschina, T.W. 1994b. Rhyacodrilus-stephensoni (Oligochaeta, Tubificidae) from Lake Baikal. Zoologichesky Zhurnal, 73(6), 22-27.

Snimshchikova, L.N. 1989. Baikalodrilus multicrystallifer sp. nov. (Oligochaeta, Tubificidae). Zoologichesky Zhurnal, 68(2), 300-303.

Snimshchikova, L.N. 1998. Revision of the genus Lycodrilus and description of the evolution of Limnodrilus (Oligochaeta, Tubificidae) species in Lake Baikal. I. Revision of Lycodrilus dybowskii Grube species and Tubipenifer Semernoy genus. Zoologichesky Zhurnal, 77(5), 540-547.

Snimstschikova, L.N. 1985. The taxonomy of the genus svetlovia (Oligochaeta, Tubificidae) from the Baikal Lake. Zoologichesky Zhurnal, 64(8), 1148-1153

Song, Z.H. 2007. Effects of Pentachlorophenol on Galba pervia, Tubifex sinicus and Chironomus plumousus Larvae. Bulletin of Environmental Contamination and Toxicology, 79(3), 278-282. 
Soni, A.K. \& Joshi, P.C. 1997. High sensitivity of Tubifex for ultraviolet-B. Biochemical and Biophysical Research Communications, 231(3), 818-819.

Soors, J., van Haaren, T., Timm, T. \& Speybroeck, J. 2013. Bratislavia dadayi (Michaelsen, 1905) (Annelida: Clitellata: Naididae): a new nonindigenous species for Europe, and other non-native annelids in the Schelde estuary. Aquatic Invasions, 8(1), 37-44.

Spencer, D.R. \& Wisseman, R.E. 1993. Some new records of Naididae and Tubificidae (Annelida, Oligochaeta) from Washington. Great Basin Naturalist, 53(4), 395-401.

Sporka, F. 1996. First record of Aulodrilus pigueti (Oligochaeta, Tubificidae) from the River Morava in Slovakia. Biologia, 51(5), 494-494.

Stacey, D.F. \& Coates, K.A. 1996. Oligochaetes (Naididae, Tubificidae, Opistocystidae, Enchytraeidae, Sparganophilidae and Alluroididae) of Guyana. Hydrobiologia, 334(1-3), 17-29.

Stacey, D.F. \& Hubley, B.R. 1994. New records of a sludge worm Teneridrilusflexus erseus and hiltunen (Oligochaeta, Tubificidae) from Lake Huron. Canadian Field-Naturalist, 108(2), 182-185.

Steen Redeker, E., van Campenhout, K., Bervoets, L., Reijnders, H. \& Blust, R. 2007. Subcellular distribution of $C d$ in the aquatic oligochaete Tubifex tubifex, implications for trophic availability and toxicity. Environmental Pollution, 148(1), 166-175.

Takahashi, H. \& Shimizu, T. 1997. Role of intercellular contacts in generating an asymmetric mitotic apparatus in the Tubifex embryo. Development Growth \& Differentiation, 39(3), 351-362.

Theuer, M., Pilz, I., Schwarz, E., Wilhelm, P., Mainwaring, M.G. \& Vinogradov, S.N. 1985. Molecular-size and shape of the native and reassociated forms of the extracellular hemoglobin of Tubifex tubifex. International Journal of Biological Macromolecules, 7(1), 25-29.

Tian, Y. \& Lu, Y.B. 2010. Simultaneous nitrification and denitrification process in a new Tubificidae reactor for minimizing nutrient release during sludge reduction. Water Research, 44(20), 6031-6040.

Tian, Y., Lu, Y.B., Chen, L. \& Lin, H.L. 2010. Optimization of process conditions with attention to the sludge reduction and stable immobilization in a novel Tubificidae reactor. Bioresource Technology, 101(15), 6069-6076.

Tichy, M., Rucki, M., Hanzlikova, I. \& Roth, Z. 2007. The Tubifex tubifex assay for the determination of acute toxicity. Atla-Alternatives to Laboratory Animals, 35(2), 229-237.

Timm, T. 1998. Lumbriculidae (Oligochaeta) of Lake Taimyr. Journal of Natural History, 32(9), 1291-1301.

Tolgyessy, P. 1988. The degradation of bentazone and chlorotoluron in aqueous-solutions by gamma-radiation - biodegradability and toxicity to Tubifex tubifex of radiolysis products. Journal of Radioanalytical and Nuclear Chemistry-Letters, 128(4), 321-329.

Tweeten, K.A. \& Abitz, A. 2012. Patterns of cleavage and gastrulation in embryos of freshwater oligochaetes from the Lumbriculus complex. Integrative and Comparative Biology, 52, E341-E341.

Tweeten, K.A. \& Reiner, A. 2012. Characterization of serine proteases of Lumbriculus variegatus and their role in regeneration. Invertebrate Biology, 131(4), 322-332.

Urbisz, A.Z., Chajec, L. \& Swiatek, P. 2015. The ovary of Tubifex tubifex (Clitellata, Naididae, Tubificinae) is composed of one, huge germ-line cyst that is enriched with cytoskeletal components. Plos One, 10(5).

Varela, M.E. 1990. Taxonomic and ecological notes about some oligochaetes of fresh-water of northeastern Argentina. 1. Naididae. Studies on Neotropical Fauna and Environment, 25(4), 223-233.

Verma, S., Das, S. \& Khangarot, B.S. 2011. Toxicity of metallic oxides nanoparticle suspensions to a freshwater sludge worm Tubifex tubifex Müller. Journal of Biomedical Nanotechnology, 7(1), 216-217.

Vivien, R., Wyler, S., Lafont, M. \& Pawlowski, J. 2015. Molecular barcoding of aquatic oligochaetes: Implications for biomonitoring. Plos One, 10(4).
Volpers, M. \& Neumann, D. 2005. Tolerance of two tubificid species (Tubifex tubifex and Limnodrilus hoffmeisteri) to hypoxic and sulfidic conditions in novel, long-term experiments. Archiv Fur Hydrobiologie, 164(1), 13-38.

Wang, J.F., Maul, J.D., Mayer, G.D. \& Cobb, G.P. 2012. Uptake of fullerene (C60) induced catalase (CAT) activity in Lumbriculus variegatus. Abstracts of Papers of the American Chemical Society, 244.

Wang, J.F., Wages, M., Yu, S.Y., Maul, J.D., Mayer, G., Hope-Weeks, L. \& Cobb, G.P. 2014. Bioaccumulation of fullerene $(C-60)$ and corresponding catalase elevation in Lumbriculus variegatus. Environmental Toxicology and Chemistry, 33(5), 1135-1141.

West, C.W., Ankley, G.T., Nichols, J.W., Elonen, G.E. \& Nessa, D.E. 1997. Toxicity and bioaccumulation of 2,3,7,8-tetrachlorodibenzo-p-dioxin in long-term tests with the freshwater benthic invertebrates Chironomus tentans and Lumbriculus variegatus. Environmental Toxicology and Chemistry, 16(6), 1287-1294.

Wetzel, M.J. 1987. Limnodrilus tortilipenis, a new north american species of fresh-water Tubificidae (Annelida: Clitellata: Oligochaeta). Proceedings of the Biological Society of Washington, 100(1), 182-185.

Wiederholm, T. \& Dave, G. 1989. Toxicity of metal polluted sediments to Daphnia magna and Tubifex tubifex. Hydrobiologia, 176, 411-417.

Wiederholm, T., Wiederholm, A.M. \& Milbrink, G. 1987. Bulk sediment bioassays with 5 species of fresh-water oligochaetes. Water Air and Soil Pollution, 36(1-2), 131-154.

Wiegand, C., Pehkonen, S., Akkanen, J., Penttinen, O.P. \& Kukkonen, J.V.K. 2007. Bioaccumulation of paraquat by Lumbriculus variegatus in the presence of dissolved natural organic matter and impact on energy costs, biotransformation and antioxidative enzymes. Chemosphere, 66(3), 558-566.

Wiramanaden, C.I.E., Orr, P.L. \& Russel, C.K. 2015. Assessment of radium-226 bioavailability and bioaccumulation downstream of decommissioned uranium operations, using the caged oligochaete (Lumbriculus variegatus). Environmental Toxicology and Chemistry, 34(3), 507-517.

Yanez, E., Cuadrado, S. \& Martinez-Ansemil, E. 2006. External sense organs in freshwater oligochaetes (Annelida, Clitellata) revealed by scanning electron microscopy. Journal of Morphology, 267(2), 198-207.

Yoshioka, Y., Ose, Y. \& Sato, T. 1986. Testing and evaluation of chemical toxicity on Tubifex. Eisei Kagaku - Japanese Journal of Toxicology and Environmental Health, 32(4), 308-311.

You, J., Brennan, A. \& Lydy, M.J. 2009. Bioavailability and biotransformation of sediment-associated pyrethroid insecticides in Lumbriculus variegatus. Chemosphere, 75(11), 1477-1482.

Zattara, E.E. \& Bely, A.E. 2015. Fine taxonomic sampling of nervous systems within Naididae (Annelida: Clitellata) reveals evolutionary lability and revised homologies of annelid neural components. Frontiers in Zoology, 12.

Zhang, L., Liao, Q.J.H., Gu, X.Z., He, W., Zhang, Z. \& Fan, C.X. 2014a. Oxygen and phosphorus dynamics in freshwater sediment after the deposition of flocculated cyanobacteria and the role of Tubificid worms. Journal of Hazardous Materials, 266, 1-9.

Zhang, L., Shang, J.G., He, W., You, B.S. \& Fan, C.X. 2014b. The role of Tubificid worms (Limnodrilus hoffmeisteri) in sediment resuspension: a microcosm study. Annales de Limnologie - International Journal of Limnology, 50(3), 253-260.

Zhang, X.F., Liu, Z.W., Jeppesen, E. \& Taylor, W.D. 2014c. Effects of depositfeeding Tubificid worms and filter-feeding bivalves on benthic-pelagic coupling: Implications for the restoration of eutrophic shallow lakes. Water Research, 50, 135-146.

Zoran, M.J. \& Drewes, C.D. 1988. The rapid tail withdrawal reflex of the tubificid worm, Branchiura sowerbyi. Journal of Experimental Biology, $137,487-500$. 
Zoran, M.J., Drewes, C.D., Fourtner, C.R. \& Siegel, A.J. 1988. The lateral giant fibers of the tubificid worm, Branchiura sowerbyi - structural and functional asymmetry in a paired interneuronal system. Journal of Comparative Neurology, 275(1), 76-86.

\section{SCOPUS}

Achurra, A., Des Chatelliers, M.C. \& Rodriguez, P. 2012. Troglodrilus jugeti sp. nov. (Annelida, Clitellata, Tubificinae), a new stygobiont oligochaete species from south-western europe. Zootaxa, (3229), 35-46. Retrieved from: www.scopus.com

Achurra, A., Elejalde, M.A. \& Rodriguez, P. 2011. Phylogenetic analysis of oligochaete Tubificinae (Annelida: Clitellata) based on mitochondrial sequence data. Invertebrate Systematics, 25(3), 208-218. doi: 10.1071/ $\underline{\mathrm{IS} 10040}$

Achurra, A. \& Rodriguez, P. 2008. Biodiversity of groundwater oligochaetes from a karst unit in northern Iberian Peninsula: Ranking subterranean sites for conservation management. Hydrobiologia, 605(1), 159-171. doi: 10.1007/s10750-008-9331-2

Achurra, A., Rodriguez, P. \& Reynoldson, T.B. 2015. Is the cantabrian region of northern Spain a biodiversity hotspot for obligate groundwater fauna? The case of oligochaetes (Annelida, Clitellata). Hydrobiologia, 745(1), 151-166. doi: 10.1007/s10750-014-2101-4

Alejandra Pujals, M. 1985. Especies de los géneros Pristina Ehrenberg, 1828 y Bratislavia Kosel, 1976 (Oligochaeta: Naididae) en la provincia de Buenos Aires, Argentina. Studies on Neotropical Fauna and Environment, 20(4), 203-210. doi: 10.1080/01650528509360690

Alexander, A.C., Culp, J.M., Liber, K. \& Cessna, A.J. 2007. Effects of insecticide exposure on feeding inhibition in mayflies and oligochaetes. Environmental Toxicology and Chemistry, 26(8), 1726-1732. doi: 10.1897/07-015R.1

Alves, R.D.G., Marchese, M.R. \& Escarpinati, S.C. 2006. Oligochaeta (Annelida, Clitellata) in lotic environments in the state of São Paulo, Brazil. Iheringia - Série Zoologia, 96(4), 431-435. doi: 10.1590/5007347212006000400007

Alves, R.D.G., Marchese, M.R. \& Martins, R.T. 2008. Oligochaeta (Annelida, Clitellata) of lotic environments at Parque Estadual Intervales (São Paulo, Brazil). Biota Neotropica, 8(1), 69-72. doi: 10.1590/S1676$\underline{06032008000100009}$

Anderson, R.V. \& Holm, D.J. 1987. Chaetogaster limnaei (Oligochaeta: Naididae) infesting unionid mollusks (Pelecypoda: Unionidae) and corbicula fluminea (Pelecypoda: Corbiculidae) in pool 19, Mississippi River. Journal of Freshwater Ecology, 4(1), 61-64. doi: 10.1080/02705060.1987.9665161

Andrews, J.M., Childress, J.N., lakovidis, T.J. \& Langford, G.J. 2015. Elucidating the life history and ecological aspects of Allodero hylae (Annelida: (litellata: Naididae), a parasitic oligochaete of invasive cuban tree frogs in Florida. Journal of Parasitology, 101(3), 275-281. doi: 10.1645/14608.1

Ankley, G.T., Leonard, E.N. \& Mattson, V.R. 1994. Prediction of bioaccumulation of metals from contaminated sediments by the oligochaete, Lumbriculus variegatus. Water Research, 28(5), 1071-1076. doi: 10.1016/00431354(94)90192-9

Anlauf, A. 1997. Enzyme variability of Tubifex tubifex (Müller) (Oligochaeta, Tubificidae) and seven other tubificid species. Archiv Fur Hydrobiologie, 139(1), 83-100. Retrieved from: www.scopus.com

Anlauf, A. 1994. Some characteristics of genetic variants of Tubifex tubifex (Müller, 1774) (Oligochaeta: Tubificidae) in laboratory cultures. Hydrobiologia, 278(1-3), 1-6. doi: 10.1007/BF00142306
Antonio, D.B., Andree, K.B., McDowell, T.S. \& Hedrick, R.P. 1998. Detection of Myxobolus cerebralis in rainbow trout and oligochaete tissues by using a nonradioactive in situ hybridization (ISH) protocol. Journal of Aquatic Animal Health, 10(4), 338-347. doi: 10.1577/1548-8667(1998)010<0338:DOMCIR >2.0.C0;2

Arimoro, F.O., lkomi, R.B. \& Iwegbue, C.M.A. 2007. Ecology and abundance of oligochaetes as indicators of organic pollution in an urban stream in southern Nigeria. Pakistan Journal of Biological Sciences, 10(3), 446-453. Retrieved from: www.scopus.com

Arkhipova, N.R. 1996. Morphology of pectinate setae in Tubificids (Tubificidae, Oligochaeta). Zoologicheskii Zhurnal, 75(2), 186-187. Retrieved from: www.scopus.com

Armendáriz, L., Ocón, C. \& Rodrigues Capítulo, A. 2012. Potential responses of oligochaetes (Annelida, Clitellata) to global changes: Experimental fertilization in a lowland stream of Argentina (South America). Limnologica, 42(2), 118-126. doi: 10.1016/j.limno.2011.09.005

Armendariz, L.C. 1999. Population dynamics of Allonais lairdi (Oligochaeta, Naididae) from Los Talas, Buenos Aires Province. [Dinamica poblacional de Allonais lairdi (Oligochaeta, Naididae) en Los Talas, Provincia de Buenos Aires]. Ecologia Austral, 9(1-2), 20-27. Retrieved from: www.scopus.com

Armendáriz, L.C. 2008. Life cycle of Dero (Aulophorus) costatus Marcus, 1944 (Tubificidae, Oligochaeta) in a vegetated pond at Los Talas, Argentina. [Ciclo de vida de Dero (Aulophorus) costatus Marcus, 1944 (Tubificidae, Oligochaeta) en un cuerpo de agua con vegetacion flotante en Los Talas, Argentina]. Gayana, 72(1), 23-30. Retrieved from: www.scopus.com

Armendáriz, L.C. 2000. Population dynamics of Stylaria lacustris (Linnaeus, 1767) (Oligochaeta, Naididae) in Los Talas, Argentina. Hydrobiologia, 438, 217-226. doi: 10.1023/A:1004139622036

Armendáriz, L.C. \& César, I.I. 2001. The distribution and ecology of littoral Oligochaeta and Aphanoneura (Annelida) of the natural and historical reserve of Isla Martín García, Río de la Plata River, Argentina. Hydrobiologia, 463, 207-216. doi: 10.1023/A:1013120128722

Arslan, N. 2006. Records of Aphanoneura and aquatic oligochaetes from Turkey. Fresenius Environmental Bulletin, 15(4), 249-254. Retrieved from: www.scopus.com

Arslan, N., Koç, B. \& Çiçek, A. 2010. Metal contents in water, sediment, and Oligochaeta Chironomidae of Lake Uluabat, a ramsar site of Turkey. The Scientific World Journal, 10, 1269-1281. doi: 10.1100/tsw.2010.117

Arslan, N. \& Sahin, Y. 2006. A preliminary study on the identification of the littoral oligochaete (Annelida) and Chironomidae (Diptera) fauna of Lake Kovada, a national park in Turkey. Turkish Journal of Zoology, 30(1), 67-72. Retrieved from: www.scopus.com

Arslan, N. \& Şahin, Y. 2004. First records of some Naididae (Oligochaeta) species for Turkey. [Türiye Için bazi Naididae (Oligochaeta) Türlerinin ilk Kayitlari]. Turkish Journal of Zoology, 28(1), 7-18. Retrieved from: www. scopus.com

Arslan, N. \& Şahin, Y. 2003. Two new records of Aulodrilus Bretscher, 1899 (Oligochaeta, Tubificidae) for the turkish fauna. [Türkiye Faunasi lçin Iki Yeni Aulodrilus Bretscher, 1899 (Oligochaeta, Tubificidae) Türü]. Turkish Journal of Zoology, 27(4), 275-280. Retrieved from: www.scopus.com

Arslan, N., Timm, T. \& Erséus, C. 2007. Aquatic Oligochaeta (Annelida) of Ballkdaml wetland (Turkey), with description of two new species of Phallodrilinae. Biologia, 62(3), 323-334. doi: 10.2478/s11756-007$\underline{0055-y}$

Atanacković, A., Šporka, F., Tomović, J., Vasiljević, B., Marković, V., Simić, V. \& Paunović, M. 2012. First record of Bothrioneurum vejdovskyanum Štolc, 1886 (Oligochaeta, Tubificidae) in Serbia. Archives of Biological Sciences, 64(3), 1123-1126. doi: 10.2298/ABS1203123A

Atanacković, A.D., Šporka, F., Csányi, B., Vasiljević, B.M., Tomović, J.M. \& Paunović, M.M. 2013. Oligochaeta of the Danube River - a faunistical 
review. Biologia (Poland), 68(2), 269-277. doi: 10.2478/s11756-0130155-9

Back, H. \& Prosi, F. 1985. Distribution of inorganic cations in Limnodrilus udekemianus (Oligochaeta, Tubificidae) using laser induced microprobe mass analysis, with special emphasis on heavy metals. Micron and Microscopica Acta, 16(3), 145-150. doi: 10.1016/0739-6260(85)90058-9

Balatre-Veltz, I., Biagianti-Risbourg, S. \& Vernet, G. 1999. On the cephalic regeneration of Lumbriculus variegatus Müller 1774 (Annelida, Oligochaeta). [Sur la régénération céphalique de Lumbriculus variegatus Müller, 1774 (Annelida, Oligocheta)]. Bulletin de la Societe Zoologique de France, 124(1), 101-109. Retrieved from: www.scopus.com

Baldo, L. \& Ferraguti, M. 2005. Mixed reproductive strategy in Tubifex tubifex (Oligochaeta, Tubificidae)? Journal of Experimental Zoology - Part A: Comparative Experimental Biology, 303(2), 168-177. doi: 10.1002/ jez.a.144

Balik, S., Ustaoğlu, M.R. \& Yildiz, S. 2004. Oligochaeta and Aphanoneura (Annelida) fauna of the gediz delta (Menemen-Izmir). Turkish Journal of Zoology, 28(3), 183-197. Retrieved from: www.scopus.com

Baturina, M. 2012. Distribution and diversity of aquatic Oligochaeta in small streams of the middle taiga. Turkish Journal of Zoology, 36(1), 75-84. doi: 10.3906/z00-1002-64

Bauer-Hilty, A., Dallinger, R. \& Berger, B. 1989. Isolation and partial characterization of a cadmium-binding protein from Lumbriculus variegatus (Oligochaeta, Annelida). Comparative Biochemistry and Physiology - Part C: Toxicology and Pharmacology, 94(2), 373-379. doi: 10.1016/0742-8413(89)90085-6

Bazzanti, M. \& Lafont, M. 1985. Variability in the spermathecal setae of Potamothrix heuscheri (Bretscher) (Oligochaeta, Tubificidae) in Lake Nemi and notes on the relationship between this species and the trophic level of lakes. [Variabilité des soies spermathécales de Potamothrix heuscheri (Bretscher) (Oligochaeta, Tubificidae) dans le lac de Nemi et remarques sur la relation entre cette espèce et le degré de trophie des lacs]. Annales de Limnologie, 21(2), 107-115. doi: 10.1051/ $\underline{\text { limn } / 1985010}$

Beauchamp, K.A., Kathman, R.D., McDowell, T.S. \& Hedrick, R.P. 2001. Molecular phylogeny of tubificid oligochaetes with special emphasis on Tubifex tubifex (Tubificidae). Molecular Phylogenetics and Evolution, 19(2), 216-224. doi: $10.1006 / \mathrm{mpev} .2001 .0923$

Behrend, R.D.L., Fernandes, S.E.P., Fujita, D.S. \& Takeda, A.M. 2009. Eight years of monitoring aquatic Oligochaeta from the Baía and Ivinhema Rivers. [0ito anos de monitoramento de Oligochaeta aquáticas nos Rios Baía e Ivinhema]. Brazilian Journal of Biology, 69 (suppl. 2), 559-571. Retrieved from: www.scopus.com

Behrend, R.D.L., Takeda, A.M., Gomes, L.C. \& Fernandes, S.E.P. 2012. Using Oligochaeta assemblages as an indicator of environmental changes. [Usando assembléias de Oligochaeta como um indicador de mudanças ambientais]. Brazilian Journal of Biology, 72(4), 873-884. doi: 10.1590/ $\underline{\text { S1519-69842012000500014 }}$

Behrend, R.D.L., Teixeira, M.C., Fernandes, S.E.P., Camargo, J.C., Rosin, G.C. \& Takeda, A.M. 2013. Effects of a native and a non-native macrophyte species of hydrocharitaceae on CHIRONOMIDAE and Oligochaeta assemblages structure. [Efeitos de uma espécie de macrófita nativa e uma invasora de Hydrocharitaceae sobre a estrutura das assembleias de Chironomidae e Oligochaeta]. Acta Scientiarum - Biological Sciences, 35(3), 351-358. doi: 10.4025 /actascibiolsci.v35i3.10855

Bely, A.E. 1999. Decoupling of fission and regenerative capabilities in an asexual oligochaete. Hydrobiologia, 406, 243-251. doi: 10.1023/A:1003763915697

Bergter, A., Hunnekuhl, V.S., Schniederjans, M. \& Paululat, A. 2007. Evolutionary aspects of pattern formation during clitellate muscle development. Evolution and Development, 9(6), 602-617. doi: 10.1111/j.1525-142X.2007.00184.x

Bernoud, S., Lafont, M. \& Durbec, A. 2003. Ecological diagnostic methods based on benthic Oligochaeta communities; technical and economic viewpoints. [Diagnostic écologique des sédiments à partir des peuplements d'oligochètes; aspects techniques et économiques]. Techniques - Sciences - Methodes, (5), 69-76. Retrieved from: www. scopus.com

Bingham, C.R. \& Miller, A.C. 1989. Colonization of a man-made gravel bar by Oligochaeta. Hydrobiologia, 180(1), 229-234. doi: 10.1007/BF00027555

Blettler, M., Amsler, M., De Drago, I.E. \& Marchese, M. 2008. Effects of stream hydraulics and other environmental variables on density of Narapa bonettoi (Oligochaeta) in the Paraná River system. River Research and Applications, 24(8), 1124-1140. doi: 10.1002/rra.1115

Bock, S., Sedlmeier, U.A. \& Hoffmann, K.H. 1989. Metabolism of absorbed short-chain carboxylic acids by the freshwater oligochaete Tubifex tubifex. Comparative Biochemistry and Physiology - Part B: Biochemistry and Molecular Biology, 92(1), 35-40. doi: 10.1016/0305-0491(89)90309$\underline{X}$

Boi, S. \& Ferraguti, M. 2001. Temporal pattern of the double sperm line production in Tubifex tubifex (Annelida, Oligochaeta). Hydrobiologia, 463, 103-106. doi: 10.1023/A:1013191205524

Bojková, J., Schenková, J., Horsák, M. \& Hájek, M. 2011. Species richness and composition patterns of clitellate (Annelida) assemblages in the treeless spring fens: The effect of water chemistry and substrate. Hydrobiologia, 667(1), 159-171. doi: 10.1007/s10750-011-0634-3

Bonacina, C., Pasteris, A., Bonomi, G. \& Marzuoli, D. 1994. Quantitative observations on the population ecology of Branchiura sowerbyi (Oligochaeta, Tubificidae). Hydrobiologia, 278(1-3), 267-274. doi: 10.1007/BF00142334

Bonacinal, C., Bonomi, G. \& Monti, C. 1987. Progress in cohort cultures of aquatic Oligochaeta. Hydrobiologia, 155(1), 163-169. doi: $10.1007 /$ BF00025645

Bonomi, G. \& Pasteris, A. 2006. From demographic strategies to mathematical models: Trends in population dynamics studies of aquatic Oligochaeta. Hydrobiologia, 564 (1 spec. iss.), 61-71. doi: 10.1007/s10750-005-1708-x

Bouguenec, V. \& Giani, N. 1989. Aquatic Oligochaeta as prey for invertebrates and vertebrates: A review. [Les Oligochetes aquatiques en tant que proies des Invertebres et des Vertebres: une revue]. Acta Oecologica - Oecologia Applicata, 10(3), 177-196. Retrieved from: www.scopus.com

Boumaiza, M., Giani, N. \& Martinez-Ansemil, E. 1986. Oligochaeta and Aphanoneura in the running waters of Tunisia. II. A key for determining the species presently tallied. [Les Oligochètes et Aphanoneura des eaux courantes de Tunisie. II. Clé pour la détermination des espèces actuellement recensées]. Archives de I'Institut Pasteur de Tunis, 63(2-3), 299-323. Retrieved from: www.scopus.com

Boumaiza, M., Martinez-Ansemil, E. \& Giani, N. 1986. Oligochaetes and Aphanoneura in streams of Tunisia. I. Faunistic data. [Les Oligochètes et Aphanoneura des eaux courantes deTunisie. I - Données faunistiques]. Annales de Limnologie, 22(3), 231-237. doi: 10.1051/limn/1986021

Bowker, D.W., Wareham, M.T. \& Learner, M.A. 1985. A choice chamber experiment on the selection of algae as food and substrata by Nais elinguis (Oligochaeta: Naididae). Freshwater Biology, 15(5), 547-557. doi: 10.1111/j.1365-2427.1985.tb00225.x

Bowker, D.W., Wareham, M.T. \& Learner, M.A. 1985. The ingestion and assimilation of algae by Nais elinguis (Oligochaeta: Naididae). Oecologia, 67(2), 282-285. doi: 10.1007/BF00384300

Brinkhurst, R.O. \& Nemac, A.F.L. 1987. A comparison of phenetic and phylogenetic methods applied to the systematics of Oligochaeta. Hydrobiologia, 155(1), 65-74. doi: 10.1007/BF00025632 
Brinkhurst, R.0., Qi Sang \& Liang Yanling. 1990. The aquatic Oligochaeta from the people's Republic of China. Canadian Journal of Zoology, 68(5), 901-916. doi: 10.1139/z90-131

Brown, L., Finston, T., Humphreys, G., Eberhard, S. \& Pinder, A. 2015. Groundwater oligochaetes show complex genetic patterns of distribution in the pilbara region of western Australia. Invertebrate Systematics, 29(5), 405-420. doi: $10.1071 /$ IS14037

Brunson, E.L., Canfield, T.J., Dwyer, F.J., Ingersoll, C.G. \& Kemble, N.E. 1998. Assessing the bioaccumulation of contaminants from sediments of the upper Mississippi River using field-collected oligochaetes and laboratory exposed Lumbriculus variegatus. Archives of Environmental Contamination and Toxicology, 35(2), 191-201. doi: 10.1007/s002449900367

Bunke, D. 1998. Ultrastructure of the nephrostome in Enchytraeus albidus (Annelida, Clitellata). Zoomorphology, 118(3), 177-182. doi: 10.1007/ s004350050067

Bunke, D. 2000. Ultrastructure of the preseptal part of metanephridia in Nais variabilis and Dero digitata (Annelida, Clitellata). Zoomorphology, 120(1), 39-46. doi: $10.1007 / 5004350000023$

Cakić, P., Petrović, Z., Kataranovski, D., Jakovčev, D. \& Lenhardt, M. 2000. The first record and description of Chaetogaster limnaei von Baer, 1827 (Naididae, Oligochaeta) on huso huso fry in Serbia. Helminthologia, 37(3), 162-164. Retrieved from: www.scopus.com

Campitelli-Ramos, R., Lucca, J.V., Oliveira, L.L.D., Marchese, M.R. \& Rocha, 0. 2014. First record of Dero (Aulophorus) Bimagnasetus harman (Oligochaeta) from Brazil and habitat characteristics. [Primeiro registro de Dero (Aulophorus) Bimagnasetus harman (Oligochaeta) do Brasil e notas ecológicas]. Brazilian Journal of Biology, 74(2), 483-488. doi: 10.1590/1519-6984.14512

Çapraz, S. \& Arslan, N. 2005. The Oligochaeta (Annelida) fauna of Aksu stream (Antalya). Turkish Journal of Zoology, 29(3), 229-236. Retrieved from: www.scopus.com

Carrasco Navarro, V., Brozinski, J.-., Leppänen, M.T., Honkanen, J.0., Kronberg, L. \& Kukkonen, J.V. 2011. Inhibition of pyrene biotransformation by piperonyl butoxide and identification of two pyrene derivatives in Lumbriculus variegatus (Oligochaeta). Environmental Toxicology and Chemistry, 30(5), 1069-1078. doi: 10.1002/etc.485

Carrasco Navarro, V., Leppänen, M.T., Honkanen, J.0. \& Kukkonen, J.V.K. 2012. Trophic transfer of pyrene metabolites and nonextractable fraction from oligochaete (Lumbriculus variegatus) to juvenile brown trout (Salmo Trutta). Chemosphere, 88(1), 55-61. doi: 10.1016/j. chemosphere.2012.02.060

Casellato, S. 1999. Oligochaetes of Karavasta Lagoon (Albania). Preliminary results. Hydrobiologia, 406, 175-182. doi: 10.1023/A:1003766527084

Casellato, S., Aiello, R. \& Negrisolo, P.A. 1992. Long-term experiment on Branchiura sowerbyi Beddard (Oligochaeta, Tubificidae) using sediment treated with LAS (Linear Alkylbenzene Sulphonate). Hydrobiologia, 232(2), 169-173. doi: $10.1007 /$ BF00017476

Casellato, S. \& Caneva, F. 1994. Composition and distribution of bottom oligochaete fauna of a north italian eutrophic lake (Lake Ledro). Hydrobiologia, 278(1-3), 87-92. doi: 10.1007/BF00142315

Casellato, S., Del Piero, S., Masiero, L. \& Covre, V. 2013. Fluoride toxicity and its effects on gametogenesis in the aquatic oligochaete Branchiura sowerbyi Beddard. Fluoride, 46(1), 7-18. Retrieved from: www.scopus.com

Cellot, B. \& Juget, J. 1998. Oligochaete drift in a large river (French Upper Rhône): The effect of life cycle and discharge. Hydrobiologia, 389(1-3), 183-191. Retrieved from: www.scopus.com

Ceretti, G. \& Nocentini, A.M. 1996. Notes on the distribution of some macrobenthonic populations (Oligochaeta and diptera Chironomidae) in the littoral of a few small lakes in northern Italy. Memorie - Istituto Italiano Di Idrobiologia, 54, 109-124. Retrieved from: www.scopus.com
César, I.I. 2014. Annelida (Oligochaeta and Aphanoneura) from the natural reserve of Isla Martín García (upper Río de la Plata Estuary, Argentina): Biodiversity and response to environmental variables. [Annelida (Oligochaeta e Aphanoneura) da reserva natural de usos múltiplos Ilha Martín García, Río de la Plata: Biodiversidade e reposta às variáveis ambientais]. Brazilian Journal of Biology, 74(1), 128-136. doi: 10.1590/1519-6984.21412

Chapman, K.K., Benton, M.J., Brinkhurst, R.0. \& Scheuerman, P.R. 1999. Use of the aquatic oligochaetes Lumbriculus variegatus and Tubifex tubifex for assessing the toxicity of copper and cadmium in a spiked-artificialsediment toxicity test. Environmental Toxicology, 14(2), 271-278. doi: 10.1002/(SICI)1522-7278(199905)14:2<271:AID-TOX8>3.0.C0;2-F

Chapman, P.M. \& Brinkhurst, R.0. 1987. Hair today, gone tomorrow: Induced chaetal changes in tubificid oligochaetes. Hydrobiologia, 155(1), 45-55. doi: $10.1007 / B F 00025630$

Chapman, P.M. \& Mitchell, D.G. 1986. Acute tolerance tests with the oligochaetes Nais communis (Naididae) and ilyodrilus frantzi (Tubificidae). Hydrobiologia, 137(1), 61-64. doi: 10.1007/BF00004173

Chauvet, E., Giani, N. \& Gessner, M.0. 1993. Breakdown and invertebrate colonization of leaf litter in two contrasting streams: Significance of oligochaetes in a large river. Canadian Journal of Fisheries and Aquatic Sciences, 50(3), 488-495. doi: 10.1139/f93-057

Chen, J. \& Xie, P. 2008. Accumulation of hepatotoxic microcystes in freshwater mussels, aquatic insect larvae and oligochaetes in a large, shallow eutrophic lake (LakeChaohu) of subtropical China. Fresenius Environmental Bulletin, 17(7 A), 849-854. Retrieved from: www.scopus.com

Christensen, B. \& Theisen, B.F. 1998. Phylogenetic status of the family Naididae (Oligochaeta, Annelida) as inferred from DNA analyses. Journal of Zoological Systematics and Evolutionary Research, 36(4), 169-172. Retrieved from: www.scopus.com

Christoffersen, M.L. 2012. Checklist of questidae (Clitellata) and aeolosomatidae (Oligochaeta) from South America. Turkish Journal of Zoology, 36(1), 133-138. doi: 10.3906/z00-1002-26

Ciparis, S. \& Hale, R.C. 2005. Bioavailability of polybrominated diphenyl ether flame retardants in biosolids and spiked sediment to the aquatic oligochaete, Lumbriculus variegatus. Environmental Toxicology and Chemistry, 24(4), 916-925. doi: 10.1897/04-179R.1

Coastes, K.A. 1987. Phylogenetics of some Enchytraeidae (Annelida: Oligochaeta): A preliminary investigation of relationships to the Haplotaxidae. Hydrobiologia, 155(1), 91-106. doi: 10.1007/BF00025634

Coates, K.A. \& Stacey, D.F. 1994. Oligochaetes (Naididae, Tubificidae, Enchytraeidae and Alluroididae) of Guyana, Peru and Ecuador. Hydrobiologia, 278(1-3), 79-84. doi: 10.1007/BF00142313

Collado, R. \& De Mendoza, G. 2009. Environmental factors and distribution of littoral oligochaetes in pyrenean lakes. doi: 10.1127/advlim/62/2009/215. Retrieved from: www.scopus.com

Collado, R., Kasprzak, P.\& Schmelz, R.M. 1999. Oligochaeta and Aphanoneura in two northern german hardwater lakes of different trophic state. Hydrobiologia, 406, 143-148. doi: 10.1023/A:1003700604272

Collado, R., Martínez-Ansemil, E. \& Giani, N. 1993. The aquatic oligochaetes of the iberain peninsula: Description of Stylodrilus curvithecus sp. nov. (Lumbriculidae) and Mesenchytraeus lusitanicus sp. nov., with a redescription of cognettia hibernica healy (Enchytraeidae). [Les Oligochètes aquatiques de la Péninsule lbérique: Description de Stylodrilus curvithecus sp. nov. (Lumbriculidae) et de Mesenchytraeus lusitanicus sp. nov. et redescription de Cognettia hibernica Healy (Enchytraeidae)]. Annales de Limnologie, 29(2), 129-138. doi: 10.1051/limn/1993012

Collado, R. \& Schmelz, R.M. 2001. Oligochaete distribution patterns in two german hardwater lakes of different trophic state. Limnologica, 31(4), 317-328. Retrieved from: www.scopus.com 
Collado, R. \& Schmelz, R.M. 2000. Pedonais crassifaucis gen. nov., sp. nov. (Naididae) and Bothrioneurum righii sp. nov. (Tubificidae), two new tropical soil-dwelling species of "aquatic" oligochaetes (Clitellata, Annelida) from central amazonia. Amazoniana, 16(1-2), 223-235. Retrieved from: www.scopus.com

Collado, R. \& Schmelz, R.M. 2000. Pristina silvicola and Pristina terrena sp. nov., two new soil-dwelling species of Naididae (Oligochaeta, Annelida) from the tropical rain forest near Manaus, Brazil, with comments on the genus Pristinella. Journal of Zoology, 251(4), 509-516. doi: 10.1017/ $\underline{\mathrm{S} 0952836900008104}$

Conn, D.B., Ricciardi, A., Babapulle, M.N., Klein, K.A. \& Rosen, D.A. 1996. Chaetogaster limnaei (Annelida: Oligochaeta) as a parasite of the zebra mussel dreissena polymorpha, and the quagga mussel dreissena bugensis (Mollusca: Bivalvia). Parasitology Research, 82(1), 1-7. doi: $\underline{10.1007 / 5004360050058}$

Connell, D.W., Bowman, M. \& Hawker, D.W. 1988. Bioconcentration of chlorinated hydrocarbons from sediment by oligochaetes. Ecotoxicology and Environmental Safety, 16(3), 293-302. doi: 10.1016/0147-6513(88)90058-9

Conrad, A.U., Comber, S.D. \& Simkiss, K. 2000. New method for the assessment of contaminant uptake routes in the oligochaete Lumbriculus variegatus. Bulletin of Environmental Contamination and Toxicology, 65(1), 16-21. doi: $10.1007 / 5001280000088$

Corbi, J.J., Roque, F.O., Trivinho-Strixino, S. \& Alves, R.G. 2005. Records of oligochaetes in freshwater sponges, on bryozoans, and on colonial hydrozoans from Brazil. Brazilian Journal of Biology - Revista Brasleira de Biologia, 65(1), 187-188. doi: 10.1590/S1519-69842005000100022

Cortelezzi, A., Armendáriz, L.C., van Oosterom, M.V.L., Cepeda, R. \& Capítulo, A.R. 2011. Different levels of taxonomic resolution in bioassessment: A case study of Oligochaeta in lowland streams. [Diferentes níveis de resolução taxonômica em biomonitoramento: Um estudo de caso de oligoquetados em rios de planícies]. Acta Limnologica Brasiliensia, 23(4), 412-425. Retrieved from: www.scopus.com

Courtney, C.C. \& Christensen, B.M. 1988. Host-parasite relationships of caryophyllaeid cestodes and aquatic oligochaetes. II. Effects of host age and mixed infections. Journal of Parasitology, 74(4), 573-581. doi: $\underline{10.2307 / 3282172}$

Croce, V., De Angelis, S., Patrolecco, L., Polesello, S. \& Valsecchi, S. 2005. Uptake and accumulation of sediment as sociated 4-nonylphenol in a benthic invertebrate (Lumbriculus variegatus, freshwater oligochaete). Environmental Toxicology and Chemistry, 24(5), 1165-1171. doi: 10.1897/04-337R.1

Cui, Y. \& Wang, H. 2009. Three new species of Tubificinae, Oligochaeta, from two plateau lakes in southwest China. Zootaxa, (2143), 45-54. Retrieved from: www.scopus.com

Cui, Y.-. \& Wang, H.-. 2005. Potamothrix scleropenis sp. nov. (Oligochaeta: Tubificidae) from Fuxian Lake, the deepest lake in southwest China. Zoological Science, 22(12), 1353-1357. doi: 10.2108/zsj.22.1353

Dafoe, L.T., Rygh, A.L., Yang, B., Gingras, M.K. \& Pemberton, S.G. 2011. A new technique for assessing tubificid burrowing activities, and recognition of biogenic grading formed by these oligochaetes. Palaios, 26(1), 66-80. doi: 10.2110/pal0.2010.p10-023r

Danijela, S., Radujković, B.M. \& Krpo-Ćetković, J. 2011. Catalogue of aquatic Oligochaeta (Annelida: Clitellata) of Montenegro, exclusive of Naidinae and Pristininae. Zootaxa, (2985), 1-25. Retrieved from: www.scopus.com

de Eguileor, M., Valvassori, R., Lanzavecchia, G. \& Giorgi, S. 1990. Body wall muscles in the haplotaxids Haplotaxis gordioides and Pelodrilus leruthi (Annelida, Oligochaeta). Zoomorphology, 110(1), 27-36. doi: 10.1007/ BF01632809

De Jonge, M., Eyckmans, M., Blust, R. \& Bervoets, L. 2011. Are accumulated sulfide-bound metals metabolically available in the benthic oligochaete
Tubifex tubifex? Environmental Science \& Technology, 45(7), 3131-3137. doi: $10.1021 /$ es 1037595

de Pascar, C.G. 1987. Aquatic Oligochaeta in some tributaries of the Río de la Plata, Buenos Aires, Argentina. Hydrobiologia, 144(2), 125-130. doi: 10.1007/BF00014526

Deeds, J.R. \& Klerks, P.L. 1999. Metallothionein-like proteins in the freshwater oligochaete Limnodrilus udekemianus and their role as a homeostatic mechanism against cadmium toxicity. Environmental Pollution, 106(3), 381-389. doi: 10.1016/50269-7491(99)00100-1

Des Châtelliers, M.C., Juget, J., Lafont, M. \& Martin, P. 2009. Subterranean aquatic Oligochaeta. Freshwater Biology, 54(4), 678-690. doi: 10.1111/j.1365-2427.2009.02173.x

Di Maio, J. \& Stacey, D.F. 1998. New distribution records of aquatic Oligochaeta (Annelida) from running waters in Ontario. Canadian Field-Naturalist, 112(1), 69-74. Retrieved from: www.scopus.com

Ding, J., Drewes, C.D. \& Hsu, W.H. 2001. Behavioral effects of ivermectin in a freshwater oligochaete, Lumbriculus variegatus. Environmental Toxicology and Chemistry, 20(7), 1584-1590. doi: 10.1002/etc.5620200724

Dózsa-Farkas, K. 1996. An interesting reproduction type in enchytraeids (Oligochaeta). Acta Zoologica Academiae Scientiarum Hungaricae, 42(1), 3-10. Retrieved from: www.scopus.com

Dózsa-Farkas, K. 2009. Review of the fridericia species (Oligochaeta: Enchytraeidae) possessing two spermathecal diverticula and description of a new species. Journal of Natural History, 43(17-18), 1043-1065. doi: $\underline{10.1080 / 00222930902767441}$

Dózsa-Farkas, K. 2010. Significance of using nephridia in the taxonomy of family Enchytraeidae: (Annelida: Oligochaeta). Zoology in the Middle East, 51, 41-53. doi: 10.1080/09397140.2010.10638456

Dumnicka, E. 2004. A description of Cernosvitoviella tridentina, a new species of Enchytraeidae (Oligochaeta) from the italian alps. Annales de Limnologie, 40(2), 133-137. doi: 10.1051/limn/2004011

Dumnicka, E. 1998. A new species of fridericia (Oligochaeta: Enchytraeidae) found in a spring in the sudety mountains (Poland). Annales de Limnologie, 34(2), 155-158. doi: 10.1051/limn/1998014

Dumnicka, E. 1994. Communities of oligochaetes in mountain streams of Poland. Hydrobiologia, 278(1-3), 107-110. doi: 10.1007/BF00142317

Dumnicka, E. 2006. Composition and abundance of oligochaetes (Annelida: Oligochaeta) in springs of KrakóW-CzȩStochowa upland (southern Poland): Effect of spring encasing and environmental factors. Polish Journal of Ecology, 54(2), 231-242. Retrieved from: www.scopus.com

Dumnicka, E. 1986. Ecology of some waters in the forest-agricultural basin of the River Brynica near the upper Silesian industrial region. 9. Communities of oligochaetes. Acta Hydrobiologica, 27(4), 535-545. Retrieved from: www.scopus.com

Dumnicka, E. 1994. Habitat preferences of invertebrates (especially Oligochaeta) in a stream. Acta Hydrobiologica, 36(1), 91-101. Retrieved from: www.scopus.com

Dumnicka, E. 2009. New for Poland tubificid (Oligochaeta) species from karstic springs. Polish Journal of Ecology, 57(2), 395-401. Retrieved from: www.scopus.com

Dumnicka, E. 2014. Stygobitic oligochaetes (Annelida, Clitellata) in Poland with remarks on their distribution in central europe. Subterranean Biology, 14(1), 15-24. doi: $10.3897 /$ subtbiol. 14.7700

Dumnicka, E. 1987. The effect of dam reservoirs on oligochaete communities in the River Dunajec (southern Poland). Acta Hydrobiologica, 29(1), 25-34. Retrieved from: www.scopus.com

Dumnicka, E. 2010. Two new freshwater enchytraeid species (Oligochaeta) from the italian alps. Italian Journal of Zoology, 77(1), 38-43. doi: $\underline{10.1080 / 11250000902855505}$ 
Dumnicka, E. 2002. Upper Vistula River: Response of aquatic communities to pollution and impoundment. X. oligochaete taxocens. Polish Journal of Ecology, 50(2), 237-247. Retrieved from: www.scopus.com

Dumnicka, E. \& Boggero, A. 2007. Freshwater Oligochaeta in two mountain ranges in europe: The tatra mountains (Poland) and the alps (Italy). Fundamental and Applied Limnology, 168(3), 231-242. doi: 10.1127/1863-9135/2007/0168-0231

Dumnicka, E. \& Galas, J. 2002. Factors affecting the distribution of Oligochaeta in small high mountain ponds (Tatra Mountains, Poland). Archiv Fur Hydrobiologie, 156(1), 121-133. doi: 10.1127/0003-9136/2002/01560121

Dumnicka, E. \& Galas, J. 2012. Temporal changes in oligochaete fauna of three alpine ponds in the Tatra Mountains (Poland). Boreal Environment Research, 17(3-4), 252-262. Retrieved from: www.scopus.com

Dumnicka, E. \& Koszałka, J. 2005. The effect of drought on Oligochaeta communities in small woodland streams. Biologia - Section Zoology, 60(2), 143-150. Retrieved from: www.scopus.com

Dumnicka, E. \& Krodkiewska, M. 2003. Studies on freshwater Oligochaeta in the upper Silesia region (southern Poland). Biologia - Section Zoology, 58(5), 897-902. Retrieved from: www.scopus.com

Dumnicka, E. \& Kukula, K. 1990. The communities of oligochaetes of the wolosatka and terebowiec streams (the Bieszczady National Park, southeastern Poland). Acta Hydrobiologica, 32(3-4), 423-435. Retrieved from: www.scopus.com

Dumnicka, E. \& Poznańska, M. 2006. Novel polish recordings of rare aquatic Oligochaeta species. Oceanological and Hydrobiological Studies, 35(2), 111-120. Retrieved from: www.scopus.com

Dumnicka, E., Steingruber, S., Colombo, L., Zaupa, S. \& Boggero, A. 2015. Oligochaete assemblages of swiss alpine lakes. Italian Journal of Zoology, 82(1), 112-123. doi: $10.1080 / 11250003.2014 .965230$

El-Mansy, A., Molnár, K. \& Székely, C. 1998. Development of Myxobolus portucalensis saraiva and molnar, 1990 (Myxosporea: Myxobolidae) in the oligochaete Tubifex tubifex (Müller). Systematic Parasitology, 41(2), 95-103. doi: 10.1023/A:1006034527844

El-Matbouli, M., McDowell, T.S., Antonio, D.B., Andree, K.B. \& Hedrick, R.P. 1999. Effect of water temperature on the development, release and survival of the triactinomyxon stage of Myxobolus cerebralis in its oligochaete host. International Journal for Parasitology, 29(4), 627-641. doi: 10.1016/S0020-7519(99)00009-0

Erickson, R.J., Ankley, G.T., Defoe, D.L., Kosian, P.A. \& Makynen, E.A. 1999. Additive toxicity of binary mixtures of phototoxic polycyclic aromatic hydrocarbons to the oligochaete Lumbriculus variegatus. Toxicology and Applied Pharmacology, 154(1), 97-105. doi: 10.1006/taap.1998.8563

Erséus, C. 1990. Cladistic analysis of the subfamilies within the Tubificidae (Oligochaeta). Zoologica Scripta, 19(1), 57-63. doi: 10.1111/j.14636409.1990.tb00240.x

Erséus, C. 1987. Phylogenetic analysis of the aquatic Oligochaeta under the principle of parsimony. Hydrobiologia, 155(1), 75-89. doi: 10.1007/ BF00025633

Erséus, C. 2005. Phylogeny of oligochaetous Clitellata. Hydrobiologia, 535(1), 357-372. doi: $10.1007 / \mathrm{s} 10750-004-4426-x$

Erséus, C., Envall, I., Marchese, M. \& Gustavsson, L. 2010. The systematic position of opistocystidae (Annelida, Clitellata) revealed by DNA data. Molecular Phylogenetics and Evolution, 54(1), 309-313. doi: 10.1016/j. ympev.2009.09.037

Erséus, C. \& Grimm, R. 2002. A new species of ainudrilus (Tubificidae) from south Georgia, and other subantarctic freshwater oligochaetes. Hydrobiologia, 468, 77-81. doi: 10.1023/A:1015249024244

Erséus, C. \& Källersjö, M. 2004. 18S rDNA phylogeny of Clitellata (Annelida). ZoologicaScripta,33(2), 187-196.doi:10.1111/j.1463-6409.2004.00146.X
Erséus, C. \& Paoletti, A. 1986. An italian record of the aquatic oligochaete Monopylephorus limosus (Tubificidae), previously known only from Japan and China. Bollettino di Zoologia, 53(1), 115-118. doi: 10.1080/11250008609355492

Erséus, C., Rota, E., Matamoros, L. \& De Wit, P. 2010. Molecular phylogeny of Enchytraeidae (Annelida, Clitellata). Molecular Phylogenetics and Evolution, 57(2), 849-858. doi: 10.1016/j.ympev.2010.07.005

Erséus, C., Rota, E., Timm, T., Grimm, R., Healy, B. \& Lundberg, S. 2005. Riverine and riparian clitellates of three drainages in southern Sweden. Annales de Limnologie, 41(3), 183-194. doi: 10.1051/limn:20054130183

Erséus, C. \& Sang, Q. 1985. Two aberrant Tubificidae (Oligochaeta) from Pearl River in the people's Republic of China. Hydrobiologia, 127(3), 193-196. doi: $10.1007 / \mathrm{BF} 00000001$

Eszterbauer, E., Székely, C., Molnár, K. \& Baska, F. 2000. Development of Myxobolus bramae (Myxosporea: Myxobolidae) in an oligochaete alternate host, Tubifex tubifex. Journal of Fish Diseases, 23(1), 19-25. doi: 10.1046/j.1365-2761.2000.00202.x

Ewald, G., Berglund, 0.\& Svensson, J.M. 1997. Effect of oligochaete bioturbation on sediment accumulation of 2,2,4,4'-tetrachlorobiphenyl. Ecotoxicology and Environmental Safety, 36(1), 66-71. doi: 10.1006/eesa.1996.1489

Falci Theza Rodrigues, L., Jabour Vescovi Rosa, B.F., Lobo, H., Campos Divino, A. \& Da Gama Alves, R. 2015. Diversity and distribution of oligochaetes in tropical forested streams, southeastern Brazil. Journal of Limnology, 74(3), 433-443. doi: $10.4081 /$ jlimnol.2015.1024

Famme, P. \& Knudsen, J. 1985. Aerotaxis by the freshwater oligochaete Tubifex sp. Oecologia, 65(4), 599-601. doi: 10.1007/BF00379679

Fend, S.V., Rodriguez, P. \& Lenat, D.R. 2015. Uktena riparia gen. nov., sp. nov. (Annelida, Clitellata, Lumbriculidae), a new spermatophore-producing oligochaete. Zootaxa, 3994(3), 411-424. doi:10.11646/zootaxa.3994.3.5

Ferraguti, M. 1985. Slanted centriole and transient anchoring apparatus during spermiogenesis of an oligochaete (Annelida). Biology of the Cell, 52(2), 175-180. doi: 10.1111/j.1768-322X.1985.tb00334.x

Ferraguti, M., Bernardini, G., Melone, G. \& Dallai, R. 1988. Structure and function of the metachronal wave in Tubifex Tubifex spermatozeugmata (Annelida, Oligochaeta). Journal of Ultrastructure Research and Molecular Structure Research, 99(1), 79-95. doi: 10.1016/0889-1605(88)90035-3

Ferraguti, M. \& Erséus, C. 1999. Sperm types and their use for a phylogenetic analysis of aquatic clitellates. Hydrobiologia, 402, 225-237. doi: 10.1023/A:1003752811830

Ferraguti, M., Erséus, C., Kaygorodova, I. \& Martin, P. 1999. New sperm types in Naididae and Lumbriculidae (Annelida: Oligochaeta) and their possible phylogenetic implications. Hydrobiologia, 406, 213-222. doi: 10.1023/A:1003708906089

Ferraguti, M., Erséus, C. \& Pinder, A. 1996. The spermatozoon of capilloventer australis and the systematic position of the capilloventridae (Annelida: Oligochaeta). Australian Journal of Zoology, 44(5), 469-478. doi: 10.1071/Z09960469

Ferraguti, M., Fascio, U. \& Boi, S. 2002. Mass production of basal bodies in paraspermiogenesis of Tubificinae (Annelida, Oligochaeta). Biology of the Cell, 94(2), 109-115. doi: 10.1016/S0248-4900(02)01185-1

Finder, A.M., Hill, B.D. \& Green, P.E. 1998. A new species of Dero (Allodero) (Naididae: Oligochaeta) inhabiting the wolffian ducts of the green tree frog (Litoria caerulea) in Queensland. Memoirs of the Queensland Museum, 42(2), 559-564. Retrieved from: www.scopus.com

Finogenova, N.P. \& Lobasheva, T.M. 1987. Growth of Tubifex tubifex Müller (Oligochaeta, Tubificidae) under various trophic conditions. Internationale Revue Der Gesamten Hydrobiologie Und Hydrographie, 72(6), 709-726. doi: $10.1002 /$ iroh. 19870720608

Fisher, S.W., Chordas III, S.W. \& Landrum, P.F. 1999. Lethal and sublethal body residues for $P C B$ intoxication in the oligochaete, Lumbriculus 
variegatus. Aquatic Toxicology, 45(2-3), 115-126. doi: $10.1016 / 50166-$ 445X(98)00103-9

Fisk, A.T., Wiens, S.C., Barrie Webster, G.R., Bergman, Å. \& Muir, D.C.G. 1998. Accumulation and depuration of sediment-sorbed (12- and C16polychlorinated alkanes by oligochaetes (Lumbriculus variegatus). Environmental Toxicology and Chemistry, 17(10), 2019-2026. doi: 10.1897/1551-5028(1998)017<2019:AADOSS > 2.3.C0;2

Flores-Tena, F.J. \& Martínez-Tabche, L. 2001. The effect of chromium on the hemoglobin concentration of Limnodrilus hoffmeisteri (Oligochaeta: Tubificidae). Ecotoxicology and Environmental Safety, 50(3), 196-202. doi: 10.1006/eesa.2001.2104

Florou, H., Tsytsugina, V., Polikarpov, G.G., Vosniakos, F.K. \& Evangeliou, N. 2009. A comparative study on genotoxic effects in Oligochaeta from areas with elevated natural and artificial radioactivity. Journal of Environmental Protection and Ecology, 10(3), 807-814. Retrieved from: www.scopus.com

Gabric, A.J., Connell, D.W. \& Bell, P.R.F. 1990. A kinetic model for bioconcentration of lipophilic compounds by oligochaetes. Water Research, 24(10), 1225-1231. doi: 10.1016/0043-1354(90)90045-8

Gainutdinov, M.K., Kalinnikova, T.B., Gainutdinov, T.M. \& Yargunov, V.G. 2002. Self-regulation of Oligochaetan worm organisms by their chemical signals effused by them. Journal of Evolutionary Biochemistry and Physiology, 38(3), 364-366. doi: 10.1023/A:1020701130402

Gelder, S.R. 1989. Histophysiology of digestion and observations on the structure of the alimentary canal in the ectosymbiont Chaetogaster limnaei limnaei Baer, 1827 (Annelida: Oligochaeta). Hydrobiologia, 180(1), 115-125. doi: 10.1007/BF00027544

Gerhardt, A. 2007. Importance of exposure route for behavioural responses in Lumbriculus variegatus Müller (Oligochaeta: Lumbriculida) in shortterm exposures to PB. Environmental Science \& Pollution Research, 14(6), 430-434. doi: 10.1065/espr2006.12.371

Gerhardt, A. 2009. Screening the toxicity of $\mathrm{NI}, \mathrm{CD}, \mathrm{CU}$, ivermectin, and imidacloprid in a short-term automated behavioral toxicity test with Tubifex tubifex (Müller, 1774) (Oligochaeta). Human and Ecological Risk Assessment, 15(1), 27-40. doi: 10.1080/10807030802614983

Giani, N., Martin, P. \& Juget, J. 1995. A new species of Phreodrilidae (Oligochaeta), Astacopsidrilus naceri sp. nov., from Morocco (north africa), with notes on the biogeography of the family. Canadian Journal of Zoology, 73(12), 2375-2381. doi: 10.1139/z95-277

GIANI, N. \& RODRIGUEZ, P. 1994. New species of the genus trichodrilus (Oligochaeta, Lumbriculidae). Zoologica Scripta, 23(1), 33-41. doi: 10.1111/j.1463-6409.1994.tb00371.x

Giani, N., Sambugar, B., Martínez-Ansemil, E., Martin, P. \& Schmelz, R.M. 2011. The groundwater oligochaetes (Annelida, Clitellata) of Slovenia. Subterranean Biology, 9(1), 85-102. doi: 10.3897/subtbiol.9.2512

Gilbert, M.A. \& Granath Jr., W.0. 2008. Susceptibility of Tubifex tubifex (Annelida: Oligochaeta: Tubificidae) from the rock creek drainage of west central Montana, USA, to Myxobolus cerebralis (Myxozoa: Myxosporea: Myxobolidae), the causative agent of salmonid whirling disease. Comparative Parasitology, 75(1), 92-97. doi: 10.1654/4310.1

Gillis, P.L., Diener, L.C., Reynoldson, T.B. \& Dixon, D.G. 2002. Cadmiuminduced production of a metallothioneinlike protein in Tubifex tubifex (Oligochaeta) and Chironomus riparius (Diptera): Correlation with reproduction and growth. Environmental Toxicology and Chemistry, 21(9), 1836-1844. Retrieved from: www.scopus.com

Gillis, P.L., Reynoldson, T.B. \& Dixon, D.G. 2006. Metallothionein-like protein and tissue metal concentrations in invertebrates (Oligochaetes and (hironomids) collected from reference and metal contaminated field sediments. Journal of Great Lakes Research, 32(3), 565-577. doi: 10.3394/0380-1330(2006)32[565:MPATMC]2.0.C0;2
Gluzman, C. 1990. A new species of the freshwater genus allonais (Oligochaeta, Naididae) from among the roots of Eichhornia crassipes (Argentina). Studies on Neotropical Fauna and Environment, 25(3), 121-124. doi: 10.1080/01650529009360811

Gluzman, C. 1997. Sperm cells in Aeolosoma marcusi (Annelida, Oligochaeta). Biocell, 21(2), 137-142. Retrieved from: www.scopus.com

Gluzman, C. 1998. Ultrastructural study of the spermiogenesis in two species of Naididae, paranais litoralis and Nais communis (Annelida, Oligochaeta). Biocell, 22(2), 141-148. Retrieved from: www.scopus.com

Gluzmán, C. 1999. The spermatozoon of Slavina appendiculata (Annelida, Oligochaeta). Biocell, 23(2), 97-102. Retrieved from: www.scopus.com

Gnaiger, E., Kaufmann, R. \& Staudigl, I. 1987. Physiological reactions of aquatic oligochaetes to environmental anoxia. Hydrobiologia, 155(1), 155. doi: $10.1007 / \mathrm{BF} 00025641$

Goretti, E., Marcucci, C., Di Veroli, A., Fabrizi, A. \& Gaino, E. 2014. The Tubificids (Annelida, Oligochaeta) of Lake Trasimeno and Lake Piediluco in central Italy, with a study of SEM morphology of some species. Turkish Journal of Zoology, 38(3), 334-341. doi: 10.3906/z00-1308-40

Gorni, G., Peiro, D.F. \& Sanches, N. 2015. Aquatic Oligochaeta (Annelida: (litellata) from state of São Paulo, Brazil: Diversity and occurrence review. [Oligochaeta aquático (Annelida: Clitellata) do estado de São Paulo: revisão da diversidade e ocorrência]. Biota Neotropica, 15(1), 1-8. doi: 10.1590/1676-06032015006314

Gorni, G.R. \& Alves, R.D.G. 2007. Naididae (Annelida, Oligochaeta) associated with briophytes in Brotas, state of São Paulo, Brazil. Revista Brasileira de Zoologia, 24(2), 518-519. doi: 10.1590/50101-81752007000200036

Gorni, G.R.\&Alves, R.D.G. 2006. Naididae (Annelida, Oligochaeta) associated with Pomacea bridgesii (Reeve) (Gastropoda, Ampullaridae). Revista Brasileira de Zoologia, 23(4), 1059-1061. doi: 10.1590/50101-81752006000400011

Gorni, G.R. \& Alves, R.G. 2008. Oligochaeta (Annelida: Clitellata) in headwater streams of the Parque Estadual de Campos do Jordão (São Paulo, Brazil). [Oligochaeta (Annelida: Clitellata) em córregos de baixa ordem do Parque Estadual de Campos do Jordão (São Paulo, Brasil)]. Biota Neotropica, 8(4), 161-165. Retrieved from: www.scopus.com

Gorni, G.R. \& Alves, R.G. 2012. Oligochaetes (Annelida, Clitellata) in a neotropical stream: A mesohabitat approach. [Oligoquetos (Annelida, (litellata) em um córrego neotropical: Uma abordagem do mesohabitat]. Iheringia - Série Zoologia, 102(1), 106-110. doi: 10.1590/5007347212012000100015

Grabowski, M. \& Jabłońska, A. 2009. First records of Branchiura sowerbyi Beddard, 1892 (Oligochaeta: Tubificidae) in greece. Aquatic Invasions, 4(2), 365-367. doi: 10.3391/ai.2009.4.2.10

Granath Jr., W.0. \& Gilbert, M.A. 2002. The role of Tubifex tubifex (Annelida: Oligochaeta: Tubificidae) in the transmission of Myxobolus cerebralis (Myxozoa: Myxosporea: Myxobolidae). American Fisheries Society Symposium, 2002(29), 79-85. Retrieved from: www.scopus.com

Gregory, T.R. \& Hebert, P.D.N. 2002. Genome size estimates for some oligochaete annelids. Canadian Journal of Zoology, 80(8), 1485-1489. doi: $10.1139 /$ Z02-145

Grimm, R. 1987. Contributions towards the taxonomy of the african Naididae (Oligochaeta). IV. Zoogeographical and taxonomical considerations on african Naididae. Hydrobiologia, 155(1), 27-37. doi: 10.1007/ BF00025628

Groh, S., Claus, E., Manz, W., Möhlenkamp, C., Immermann, R.-. \& BlübaumGronau, E. 2010. Influence of increasing sediment organic matter on reproduction and growth of the benthic oligochaete Lumbriculus variegates. [Einfluss organischer substanz auf die reproduktion, biomasse und akkumulation hydrophober schadstoffe in Lumbriculus variegatus]. Umweltwissenschaften Und Schadstoff-Forschung, 22(2), 99-106. doi: 10.1007/s12302-010-0115-8 
Guérin, C. \& Labroue, L. 1991. A laboratory study of the effect of Tubifex tubifex Müll. (Tubificidae, Oligochaeta) on the release of phosphorus through the sediment. [Etude expérimentale de l'influence de Tubifex tubifex Müll. (Tubificidae, Oligochaeta) sur le relargage du phosphore par le sédiment]. Annales de Limnologie, 27(3), 253-265. doi: 10.1051/ limn/1991019

Gupta, R.K., Kumar, S., Gorai, A.C. \& Pandey, P.N. 1998. Oligochaetes in a freshwater pond in dhanbad. Ecology, Environment and Conservation, 4(3), 123-126. Retrieved from: www.scopus.com

Gust, K.A. \& Fleeger, J.W. 2006. Exposure to cadmium-phenanthrene mixtures elicits complex toxic responses in the freshwater tubificid oligochaete, llyodrilus templetoni. Archives of Environmental Contamination and Toxicology, 51(1), 54-60. doi: 10.1007/s00244-005-1075-7

Gustavsson, L.M. 2001. Comparative study of the cuticle in some aquatic oligochaetes (Annelida: Clitellata). Journal of Morphology, 248(2), 185-195. doi: 10.1002/jmor.1029

Gustavsson, L.M. \& Erséus, C. 1997. Morphogenesis of the genital ducts and spermathecae in Clitellio arenarius, Heterochaeta costata, Tubificoides benedii (Tubificidae) and Stylaria lacustris (Naididae) (Annelida, Oligochaeta). Acta Zoologica, 78(1), 9-31. doi: 10.1111/j.14636395.1997.tb01122.x

Gustavsson, L.M. \& Erséus, C. 1999. Morphology and phylogenetic implications of oesophageal modifications in the limnodriloidinae (Oligochaeta, Tubificidae). Journal of Zoology, 248(4), 467-482. doi: 10.1017/S0952836999008067

Hallett, S.L., Atkinson, S.D. \& Bartholomew, J.L. 2005. Countering morphological ambiguities: Development of a PCR assay to assist the identification of Tubifex tubifex oligochaetes. Hydrobiologia, 543(1), 305-309. doi: 10.1007/s10750-004-6954-9

Hartwich, G. \& Kilias, I. 1989. Die Oligochaeten-Typen des zoologischen museums in berlin. Mitteilungen Aus Dem Museum Für Naturkunde in Berlin - Zoologisches Museum Und Institut Für Spezielle Zoologie (Berlin), 65(2), 249-295. doi: 10.1002/mmnz.19890650210

He, X., Cui, Y. \& Wang, H. 2010. Limnodrilus simplex sp. nov. (Oligochaeta: Naididae: Tubificinae) from Changjiang River, China. Zoological Science, 27(9), 768-770. doi: $10.2108 /$ zsj. 27.768

Healy, B. 1987. The depth distribution of Oligochaeta in an Irish quaking marsh. Hydrobiologia, 155(1), 235-247. doi: 10.1007/BF00025656

Healy, B. \& Coates, K.A. 1999. Finding enchytraeid oligochaetes (Clitellata) in hot climates: Species occurrence on the shores of Bermuda. Hydrobiologia, 406, 111-117. doi: 10.1023/A:1003760922928

Healy, B. \& Fend, S. 2002. The occurrence of mesenchytraeus (Enchytraeidae: Oligochaeta) in riffle habitats of north-west american rivers, with description of a new species. Journal of Natural History, 36(1), 15-23. doi: 10.1080/713833842

Hegde, P.R. \& Sreepada, K.S. 2015. Freshwater oligochaetes (Annelida) from western ghats and the west Coast of Karnataka (India). Turkish Journal of Zoology, 39(3), 523-526. doi: 10.3906/zo0-1311-46

Higgins, C.P., Mcleod, P.B., Macmanus-Spencer, L.A. \& Luthy, R.G. 2007. Bioaccumulation of perfluorochemicals in sediments by the aquatic oligochaete Lumbriculus variegatus. Environmental Science \& Technology, 41(13), 4600-4606. doi: $10.1021 /$ es 0627920

Hipp, E., Bickel, U., Mustafa, T. \& Hoffmann, K.H. 1986. Integumentary uptake of acetate and propionate (VFA) by Tubifex sp., a freshwater oligochaete. II. Role ofVFA as nutritional resources and effects of anaerobiosis. Journal of Experimental Zoology, 240(3), 299-308. doi: 10.1002/jez.1402400303

Hipp, E., Mustafa, T., Bickel, U. \& Hoffmann, K.H. 1986. Integumentary uptake of acetate and propionate (VFA) by Tubifex sp., a freshwater oligochaete. I. Uptake rates and transport kinetics. Journal of Experimental Zoology, 240(3), 289-297. doi: 10.1002/jez.1402400302
Hipp, E., Mustafa, T. \& Hoffmann, K.H. 1985. Integumentary uptake of volatile fatty acids by the freshwater oligochaete Tubifex. Naturwissenschaften, 72(3), 148-149. doi: 10.1007/BF00490402

Hirabayashi, K., Oga, K., Yoshizawa, K., Yoshida, N. \& Kazama, F. 2012. A longterm eutrophication process observed from the changes in the horizontal distribution of profundal oligochaete fauna in mesotrophic-eutrophic Lake Kawaguchi, Japan. Turkish Journal of Zoology, 36(1), 39-46. doi: 10.3906/200-0912-18

Hoffmann, H., Hipp, E. \& Sedlmeier, U.A. 1987. Aerobic and anaerobic metabolism of the freshwater oligochaete Tubifex sp. Hydrobiologia, 155(1), 157-158. doi: 10.1007/BF00025642

Hoffmann, K.H. \& Wulf, A. 1993. Comparative studies of integumentary uptake of short-chain carboxylic acids by freshwater oligochaetes. Comparative Biochemistry and Physiology - Part A: Physiology, 104(1), 169-174. doi: 10.1016/0300-9629(93)90025-Y

Huang, T.-., Nie, X.-., Zhang, J.-., Li, W., Li, X.-., Zhang, S. \& Wang, B.-. 2010. Study on migration modes and correlative factors of Tubifex tubifex (Oligochaeta, Tubificidae) in source water. Water Science and Technology: Water Supply, 10(6), 887-895. doi: 10.2166/ws.2010.503

Hyötyläinen, T. \& Oikari, A. 2004. Bioaccumulation of PAHs from creosotecontaminated sediment in a laboratory-exposed freshwater oligochaete, Lumbriculus variegatus. Chemosphere, 57(2), 159-164. doi: 10.1016/j. chemosphere.2004.05.001

Ibrahim, M.M. 2007. Population dynamics of Chaetogaster limnaei (Oligochaeta: Naididae) in the field populations of freshwater snails and its implications as a potential regulator of trematode larvae community. Parasitology Research, 101(1), 25-33. doi: 10.1007/ s00436-006-0436-0

Ilyashuk, B.P. 1999. Littoral oligochaete (Annelida: Oligochaeta) communities in neutral and acidic lakes in the Republic of Karelia, Russia. Boreal Environment Research, 4(3), 277-284. Retrieved from: www.scopus.com

Irmler, U. 1989. Population-ecology and migration of Dero multibranchiata stieren, 1892 (Naididae, Oligochaeta) in the central amazon inundation forest. Amazoniana, 11(1), 31-52. Retrieved from: www.scopus.com

Jabłońska, A. 2014. Oligochaete communities of highly degraded urban streams in Poland, central europe. North-Western Journal of Zoology, 10(1), 74-82. Retrieved from: www.scopus.com

Jabłońska, A. \& Pešić, V. 2011. Five aquatic Oligochaeta species new for the fauna of Montenegro. Turkish Journal of Zoology, 35(1), 119-121. doi: 10.3906/z00-0903-12

Jabłońska, A. \& Pešić, V. 2014. Five species of aquatic oligochaetes new to Iran with an updated checklist. Oceanological and Hydrobiological Studies, 43(1), 100-105. doi: 10.2478/s13545-014-0121-3

Jabłońska, A., Szlauer-ŁUkaszewska, A. \& Bańkowska, A. 2015. Aulodrilus pigueti Kowalewski, 1914 (Annelida: Clitellata) - A new record for the polish fauna from the oder river and remarks on other oligochaetes rarely noticed in Poland. Oceanological and Hydrobiological Studies, 44(4), 456-465. doi: 10.1515/0hs-2015-0043

Jamieson, B.G.M. 1988. On the phylogeny and higher classification of the Oligochaeta. Cladistics, 4(4), 367-401. doi: 10.1111/j.1096-0031.1988. tb00520.x

Jamieson, B.G.M., Erseus, C. \& Ferraguti, M. 1987. Parsimony analysis of the phylogeny of some Oligochaeta (Annelida) using spermatozoal ultrastructure. Cladistics, 3(2), 145-155. doi: 10.1111/j.1096-0031.1987. tb00503.x

Jenderedjian, K. 1996. Energy budget of Oligochaeta and its relationship with the primary production of Lake Sevan, Armenia. Hydrobiologia, 334(1-3), 133-140. doi: 10.1007/BF00017362

Jiang, T., Du, S., Sun, P. \& Zhu, M. 2012. Effect of oligochaete worm body fluids on biological phosphorus removal in a bench-scale EBPR system. 
Environmental Technology (United Kingdom), 33(15), 1755-1762. doi: 10.1080/09593330.2011.644866

Johnson, P. \& Ladle, M. 1989. The Enchytraeidae (Oligochaeta) of streams of southern England. [Les Enchytraeidae (Oligochaeta) des eaux courantes du sud de I'Angleterre]. Annales de Limnologie, 25(2), 121-129. doi: 10.1051/limn/1989012

Juget, J. 1987. Contribution to the study of the rhyacodrilinae (Tubificidae, Oligochaeta), with description of two new stygobiont species from the alluvial plain of the french upper rhone, Rhyacodrilus amphigenus, sp. nov., and Rhizodriloides phreaticola, gen. nov., sp. nov. Hydrobiologia, 155(1), 107-118. doi: 10.1007/BF00025635

Juget, J., Goubier, V. \& Barthélémy, D. 1989. Intrinsic and extrinsic variables controlling the productivity of asexual populations of Nais sp., (Naididae, Oligochaeta). Hydrobiologia, 180(1), 177-184. doi: 10.1007/ BF00027550

Juget, J. \& Lafont, M. 1994. Distribution of Oligochaeta in some lakes and pools of Bolivia. Hydrobiologia, 278(1-3), 125-127. doi: 10.1007/BF00142319

Juget, J. \& Lafont, M. 1994. Theoretical habitat templets, species traits, and species richness: Aquatic oligochaetes in the upper rhône river and its floodplain. Freshwater Biology, 31(3), 327-340. doi: 10.1111/j.13652427.1994.tb01744.x

Juget, J., Riera, P. \& Schmelz, R. 1994. A study of the trophic relationship between biotecton and Naididae (Nais sp., Oligochaeta): Importance of organic carbon. [Etude des relations trophiques entre le biotecton et les Naididae (Nais sp., Oligochaeta): Importance du carbone organique (C.0.T.)]. Annales de Limnologie, 30(4), 253-265. doi: 10.1051/ $\underline{\text { limn } / 1994019}$

Juget, J. \& Yacoubi-Khebiza, M. 1997. Research on the ecology of Astacopsidrilus naceri giani and martin, 1995 (Phreodrilidae, Oligochaeta) from the groundwaters of Morocco. [Contribution a l'ecologie de l'espece Astacopsidrilus naceri Giani and Martin, 1995 (Phreodrilidae, Oligochaeta) en provenance des eaux souterraines du Maroc]. Annales de Limnologie, 33(3), 149-161. Retrieved from: www. scopus.com

Kaeser, A.J. \& Sharpe, W.E. 2006. Patterns of distribution and abundance of Tubifex tubifex and other aquatic oligochaetes in Myxobolus cerebralis enzootic areas in pennsylvania. Journal of Aquatic Animal Health, 18(1), 64-78. doi: $10.1577 /$ H05-016.1

Kahl, K. \& Golanska, M. 1987. Diversity and numbers of Oligochaeta against the background of other macroinvertebrates in a concrete bed of the River Widawka (central Poland). Acta Hydrobiologica, 29(1), 35-51. Retrieved from: www.scopus.com

Kaǐgorodova, I.A. \& Shcherbakov, D.I. 2006. Molecular phylogenetic study of the systematic position of Baikalian oligochaetes in the system Clitellata. Genetika, 42(12), 1647-1655. Retrieved from: www.scopus.com

Kairesalo, T. \& Koskimies, I. 1987. Grazing by oligochaetes and snails on epiphytes. Freshwater Biology, 17(2), 317-324. doi: 10.1111/j.13652427.1987.tb01051.x

Kaliszewicz, A. 2015. Conspecific alarm cues induce an alternative reproductive strategy in aquatic oligochaetes. Limnology, 16(2), 85-90. doi: 10.1007/s10201-014-0442-3

Kaliszewicz, A., Johst, K., Grimm, V. \& Uchmański, J. 2005. Predation effects on the evolution of life-history traits in a clonal oligochaete. American Naturalist, 166(3), 409-417. doi: 10.1086/432037

Kaliszewicz, A. \& Uchmański, J. 2009. A cross-phyla response to daphnia chemical alarm substances by an aquatic oligochaete. Ecological Research, 24(2), 461-466. doi: 10.1007/s11284-008-0522-0

Kaliszewicz, A. \& Uchmański, J. 2009. Damage released prey alarm substances or predator odours? Risk assessment by an aquatic oligochaete. Hydrobiologia, 618(1), 57-64. doi: 10.1007/s10750-008-9547-1
Karlckhoff, S.W. \& Morris, K.R. 1985. Impact of tubificid oligochaetes on pollutant transport in bottom sediments. Environmental Science \& Technology, 19(1), 51-56. doi: 10.1021/es00131a004

Kaster, J.L. 1989. Observations of predator-prey interaction on dispersal of an oligochaete prey, Limnodrilus hoffmeisteri. Hydrobiologia, 180(1), 191-193. doi: $10.1007 /$ BF00027552

Kathman, R.D.\&Wetzel, M.J. 2003. Allonais inaequalis (Annelida: Oligochaeta: Tubificidae) in North America. Proceedings of the Biological Society of Washington, 116(3), 548-556. Retrieved from: www.scopus.com

Kaviraj, A., Bhunia, F. \& Saha, N.C. 2004. Toxicity of methanol to fish, crustacean, oligochaete worm, and aquatic ecosystem. International Journal of Toxicology, 23(1), 55-63. doi: 10.1080/10915810490265469

Kaygorodova, I.A. \& Sherbakov, D.Y. 2006. Molecular phylogenetic study of the systematic position of Baikalian oligochaetes in Clitellata. Russian Journal of Genetics, 42(12), 1390-1397. doi: 10.1134/S1022795406120052

Kaygorodova, I.A., Verdonschot, P.F.M. \& Kravtsova, L.S. 2012. Freshwater oligochaetes (Oligochaeta, Clitellata, Annelida) of north pribaikalye (east Siberia, Russia). Turkish Journal of Zoology, 36(1), 47-58. doi: 10.3906/z00-1003-140

Kazanci, N. \& Girgin, S. 1998. Distribution of Oligochaeta species as bioindicators of organic pollution in Ankara stream and their use in biomonitoring. Turkish Journal of Zoology, 22(1), 83-87. Retrieved from: www.scopus.com

Keilty, T.J. \& Landrum, P.F. 1990. Population-specific toxicity responses by the freshwater oligochaete, Stylodrilus heringianus, in natural Lake Michigan sediments. Environmental Toxicology and Chemistry, 9(9), 1147-1154. doi: 10.1002/etc.5620090905

Keilty, T.J., White, D.S. \& Landrum, P.F. 1988. Short-term lethality and sediment avoidance assays with endrin-contaminated sediment and two oligochaetes from Lake Michigan. Archives of Environmental Contamination and Toxicology, 17(1), 95-101. doi: 10.1007/BF01055159

Kerovec, M. \& Kerovec, M. 2014. Oligochaeta and polychaeta fauna of the croatian part of the Sava River. [Fauna Oligochaeta i Polychaeta hrvatskog dijela rijeke Save]. Natura Croatica, 23(2), 335-348. Retrieved from: www.scopus.com

Ketelaars, H.A.M., Kuijpers, A.M.J.P. \& Van Breemen, L.W.C.A. 1992. Temporal and spatial distribution of chironomid larvae and oligochaetes in two dutch storage reservoirs. Netherlands Journal of Aquatic Ecology, 26(2-4), 361-369. doi: $10.1007 /$ BF02255263

Kharin, A.V., Zagaǐnova, I.V. \& Kostiuchenko, R.P. 2006. Formation of the zone of paratomy in freshwater oligochaetes. Ontogenez, 37(6), 424-437. Retrieved from: www.scopus.com

Kharin, A.V., Zagainova, I.V. \& Kostyuchenko, R.P. 2006. Formation of the paratomic fission zone in freshwater oligochaetes. Russian Journal of Developmental Biology, 37(6),354-365.doi:10.1134/\$1062360406060038

Kiliç, V., Altunsoy, F. \& Kiliç, G.A. 2011. Effect of thallium on the survival and morphology of Tubifex tubifex (Oligochaeta, Tubificidae). Fresenius Environmental Bulletin, 20(9 A), 2442-2445. Retrieved from: www. scopus.com

Kitakoshi, T. \& Shimizu, T. 2010. An oligochaete homologue of the brachyury gene is expressed transiently in the third quartette of micromeres. Gene Expression Patterns, 10(6), 306-313. doi: 10.1016/j.gep.2010.07.001

Klerks, P.L. \& Bartholomew, P.R. 1991. Cadmium accumulation and detoxification in a cd-resistant population of the oligochaete Limnodrilus hoffmeisteri. Aquatic Toxicology, 19(2), 97-112. doi: 10.1016/0166-445X(91)90030-D

Klump, J.V., Krezoski, J.R., Smith, M. \& Kaster, J.L. 1987. Dual tracer studies of the assimilation of an organic contaminant from sediments by deposit feeding oligochaetes. Canadian Journal of Fisheries and Aquatic Sciences, 44(9), 1574-1583. doi: $10.1139 /$ f87-190 
Koprivnikar, J. \& Desser, S.S. 2002. A new form of raabeia-type actinosporean (Myx0zoa) from the oligochaete Uncinais uncinata. Folia Parasitologica, 49(2), 89-92. doi: $10.14411 / f p .2002 .017$

Kowalski, D.A. \& Bergersen, E.P. 2003. The toxicity of bayluscide and TFM to Tubifex tubifex: Implications for chemical control of the oligochaete host of Myxobolus cerebralis, the causative agent of whirling disease. North American Journal of Aquaculture, 65(3), 171-178. doi: 10.1577/C02-036

Krezoski, J.R. \& Robbins, J.A. 1985. Vertical distribution of feeding and particle-selective transport of 137Cs in lake sediments by Lumbriculid oligochaetes. Journal of Geophysical Research, 90(C6), 11,999-"12,006". Retrieved from: www.scopus.com

Krodkiewska, M. 2006. Freshwater Oligochaeta in mining subsidence ponds in the upper Silesia region of southern Poland. Journal of Freshwater Ecology, 21(1), 177-179. doi: 10.1080/02705060.2006.9664111

Krodkiewska, M. 2007. The distribution of Potamothrix bavaricus (Oeschmann, 1913) (Oligochaeta) in anthropogenic freshwater habitats of an industrialised area (upper Silesia, Poland). Limnologica, 37(3), 259-263. doi: 10.1016/j.limno.2007.02.001

Krodkiewska, M. 2005. The Oligochaeta communities in the benthos of artificially heated Rybnik dam reservoir (Poland). Journal of Freshwater Ecology, 20(1), 117-122. doi: 10.1080/02705060.2005.9664944

Krodkiewska, M. \& Kostecki, M. 2015. Assessment of the restoration measures in a Man-Made Reservoir: Do oligochaete communities respond to the improvement of water quality? Environmental Monitoring and Assessment, 187(9) doi: 10.1007/s10661-015-4787-9

Krodkiewska, M. \& Królczyk, A. 2011. Impact of environmental conditions on bottom oligochaete communities in subsidence ponds (the Silesian upland, southern Poland). International Review of Hydrobiology, 96(1), 48-57. doi: 10.1002/iroh.201011284

Krodkiewska, M. \& Michalik-Kucharz, A. 2009. The bottom Oligochaeta communities in sand pits of different trophic status in upper Silesia (southern Poland). Aquatic Ecology, 43(2), 437-444. doi: 10.1007/ s10452-008-9199-2

Krodkiewska, M. \& Spyra, A. 2015. New data on the biology and habitat preferences of the oligochaete species ripistes parasita (Annelida: (litellata: Naididae): A case study in a temporary woodland pond. Biologia (Poland), 70(5), 615-624. doi: 10.1515/biolog-2015-0070

Kukkonen, J. \& Landrum, P.F. 1994. Toxicokinetics and toxicity of sediment-associated pyrene to Lumbriculus variegatus (Oligochaeta). Environmental Toxicology and Chemistry, 13(9), 1457-1468. doi:10.1002/ etc.5620130909

Lafont, M., Durbec, A. \& Ille, C. 1992. Oligochaete worms as biological describers of the interactions between surface and groundwaters: A first synthesis. Regulated Rivers: Research \& Management, 7(1), 65-73. doi: 10.1002/rrr.3450070109

Lafont, M., Juget, J. \& Rofes, G. 1991. An environmental index based on lacustrine oligochaetes. [Un indice biologique lacustre base sur l'examen des oligochetes]. Revue des Sciences de l'Eau, 4(2), 253-268. Retrieved from: www.scopus.com

Lafont, M. \& Vivier, A. 2006. Oligochaete assemblages in the hyporheic zone and coarse surface sediments: Their importance for understanding of ecological functioning of watercourses. Hydrobiologia, 564 (1 spec. iss.), 171-181. doi: 10.1007/s10750-005-1717-9

Lafont, M., Vivier, A., Nogueira, S., Namour, P. \& Breil, P. 2006. Surface and hyporheic oligochaete assemblages in a french suburban stream. Hydrobiologia, 564 (1 spec. iss.), 183-193. doi: 10.1007/s10750-0051718-8

Lagauzère, S., Pischedda, L., Cuny, P., Gilbert, F., Stora, G. \& Bonzom, J.-2009. Influence of Chironomus riparius (Diptera, Chironomidae) and Tubifex tubifex (Annelida, Oligochaeta) on oxygen uptake by sediments.
Consequences of uranium contamination. Environmental Pollution, 157(4), 1234-1242. doi: 10.1016/j.envpol.2008.12.004

Lang, C. 2001. Anomalous response of zoobenthos (0ligochaetes and Chironomids) to the decrease of phosphorus in Lake Neuchâtel. [Réponse anormale du zoobenthos (Oligochètes et Chironoinides) à la baisse $\mathrm{du}$ phosphore dans le lac de Neuchâtel]. Revue Suisse de Zoologie, 108(4), 891-903. doi: $10.5962 /$ bhl.part.80167

Lang, C. 1999. Contrasting responses of oligochaetes (Annelida) and chironomids (Diptera) to the abatement of eutrophication in Lake Neuchatel. Aquatic Sciences, 61(3), 206-214. doi: 10.1007/PL00001324

Lang, C. 2010. Ecological state of sediment in two mountain lakes indicated by Oligochaetes and Chironomids. [Etat écologique des sédiments de deux lacs de montagne indiqué par les oligochètes et les chironomides]. Bulletin de la Societe Vaudoise des Sciences Naturelles, 92(2), 47-60. Retrieved from: www.scopus.com

Lang, C. 1985. Eutrophication of Lake Geneva indicated by the oligochaete communities of the profundal. Hydrobiologia, 126(3), 237-243. doi: 10.1007/BF00007501

Lang, C. 1989. Eutrophication of Lake Neuchâtel indicated by the oligochaete communities. Hydrobiologia, 174(1), 57-65. doi: 10.1007/BF00006058

Lang, C. 2007. How to interpret changes of zoobenthos (Oligochaetes and (hironomids) in Lake Neuchâtel between 1984 and 2002? [Comment interpréter les modifications du zoobenthos (Oligochètes et Chironomides) dans le lac de Neuchâtel entre 1984 et 2002?]. Bulletin de la Societe Vaudoise des Sciences Naturelles, 90(3), 133-149. Retrieved from: www.scopus.com

Lang, C. 2009. Indices based on Oligochaetes and Chironomids indicating the ecological recovery of sediments in Lake Geneva (Léman). [Indices basés sur les oligochètes et les chironomides indiquant la restauration écologique des sédiments du Léman]. Bulletin de la Societe Vaudoise des Sciences Naturelles, 91(3), 283-300. Retrieved from: www.scopus.com

Lang, C. 1997. Oligochaetes, organic sedimentation, and trophic state: How to assess the biological recovery of sediments in lakes? Aquatic Sciences, 59(1), 26-33. doi: 10.1007/BF02522547

LANG, C. 1990. Quantitative relationships between oligochaete communities and phosphorus concentrations in lakes. Freshwater Biology, 24(2), 327-334. doi: 10.1111/j.1365-2427.1990.tb00713.x

Lang, C. 2000. Response of oligochaete (Tubificidae and Lumbriculidae) and diptera Chironomidae communities to the decrease of phosphorus concentrations in Lake Geneva (little lake). [Reponse des communautes d'oligochetes (Tubificides et Lumbriculides) et de dipteres Chironomides a la baisse des teneurs en phosphore dans le Leman (Petit Lac)]. Annales de Limnologie, 36(1), 13-20. doi: 10.1051/limn/2000001

Lang, C. 1998. Using oligochaetes to monitor the decrease of eutrophication: The 1982-1996 trend in Lake Geneva. Archiv Fur Hydrobiologie, 141(4), 447-458. Retrieved from: www.scopus.com

Lang, C. \& Lods-Crozet, B. 1997. Oligochaetes versus chironomids as indicators of trophic state in two swiss lakes recovering from eutrophication. Archiv Fur Hydrobiologie, 139(2), 187-195. Retrieved from: www.scopus.com

Lang, C. \& Reymond, 0. 1995. Contrasting responses of oligochaete communities to the abatement of eutrophication in Lake Geneva. Hydrobiologia, 308(1), 77-82. doi: 10.1007/BF00037789

Lang, C. \& Reymond, 0. 1995. Empirical relationships between oligochaete communities and phosphorus in lakes before and after the abatement of eutrophication. Archiv Fur Hydrobiologie, 134(4), 491-497. Retrieved from: www.scopus.com

Lang, C. \& Reymond, 0. 1996. Empirical relationships between oligochaetes, phosphorus and organic deposition during the recovery of Lake Geneva from eutrophication. Archiv Fur Hydrobiologie, 136(2), 237-245. Retrieved from: www.scopus.com 
Lang, C. \& Reymond, 0. 1995. Recovery from eutrophication delayed in the profundal of Lake Neuchatel: Evidence from the oligochaete communities. Revue Suisse de Zoologie, 102(4), 907-912. Retrieved from: www.scopus.com

Lang, C. \& Reymond, 0. 1992. Reversal of eutrophication in Lake Geneva: Evidence from the oligochaete communities. Freshwater Biology, 28(2), 145-148. doi: 10.1111/j.1365-2427.1992.tb00571.x

Lanzavecchia, G., Valvassori, R. \& de Eguileor, M. 1994. Body wall muscles in oligochaetes. Hydrobiologia, 278(1-3), 179-188. doi:10.1007/BF00142326

Larsson, J. 1989. Light and electron microscope studies on Jirovecia involuta sp. nov. (Microspora, Bacillidiidae), a new microsporidian parasite of oligochaetes in Sweden. European Journal of Protistology, 25(2), 172-181. doi: 10.1016/S0932-4739(89)80028-8

Lasier, P.J. 2009. Alternative substrates for culturing the freshwater oligochaete Lumbriculus variegatus. North American Journal of Aquaculture, 71(1), 87-92. doi: $10.1577 / A 07-104.1$

Lauritsen, D.D., Mozley, S.C. \& White, D.S. 1985. Distribution of oligochaetes in Lake Michigan and comments on their use as indices of pollution. Journal of Great Lakes Research, 11(1), 67-76. doi: 10.1016/503801330(85)71745-5

Lazim, M.N. \& Learner, M.A. 1987. The influence of sediment composition and leaf litter on the distribution of Tubificid worms (Oligochaeta) - A field and laboratory study. Oecologia, 72(1), 131-136. doi: 10.1007/ $\underline{B F 00385057}$

Lazim, M.N. \& Learner, M.A. 1986. The life-cycle and productivity of Tubifex tubifex (Oligochaeta; Tibificidae) in the Moat-Feeder stream, Cardiff, south wales. Ecography, 9(3), 185-192. doi: 10.1111/j.1600-0587.1986. tb01208.x

Lazim, M.N., Learner, M.A. \& Cooper, S. 1989. The importance of worm identity and life history in determining the vertical distribution of Tubificids (Oligochaeta) in a riverine mud. Hydrobiologia, 178(1), 81-92. doi: $10.1007 / B F 00006115$

Leppänen, M.T. \& Kukkonen, J.V.K. 1998. Factors affecting feeding rate, reproduction and growth of an oligochaete Lumbriculus variegatus (Müller). Hydrobiologia, 377(1-3), 183-194. Retrieved from: www. scopus.com

Leppänen, M.T. \& Kukkonen, J.V.K. 1998. Relative importance of ingested sediment and pore water as bioaccumulation routes for pyrene to oligochaete (Lumbriculus variegatus, Müller). Environmental Science \& Technology, 32(10), 1503-1508. doi: 10.1021/es970941k

Leppänen, M.T. \& Kukkonen, J.V.K. 2004. Toxicokinetics of sedimentassociated polybrominated diphenylethers (Flame retardants) in benthic invertebrates (Lumbriculus variegatus, Oligochaeta). Environmental Toxicology and Chemistry, 23(1), 166-172. doi: 10.1897/03-68

Lesiuk, N.M. \& Drewes, C.D. 1999. Autotomy reflex in a freshwater oligochaete, Lumbriculus variegatus (Clitellata: Lumbriculidae). Hydrobiologia, 406, 253-261. doi: $10.1023 / \mathrm{A}: 1003756722019$

Lesiuk, N.M. \& Drewes, C.D. 2001. Behavioral plasticity and central regeneration of locomotor reflexes in the freshwater oligochaete, Lumbriculus variegatus. II. Ablation studies. Invertebrate Biology, 120(3), 259-268. doi: 10.1111/j.1744-7410.2001.tb00036.x

Liebig, M., Egeler, P., Oehlmann, J. \& Knacker, T. 2005. Bioaccumulation of 14C-17a-ethinylestradiol by the aquatic oligochaete Lumbriculus variegatus in spiked artificial sediment. Chemosphere, 59(2), 271-280. doi: $10.1016 /$ j.chemosphere.2004.10.051

Lietz, D.M. 1987. Potential for aquatic oligochaetes as live food in commercial aquaculture. Hydrobiologia, 155(1), 309-310. doi: 10.1007/BF00025665

Lin, K.-. \& Yo, S.-. 2008. The effect of organic pollution on the abundance and distribution of aquatic oligochaetes in an urban water basin, Taiwan. Hydrobiologia, 596(1), 213-223. doi: 10.1007/s10750-007-9098-x
Lindegaard, C., Hamburger, K. \& Dall, P.C. 1994. Population dynamics and energy budget of Marionina southerni (Cernosvitov) (Enchytraeidae, Oligochaeta) in the shallow littoral of Lake Esrom, Denmark. Hydrobiologia, 278(1-3), 291-301. doi: 10.1007/BF00142338

Linhares Frizzera, G. \& da Gama Alves, R. 2012. The influence of taxonomic resolution of Oligochaeta on the evaluation of water quality in an urban stream in Minas Gerais, Brazil. [A influência da resolução taxonômica de Oligochaeta na avaliação da qualidade da água em um córrego urbano em Minas Gerais, Brasil]. Acta Limnologica Brasiliensia, 24(4), 408-416. doi: 10.1590/S2179975X2013005000005

Lobo, H. \& Alves, R.G. 2011. Influence of body weight and substrate granulometry on the reproduction of Limnodrilus hoffmeisteri (Oligochaeta: Naididae: Tubificinae). Zoologia, 28(5), 558-564. doi: 10.1590/S1984-46702011000500002

Lobo, H. \& da Gama Alves, R. 2011. Reproductive cycle of Branchiura sowerbyi (Oligochaeta: Naididae: Tubificinae) cultivated under laboratory conditions. Zoologia, 28(4), 427-431. doi: $\underline{10.1590 / 51984-}$ 46702011000400003

Lods-Crozet, B. \& Reymond, 0. 2005. Ten years trends in the oligochaete and chironomid fauna of Lake Neuchâtel (Switzerland). Revue Suisse de Zoologie, 112(2), 543-558. doi: 10.5962/bhl.part.80313

Löhlein, B. 1999. Assessment of secondary production of Naididae (Oligochaeta): An example from a north german lake. Hydrobiologia, 406, 191-198. doi: 10.1023/A:1003736217476

Löhlein, B. \& Böttger, K. 1996. The Oligochaeta (Annelida) of a near-natural lowland stream in northern Germany. [Die Oligochaeta (Annelida) eines naturnahen baches im Norddeutschen tiefland]. Limnologica, 26(4), 393-402. Retrieved from: www.scopus.com

López Van Oosterom, M.V., Ocon, C., Armendariz, L.C. \& Rodrigues Capítulo, A. 2015. Structural and functional responses of the oligochaete and aeolosomatid assemblage in lowland streams: A one-way-pollutionmodelled ecosystem. Journal of Limnology, 74(3) doi: 10.4081/ jlimnol.2015.1142

Lotufo, G.R. \& Fleeger, J.W. 1996. Toxicity of sediment-associated pyrene and phenanthrene to Limnodrilus hoffmeisteri (Oligochaeta: Tubificidae). Environmental Toxicology and Chemistry, 15(9), 1508-1516. Retrieved from: www.scopus.com

Lowers, J.M. \& Bartholomew, J.L. 2003. Detection of myxozoan parasites in oligochaetes imported as food for ornamental fish. Journal of Parasitology, 89(1),84-91. doi:10.1645/0022-3395(2003)089[0084:DOMPI0]2.0.C0;2

Lu, X., Reible, D.D., Fleeger, J.W. \& Chai, Y. 2003. Bioavailability of desorptionresistant phenanthrene to the oligochaete llyodrilus templetoni. Environmental Toxicology and Chemistry, 22(1), 153-160. Retrieved from: www.scopus.com

Lucan-Bouché, M.-., Arsac, F., Biagianti-Risbourg, S., Habets, F. \& Vernet, G. 1997. Experimental study of the lethal effects induced by copper and lead on the Oligochaeta Tubifex tubifex. [Étude expérimentale des effets létaux induits par le cuivre et/ou le plomb chez l'0ligochète Tubifex tubifex]. Bulletin de la Societe Zoologique de France, 122(4), 389-392. Retrieved from: www.scopus.com

Lucan-Bouché, M.-., Biagianti-Risbourg, S., Arsac, F. \& Vernet, G. 1999. An original decontamination process developed by the aquatic oligochaete Tubifex tubifex exposed to copper and lead. Aquatic Toxicology, 45(1), 9-17. doi: $10.1016 / 50166-445 X(98) 00091-5$

Lucan-Bouché, M.-., Biagianti-Risbourg, S., Arsac, F. \& Vernet, G. 1999. Autotomy as a mechanism of decontamination used by the oligochaete Tubifex tubifex. [L'autotomie comme moyen de décontamination utilisé par l'oligochète Tubifex tubifex]. Bulletin de la Societe Zoologique de France, 124(4), 383-387. Retrieved from: www.scopus.com 
Lyytikäinen, M., Rantalainen, A.--., Mikkelson, P., Hämäläinen, H., Paasivirta, J. \& Kukkonen, J.V.K. 2003. Similarities in bioaccumulation patterns of polychlorinated dibenzo-p-dioxins and furans and polychlorinated diphenyl ethers in laboratory-exposed oligochaetes and semipermeable membrane devices and in field-collected chironomids. Environmental Toxicology and Chemistry, 22(10), 2405-2415. doi: 10.1897/02-433

MacKie, J.A., Levinton, J.S., Przeslawski, R., Delambert, D. \& Wallace, W. 2010. Loss of evolutionary resistance by the oligochaete Limnodrilus hoffmeisteri to a toxic substance - cost or gene flow? Evolution, 64(1), 152-165. doi: 10.1111/j.1558-5646.2009.00806.x

Macmichael, G.J., Brown, L.R. \& Ladner, C.M. 1988. An oligochaete as a potential food source for fish in aquaculture. Progressive Fish-Culturist, 50(1), 31-35. doi:10.1577/1548-8640(1988)050[0031:AOAAPF]2.3.C0;2

Mäenpää, K. \& Kukkonen, J.V.K. 2006. Bioaccumulation and toxicity of 4-nonylphenol (4-NP) and 4-(2-dodecyl)-benzene sulfonate (LAS) in Lumbriculus variegatus (Oligochaeta) and Chironomus riparius (Insecta). Aquatic Toxicology, 77(3), 329-338. doi: 10.1016/j.aquatox.2006.01.002

Mäenpää, K., Leppänen, M.T. \& Kukkonen, J.V.K. 2009. Sublethal toxicity and biotransformation of pyrene in Lumbriculus variegatus (Oligochaeta). Science of the Total Environment, 407(8), 2666-2672. doi: 10.1016/j. scitotenv.2009.01.019

Mäenpää, K., Sorsa, K., Lyytikäinen, M., Leppänen, M.T. \& Kukkonen, J.V.K. 2008. Bioaccumulation, sublethal toxicity, and biotransformation of sediment-associated pentachlorophenol in Lumbriculus variegatus (Oligochaeta). Ecotoxicology and Environmental Safety, 69(1), 121-129. doi: 10.1016/j.ecoenv.2006.12.019

Mäenpää, K.A., Sormunen, A.J. \& Kukkonen, J.V.K. 2003. Bioaccumulation and toxicity of sediment associated herbicides (ioxynil, pendimethalin, and bentazone) in Lumbriculus variegatus (Oligochaeta) and Chironomus riparius (Insecta). Ecotoxicology and Environmental Safety, 56(3), 398-410. doi: 10.1016/S0147-6513(03)00010-1

Maestre, Z., Martinez-Madrid, M., Rodriguez, P. \& Reynoldson, T. 2007. Ecotoxicity assessment of river sediments and a critical evaluation of some of the procedures used in the aquatic oligochaete Tubifex tubifex chronic bioassay. Archives of Environmental Contamination and Toxicology, 53(4), 559-570. doi: 10.1007/s00244-006-0264-3

Manum, S.B., Bose, M.N. \& Sawyer, R.T. 1991. Clitellate cocoons in freshwater deposits since the triassic. Zoologica Scripta, 20(4), 347-366. doi: 10.1111/j.1463-6409.1991.tb00300.x

Marchese, M. 1994. Population dynamics of Narapa bonettoi righi and varela, 1983 (Oligochaeta: Narapidae) from the main channel of the middle Paraná River, Argentina. Hydrobiologia, 278(1-3), 303-308. doi:10.1007/ BF00142339

Marchese, M.R. 1987. The ecology of some benthic Oligochaeta from the Paraná River, Argentina. Hydrobiologia, 155(1), 209-214. doi: 10.1007/ BF00025653

Marotta, R., Ferraguti, M., Erséus, C. \& Gustavsson, L.M. 2008. Combined-data phylogenetics and character evolution of Clitellata (Annelida) using 185 rDNA and morphology. Zoological Journal of the Linnean Society, 154(1), 1-26. doi: 10.1111/j.1096-3642.2008.00408.x

Martin, P. \& Brinkhurst, R.0. 1998. A new genus and two new species of Tubificidae (Oligochaeta) from the abyssal zone of Lake Baikal with redescriptions of Lymphachaeta pinnigera, Rhyacodriloides abyssalis and Tubifex bazikalovae. Zoologica Scripta, 27(3), 197-207. doi:10.1111/ j.1463-6409.1998.tb00437.x

Martin, P. \& Brinkhurst, R.0. 1994. A new species of Insulodrilus (Oligochaeta, Phreodrilidae) from Lake Tanganyika (East Africa) with notes on the oligochaete fauna of the lake. Archiv Fur Hydrobiologie, 130(2), 249-256. Retrieved from: www.scopus.com
Martin, P., Ferraguti, M. \& Kaygorodova, I. 1998. Description of two new species of Rhynchelmis (Oligochaeta: Lumbriculidae) from Lake Baikal (Russia), using classical morphology and ultrastructure of spermatozoa. Annales de Limnologie, 34(3), 283-293. doi: 10.1051/ limn/1998025

Martin, P.\& Giani,N. 1995. Insulodrilus martensi, a new species of Phreodrilidae (Oligochaeta) from Lake Tanganyika (East Africa). [Insulodrilus martensi, une nouvelle espèce de Phreodrilidae (Oligochaeta) du lac Tanganyika (Afrique de l'Est)]. Annales de Limnologie, 31(1), 3-8. doi: 10.1051/ $\operatorname{limn} / 1995003$

Martin, P. \& Giani, N. 1995. Two new species of epirodrilus (Oligochaeta, Tubificidae) from Lake Nyasa and Tanganyika (East Africa), with redescriptions of E. slovenicus and E. michaelseni. Zoologica Scripta, 24(1), 13-19. doi: 10.1111/j.1463-6409.1995.tb00471.x

Martin, P., Goddeeris, B. \& Martens, K. 1994. Depth distribution of oligochaetes in Lake Baikal (Siberia, Russia). Hydrobiologia, 278(1-3), 151-156. doi: 10.1007/BF00142323

Martin, P., Kaygorodova, I., Sherbakov, D.Y. \& Verheyen, E. 2000. Rapidly evolving lineages impede the resolution of phylogenetic relationships among Clitellata (Annelida). Molecular Phylogenetics and Evolution, 15(3), 355-368. doi: 10.1006/mpev.1999.0764

Martin, P., Martens, K. \& Goddeeris, B. 1999. Oligochaeta from the abyssal zone of Lake Baikal (Siberia, Russia). Hydrobiologia, 406, 165-174. doi: 10.1023/A:1003719430680

Martin, P., Martinez-Ansemil, E., Pinder, A., Timm, T. \& Wetzel, M.J. 2008. Global diversity of Oligochaetous clitellates ("Oligochaeta"; Clitellata) in freshwater. Hydrobiologia, 595(1), 117-127. doi: 10.1007/s10750-0079009-1

Martin, P., Schmelz, R.M. \& Dole-Olivier, M.-. 2015. Groundwater oligochaetes (Annelida, Clitellata) from the Mercantour National Park (France), with the descriptions of one new genus and two new stygobiont species. Zoosystema, 37(4), 551-569. doi: 10.5252/z2015n4a2

Martínez, D.E. \& Levinton, J. 1996. Adaptation to heavy metals in the aquatic oligochaete Limnodrilus hoffmeisteri: Evidence for control by one gene. Evolution, 50(3), 1339-1343. Retrieved from: www.scopus.com

Martinez-Ansemil, E. 1990. Biological and ecological study of the aquatic oligochaetes of the River Tambre and its environment (Galicia, Spain). [Etude biologique et écologique des Oligochètes aquatiquesde la rivière Tambre et de ses milieux associés (Galice, Espagne)]. Annales de Limnologie, 26(2), 131-151. doi: 10.1051/limn/1990013

Martínez-Ansemil, E. \& Collado, R. 1996. Two new species of freshwater Oligochaeta from the north-west Iberian Peninsula: Krenedrilus realis sp. nov. (Tubificidae) and (ernosvitoviella bulboducta sp. nov. (Enchytraeidae). Journal of Zoology, 240(2), 363-370. doi: 10.1111/ j.1469-7998.1996.tb05291.x

Martínez-Ansemil, E., Creuzé Des Châtelliers, M., Martin, P. \& Sambugar, B. 2012. The Parvidrilidae - a diversified groundwater family: Description of six new species from southern europe, and clues for its phylogenetic position within Clitellata (Annelida). Zoological Journal of the Linnean Society, 166(3), 530-558. doi: 10.1111/j.1096-3642.2012.00857.x

Martinez-Ansemil, E. \& Giani, N. 1987. The distribution of aquatic oligochaetes in the south and eastern mediterranean area. Hydrobiologia, 155(1), 293-303. doi: $10.1007 / B F 00025662$

Martínez-Ansemil, E., Giani, N. \& Sambugar, B. 2002. Oligochaetes from underground waters of oman with descriptions of two new species of Phreodrilidae (Oligochaeta): Antarctodrilus arabicus sp. nov., and Phreodrilus stocki sp. nov. Contributions to Zoology, 71(4), 147-158. Retrieved from: www.scopus.com

Martínez-Ansemil, E., Sambugar, B. \& Giani, N. 2002. First record of Parvidrilidae (Annelida, Oligochaeta) in europe with a description of a 
new species (Parvidrilus spelaeus sp. nov.) and comments on the family and its phyletic relationships. Journal of Zoology, 256(4), 495-503. Retrieved from: www.scopus.com

Martínez-Ansemil, E., Sambugar, B. \& Giani, N. 1997. Groundwater oligochaetes from southern-europe. I. A new genus and three new species of rhyacodrilinae (Tubificidae) with a redescription of Tubifex pescei (Dumnicka) comb. nov. Annales de Limnologie, 33(1), 33-44. doi: 10.1051/limn/1997003

Martinez-Tabche, L., Ortega, M.D.L.A.G., Ramirez Mora, B., German Faz, C., Lopez Lopez, E. \& Galar Martinez, M. 2001. Hemoglobin concentration and acetylcholinesterase activity of oligochaetes in relation to lead concentration in spiked sediments from Ignacio Ramirez Reservoir. Ecotoxicology and Environmental Safety, 49(1), 76-83. doi: 10.1006/ eesa.2001.2030

Martinovic-Vitanovic, V., Djikanovic, V., Obradovic, S. \& Kalafatic, V. 2007. Composition and structure of the Oligochaeta (Annelida) in benthic assemblages of the Danube River in the Belgrade region during may and october of 2004. Ekologia Bratislava, 26(2), 174-189. Retrieved from: www.scopus.com

Martins, R.T. \& Alves, R.G. 2010. Occurrence of Chaetogaster limnaei K. von Baer, 1927 (Oligochaeta, Naididae) associated with Gastropoda mollusks in horticultural channels in southeastern Brazil. [0corrência de Chaetogaster limnaei K. von Baer, 1927 (Oligochaeta, Naididae) associado com moluscos Gastropoda em canais de horticultura no sudeste do Brasil]. Brazilian Journal of Biology, 70(4), 1055-1057. doi: $10.1590 /$ S1519-69842010000500020

Martins, R.T. \& Da Gama Alves, R. 2008. Occurrence of Naididae (Annelida: Oligochaeta) from three gastropod species in irrigation fields in southeastern Brazil. Biota Neotropica, 8(3), 255-257. doi: 10.1590/ $\underline{\text { S1676-06032008000300023 }}$

Martins, R.T., Silveira, L.S. \& Alves, R.G. 2011. Colonization by oligochaetes (Annelida: Clitellata) in decomposing leaves of Eichhornia azurea (SW.) Kunth (Pontederiaceae) in a neotropical lentic system. Annales de Limnologie, 47(4), 339-346. doi: 10.1051/limn/2011053

Mastrantuono, L. 1988. A note on the feeding of Amphichaeta leydigii (Oligochaeta, Naididae) in lacustrine sandy shores. Hydrobiological Bulletin, 22(2), 195-198. doi: 10.1007/BF02256823

Mathooko, J.M., Mpawenayo, B., Kipkemboi, J.K. \& M'erimba, C.M. 2005. Distributional patterns of diatoms and Limnodrilus oligochaetes in a kenyan dry streambed following the 1999-2000 drought conditions. International Review of Hydrobiology, 90(2), 185-200. doi: 10.1002/ iroh.200310708

Matisoff, G., Wang, X. \& McCall, P.L. 1999. Biological redistribution of lake sediments by tubificid oligochaetes: Branchiura sowerbyi and Limnodrilus hoffmeisteri/Tubifex tubifex. Journal of Great Lakes Research, 25(1), 205-219. doi: 10.1016/50380-1330(99)70729-X

Matsuo, K. \& Shimizu, T. 2006. Embryonic expression of a decapentaplegic gene in the oligochaete annelid Tubifex tubifex. Gene Expression Patterns, 6(8), 800-806. doi: 10.1016/j.modgep.2006.01.009

Matsuo, K., Yoshida, H. \& Shimizu, T. 2005. Differential expression of caudal and dorsal genes in the teloblast lineages of the oligochaete annelid Tubifex tubifex. Development Genes and Evolution, 215(5), 238-247. doi: 10.1007/s00427-005-0473-1

Measures, L.N. 1988. The development of Eustrongylides tubifex (Nematoda: Dioctophymatoidea) in oligochaetes. Journal of Parasitology, 74(2), 294-304. doi: 10.2307/3282459

Méndez-Fernández, L., De Jonge, M. \& Bervoets, L. 2014. Influences of sediment geochemistry on metal accumulation rates and toxicity in the aquatic oligochaete Tubifex tubifex. Aquatic Toxicology, 157, 109-119. doi: 10.1016/j.aquatox.2014.10.009
Méndez-Fernández, L., Martínez-Madrid, M.\& Rodriguez, P. 2013. Toxicity and critical body residues of $C D, C U$ and $C R$ in the aquatic oligochaete Tubifex tubifex (Müller) based on lethal and sublethal effects. Ecotoxicology, 22(10), 1445-1460. doi: $10.1007 /$ s 10646-013-1131-4

Merle, C., Danielopol, D.L. \& Watanamahart, P. 1997. Impact of environmental conditions on the habitat selection of interstitial-dwelling Tubificids (Oligochaeta). An experimental study. Geobios, 30 (suppl. 2), 91-99. doi: 10.1016/50016-6995(97)80074-5

Mermillod-Blondin, F., Creuze des Chatelliers, M., Gerino, M. \& Gaudet, J.2000. Testing the effect of Limnodrilus sp. (Oligochaeta, Tubificidae) on organic matter and nutrient processing in the hyporheic zone: $\mathrm{A}$ microcosm method. Archiv Fur Hydrobiologie, 149(3), 467-487. Retrieved from: www.scopus.com

Mermillod-Blondin, F., Gérino, M., Degrange, V., Lensi, R., Chassé, J.-., Rard, M. \& Creuzé des Châtelliers, M. 2001. Testing the functional redundancy of Limnodrilus and Tubifex (Oligochaeta, Tubificidae) in hyporheic sediments: An experimental study in microcosms. Canadian Journal of Fisheries and Aquatic Sciences, 58(9), 1747-1759. doi: 10.1139/f01-119

Mermillod-Blondin, F., Poggiale, J.-., Tolla, C., Auger, P., Thuiller, W. \& Des Châtelliers, M.C. 2008. Using a mathematical model to simulate the influence of Tubificid worms (Oligochaeta) on oxygen concentrations in hyporheic sediments. Fundamental and Applied Limnology, 172(2), 135-145. doi: 10.1127/1863-9135/2008/0172-0135

Meyer, J.S., Boese, C.J. \& Collyard, S.A. 2002. Whole-body accumulation of copper predicts acute toxicity to an aquatic oligochaete (Lumbriculus variegatus) as $\mathrm{pH}$ and calcium are varied. Comparative Biochemistry and Physiology - Part C: Toxicology and Pharmacology, 133(1-2), 99-109. doi: 10.1016/S1532-0456(02)00103-5

Mihaljević, Z., Kerovec, M., Ternjej, I. \& Mrakovcić, M. 2001. Composition and depth distribution of oligochaete fauna in a mediterranean karstic lake. Biologia, 56(5), 461-467. Retrieved from: www.scopus.com

Milbrink, G. 1993. Evidence for mutualistic interactions in freshwater oligochaete communities. Oikos, 68(2), 317-322. doi: 10.2307/3544845

Milbrink, G. 1994. Oligochaetes and water pollution in two deep norwegian lakes. Hydrobiologia, 278(1-3), 213-222. doi: 10.1007/BF00142329

Milbrink, G., Timm, T. \& Lundberg, S. 2002. Indicative profundal oligochaete assemblages in selected small swedish lakes. Hydrobiologia, 468, 53-61. doi: 10.1023/A:1015274323026

Millward, R.N., Fleeger, J.W., Reible, D.D., Keteles, K.A., Cunningham, B.P. \& Zhang, L. 2001. Pyrene bioaccumulation, effects of pyrene exposure on particle-size selection, and fecal pyrene content in the oligochaete Limnodrilus hoffmeisteri (Tubificidae, Oligochaeta). Environmental Toxicology and Chemistry, 20(6), 1359-1366. doi: 10.1002/ etc.5620200627

Mischke, C.C. \& Griffin, M.J. 2011. Laboratory mass culture of the freshwater oligochaete Dero digitata. North American Journal of Aquaculture, 73(1), 13-16. doi: $10.1080 / 15222055.2011 .544936$

Mischke, C.C., Terhune,J.S.\&Wise, D.J.2001. Acute toxicity of several chemicals to the oligochaete Dero digitata. Journal of the World Aquaculture Society, 32(2), 184-188. doi: 10.1111/j.1749-7345.2001.tb01093.x

Molnár, K., El-Mansy, A., Székely, C. \& Baska, F. 1999. Development of Myxobolus dispar (Myxosporea: Myxobolidae) in an oligochaete alternate host, Tubifex tubifex. Folia Parasitologica, 46(1), 15-21. Retrieved from: www.scopus.com

Molnár, L. \& Fischer, E. 1989. The effect of saline load on the elemental composition of chloragosomes in Limnodrilus hoffmeisteri (Oligochaeta, Tubificidae). Comparative Biochemistry and Physiology - Part A: Physiology, 92(4), 551-553. doi: 10.1016/0300-9629(89)90364-2

Montalto, L. \& Marchese, M. 2005. Cyst formation in Tubificidae (Naidinae) and opistocystidae (Annelida, Oligochaeta) as an adaptive strategy for 
drought tolerance in fluvial wetlands of the Paraná River, Argentina. Wetlands, 25(2), 488-494. doi: 10.1672/23

Montanholi-Martins, M.C. \& Takeda, A.M. 1999. Communities of benthic oligochaetes in relation to sediment structure in the upper Parana River, Brazil. Studies on Neotropical Fauna and Environment, 34(1), 52-58. Retrieved from: www.scopus.com

Montanholi-Martins, M.C. \& Takeda, A.M. 2001. Spatial and temporal variations of oligochaetes of the Ivinhema River and Patos Lake in the upper Paraná River basin, Brazil. Hydrobiologia, 463, 197-205. doi: 10.1023/A:1013163927814

Moretto, Y., Simões, N.R., Benedito, E. \& Higuti, J. 2013. Effect of trophic status and sediment particle size on diversity and abundance of aquatic Oligochaeta (Annelida) in neotropical reservoirs. Annales de Limnologie, 49(1), 65-78. doi: 10.1051/limn/2013040

Morev, Y.B. \& Smailova, T.S. 1987. Food assimilation rate of Tubificid worms Tubifex tubifex (Oligochaeta). Hydrobiological Journal, 23(2), 69-72. Retrieved from: www.scopus.com

Mosleh, Y.Y., Paris-Palacios, S., Arnoult, F., Couderchet, M., Biagianti-Risbourg, S. \& Vernet, G. 2004. Metallothionein induction in aquatic oligochaete Tubifex tubifex exposed to herbicide isoproturon. Environmental Toxicology, 19(1), 88-93. doi: 10.1002/tox.10153

Mosleh, Y.Y., Paris-Palacios, S., Arnoult, F., Couderchet, M. \& Vernet, G. 2003. Metallothionein induction in the aquatic oligochaete Tubifex tubifex exposed to the herbicide isoproturon. Communications in Agricultural and Applied Biological Sciences, 68(4 Pt B), 759-770. Retrieved from: www. scopus.com

Mosleh, Y.Y., Paris-Palacios, S. \& Biagianti-Risbourg, S. 2006. Metallothioneins induction and antioxidative response in aquatic worms Tubifex tubifex (Oligochaeta, Tubificidae) exposed to copper. Chemosphere, 64(1), 121-128. doi: 10.1016/j.chemosphere.2005.10.045

Mosleh, Y.Y., Paris-Palacios, S., Couderchet, M., Biagianti-Risbourg, S. \& Vernet, G. 2005. Metallothionein induction, antioxidative responses, glycogen and growth changes in Tubifex tubifex (Oligochaete) exposed to the fungicide, fenhexamid. Environmental Pollution, 135(1), 73-82. doi: 10.1016/j.envpol.2004.10.012

Mount, D.R., Highland, T.L., Mattson, V.R., Dawson, T.D., Lott, K.G. \& Ingersoll, C.G. 2006. Use of the oligochaete, Lumbriculus variegatus, as a prey organism for toxicant exposure of fish through the diet. Environmental Toxicology and Chemistry, 25(10), 2760-2767. doi: 10.1897/06-138.1

Müller, M.C.M. 2004. Nerve development, growth and differentiation during regeneration in Enchytraeus fragmentosus and Stylaria lacustris (Oligochaeta). Development Growth \& Differentiation, 46(5), 471-478. doi: 10.1111/j.1440-169x.2004.00763.x

Naitoh, T. \& Matsuno, A. 1985. Demonstration of the structural connections of the longitudinal muscle cells and circular muscle cells, and interconnections between the two, in the alimentary canal of an oligochaete, Branchiura sowerbyi Beddard. Experientia, 41(3), 370-372. doi: 10.1007/BF02004510

Nascimento, H.L.S. \& Alves, R.D.G. 2008. Cocoon production and hatching rates of Branchiura sowerbyi Beddard (Oligochaeta: Tubificidae). Revista Brasileira de Zoologia, 25(1), 16-19. doi: 10.1590/5010181752008000100003

Nascimento, H.L.S. \& Alves, R.G. 2009. The effect of temperature on the reproduction of Limnodrilus hoffmeisteri (Oligochaeta: Tubificidae). Zoologia, 26(1), 191-193. doi: 10.1590/S1984-46702009000100026

Nasi, M., Piol, M.N., Di Risio, C. \& Verrengia Guerrero, N.R. 2011. Investigating arsenic bioavailability and bioaccumulation by the freshwater oligochaete Lumbriculus variegatus. Archives of Environmental Contamination and Toxicology, 61(3), 426-434. doi: 10.1007/s00244-010-9639-6
Naveed, M.I. 2012. Preliminary studies on aquatic Oligochaeta in and around Chennai, Tamil Nadu, India. Turkish Journal of Zoology, 36(1), 25-37. doi: 10.3906/z00-1002-33

Nazarhaghighi, F., Timm, T., Nadoushan, R.M., Shabanipour, N., Fatemi, M.R. \& Moradi, A.M. 2014. Oligochaetes (Annelida, Clitellata) in the Anzali International Wetland, north-western Iran. Estonian Journal of Ecology, 63(3), 130-144. doi: 10.3176/ec0.2014.3.02

Negredo, C. \& Mulcahy, M.F. 2001. Actinosporean infections in oligochaetes in a river system in southwest Ireland with descriptions of three new forms. Diseases of Aquatic Organisms, 46(1), 67-77. doi: 10.3354/da0046067

Newrkla, P. \& Mutayoba, S. 1987. Why and where do oligochaetes hide their cocoons? Hydrobiologia, 155(1), 171-178. doi: 10.1007/BF00025646

Newrkla, P. \& Wijegoonawardana, N. 1987. Vertical distribution and abundance of benthic invertebrates in profundal sediments of mondsee, with special reference to oligochaetes. Hydrobiologia, 155(1), 227-234. doi: $10.1007 / \mathrm{BF} 00025655$

Nie, X.-., Huang, T.-., Zhang, J.-., Li, W., Li, X.-., Zhang, S. \& Wang, B.-. 2010. Study on inactivation effect and toxic mechanism of chlorine for the aquatic worm Tubifex tubifex (Oligochaeta, Tubificidae). Sustainable Environment Research, 20(5), 341-346. Retrieved from: www.scopus. com

Nijboer, R.C., Wetzel, M.J. \& Verdonschot, P.F.M. 2004. Diversity and distribution of Tubificidae, Naididae, and Lumbriculidae (Annelida: Oligochaeta) in the netherlands: An evaluation of twenty years of monitoring data. Hydrobiologia, 520(1-3), 127-141. doi: 10.1023/B:HYDR.0000027732.88238.61

Nikkilä, A., Halme, A. \& Kukkonen, J.V.K. 2003. Toxicokinetics, toxicity and lethal body residues of two chlorophenols in the oligochaete worm, Lumbriculus variegatus, in different sediments. Chemosphere, 51(1), 35-46. doi: 10.1016/50045-6535(02)00791-9

Nikkilä, A., Kukkonen, J.V.K. \& Oikari, A. 2001. Bioavailability of sedimentassociated retene to an oligochaete worm Lumbriculus variegates: Effects of sediment organic carbon and retene concentration. Journal of Soils and Sediments, 1(3), 137-145. doi: 10.1007/BF02986476

Nishino, M., Ohtaka, A. \& Narita, T. 1999. Studies on the aquatic oligochaete fauna in Lake Biwa, central Japan. III. Distribution of respective taxa within the lake. Japanese Journal of Limnology (Rikusuigaku Zasshi), 60(4), 539-558. doi: 10.3739/rikusui.60.539

Nuutinen, S. \& Kukkonen, J.V.K. 1998. The effect of selenium and organic material in lake sediments on the bioaccumulation of methylmercury by Lumbriculus variegatus (Oligochaeta). Biogeochemistry, 40(2-3), 267-278. Retrieved from: www.scopus.com

Nylander, J.A.A., Erséus, C. \& Källersjö, M. 1999. A test of monophyly of the gutless Phallodrilinae (Oligochaeta, Tubificidae) and the use of a 573-bp region of the mitochondrial cytochrome oxidase I gene in analysis of annelid phylogeny. Zoologica Scripta, 28(3-4), 305-313. doi: 10.1046/j.1463-6409.1999.00001.x

Oda, F.H., Petsch, D.K., Ragonha, F.H., Batista, V.G., Takeda, A.M. \& Takemoto, R.M. 2015. Dero (Allodero) Lutzi michaelsen, 1926 (Oligochaeta: Naididae) associated with Scinax fuscovarius (Lutz, 1925) (Anura: Hylidae) from semi-deciduous atlantic rain forest, southern Brazil. [Dero (Allodero) Lutzi Michaelsen, 1926 (Oligochaeta: Naididae) associado com Scinax fuscovarius (Lutz, 1925) (Anura: Hylidae) na Floresta Estacional Semidecidual, Sul do Brasil]. Brazilian Journal of Biology, 75(1), 86-90. doi: $10.1590 / 1519-6984.07613$

Odabaşı, S., Odabaşı, D.A. \& Arslan, N. 2015. The first record of Chaetogaster limnaei limnaei Baer 1827 (Annelida: Clitellata) on Pseudobithynia yildirimi (Gastropoda: Prosobranchia) from northwest of Turkey. Turkish Journal of Fisheries and Aquatic Sciences, 15(2), 367-369. doi: 10.4194/1303-2712-v15 219 
O'Gara, B.A., Bohannon, V.K., Teague, M.W. \& Smeaton, M.B. 2004. Copperinduced changes in locomotor behaviors and neuronal physiology of the freshwater oligochaete, Lumbriculus variegatus. Aquatic Toxicology, 69(1), 51-66. doi: 10.1016/j.aquatox.2004.04.006

Ohtaka, A. 2004. A new species of the subterranean genus Krenedrilus Dumnicka (Oligochaeta, Tubificidae) from the deep bottom of an oligotrophic Caldera Lake in Japan. Zoological Science, 21(4), 465-471. doi: $10.2108 / 25 j .21 .465$

Ohtaka, A. \& Ichiyanagi, H. 2015. Water environment and species composition of profundal oligochaetes in dam lakes of Japan. Ecology and Civil Engineering, 18(2), 87-98. doi: 10.3825/ece. 18.87

Ohtaka, A. \& Iwakuma, T. 1993. Redescription of ophidonais serpentina (Muller, 1773) (Naididae, Oligochaeta) from Lake Yunoko, central Japan, with record of the oligochaete composition in the lake. Japanese Journal of Limnology (Rikusuigaku Zasshi), 54(4), 251-259. doi: 10.3739/ rikusui.54.251

Ohtaka, A. \& Martin, P. 2011. Redescriptions of Spirosperma apapillatus and Embolocephalus nikolskyi (Annelida, Clitellata, Tubificinae) from Japan, with reference to distribution of Papillate tubificines in japanese freshwaters. Zoological Science, 28(5), 368-379. doi: 10.2108/zsj.28.368

Ohtaka, A. \& Morino, H. 1986. Seasonal changes in the epiphytic animals on the Potamogeton malaianus in Lake Kita-Ura, with special reference to oligochaetes. Japanese Journal of Limnology (Rikusuigaku Zasshi), 47(1), 63-75. doi: $10.3739 /$ rikusui.47.63

Ohtaka, A. \& Nishino, M. 2012. Diversity and distribution of aquatic oligochaetes (Annelida, Clitellata) in Lake Biwa. Lake Biwa: Interactions between nature and people. (pp. 79-83) doi: 10.1007/978-94-007-17831 2. Retrieved from: www.scopus.com

Ohtaka, A. \& Nishino, M. 1995. Studies on the aquatic oligochaete fauna in Lake Biwa, central Japan. I. Checklist with taxonomic remarks. Japanese Journal of Limnology (Rikusuigaku Zasshi), 56(3), 167-182. doi: 10.3739/ rikusui.56.167

Ohtaka, A. \& Nishino, M. 1999. Studies on the aquatic oligochaete fauna in Lake Biwa, central Japan. II. Records and taxonomic remarks of nine species. Hydrobiologia, 406, 33-47. doi: 10.1023/A:1003795311154

Ohtaka, A. \& Nishino, M. 2006. Studies on the aquatic oligochaete fauna in Lake Biwa, Central Japan. IV. Faunal characteristics in the attached lakes (Naiko). Limnology, 7(2), 129-142. doi: 10.1007/s10201-006-0173-1

Oliver, B.G. 1987. Biouptake of chlorinated hydrocarbons from laboratoryspiked and field sediments by oligochaete worms. Environmental Science \& Technology, 21(8), 785-790. doi: 10.1021/es00162a009

Omodeo, P. 1987. Some new species of Haplotaxidae (Oligochaeta) from guinea and remarks on the history of the family. Hydrobiologia, 155(1), 1-13. doi: $10.1007 / B F 00025626$

Oyama, A. \& Shimizu, T. 2007. Transient occurrence of vasa-expressing cells in nongenital segments during embryonic development in the oligochaete annelid Tubifex tubifex. Development Genes and Evolution, 217(10), 675-690. doi: 10.1007/s00427-007-0180-1

Oyama, A., Yoshida, H. \& Shimizu, T. 2008. Embryonic expression of p68, a DEAD-box RNA helicase, in the oligochaete annelid Tubifex tubifex. Gene Expression Patterns, 8(6), 464-470. doi: 10.1016/j.gep.2008.02.003

Özer, A. \& Wootten, R. 2001. Ultrastructural observations on the development of some actinosporean types within their oligochaete hosts. Turkish Journal of Zoology, 25(3), 199-216. Retrieved from: www.scopus.com

Pasteris, A., Vecchi, M. \& Bonomi, G. 1999. A comparison among different population models for Limnodrilus hoffmeisteri claparede (Oligochaeta, Tubificidae). Hydrobiologia, 406, 183-189. doi: 10.1023/A:1003748520202

Pasteris, A., Vecchi, M., Reynoldson, T.B. \& Bonomi, G. 2003. Toxicity of copper-spiked sediments to Tubifex tubifex (Oligochaeta, Tubificidae): A comparison of the 28-day reproductive bioassay with a 6-month cohort experiment. Aquatic Toxicology, 65(3), 253-265. doi: 10.1016/50166445X(03)00136-X

Pathiratne, A. \& Weerasundara, A. 2004. Bioassessment of selected inland water bodies in sri lanka using benthic oligochaetes with consideration of temporal variations. International Review of Hydrobiology, 89(3), 305-316. doi: 10.1002/iroh.200310676

Paumen, M.L., Stol, P., Laak, T.L.T., Kraak, M.H.S., Van Gestel, C.A.M. \& Admiraal, W. 2008. Chronic exposure of the oligochaete Lumbriculus variegatus to polycyclic aromatic compounds (PACs): Bioavailability and effects on reproduction. Environmental Science \& Technology, 42(9), 3434-3440. doi: 10.1021/es702500t

Paunovic, M., Kalafatic, V., Jakovcev, D. \& Martinovic-Vitanovic, V. 2003. Oligochaetes (Annelida, Oligochaeta) of the Vlasina River (south-east Serbia): Diversity and distribution. Biologia - Section Zoology, 58(5), 903-911. Retrieved from: www.scopus.com

Pelegri, S.P. \& Blackburn, T.H. 1995. Effects of Tubifex tubifex (Oligochaeta: Tubificidae) on $\mathrm{N}$-mineralization in freshwater sediments, measured with 15N isotopes. Aquatic Microbial Ecology, 9(3), 289-294. doi: 10.3354/ame009289

Penttinen, 0.-., Kilpi-Koski, J., Jokela, M., Toivainen, K. \& Väisänen, A. 2008. Importance of dose metrics for lethal and sublethal sediment metal toxicity in the oligochaete worm Lumbriculus variegatus. Journal of Soils and Sediments, 8(1), 59-66. doi: 10.1065/jss2007.12.267

Peralta, L., Escobar, E., Alcocer, J. \& Lugo, A. 2002. Oligochaetes from six tropical crater lakes in Central Mexico: Species composition, density and biomass. Hydrobiologia, 467, 109-116. doi: 10.1023/A:1014913503577

Petersen, S., Arlt, G., Faubel, A. \& Carman, K.R. 1998. On the nutritive significance of dissolved free amino acid uptake for the cosmopolitan oligochaete Nais elinguis Müller (Naididae). Estuarine, Coastal and Shelf Science, 46(1), 85-91. doi: 10.1006/ecss.1997.0253

Petsch, D.K., Ragonha, F.H., Gimenez, B.C.G., Barboza, L.G.A. \& Takeda, A.M. 2015. Partitioning beta diversity of aquatic Oligochaeta in different environments of a neotropical floodplain. [Partição da diversidade beta de Oligochaeta aquático em diferentes ambientes de uma planície de inundação neotropical]. Acta Scientiarum - Biological Sciences, 37(1), 41-49. doi: $10.4025 /$ actascibiolsci.v37i1.21738

Phipps, G.L., Ankley, G.T., Benoit, D.A. \& Mattson, V.R. 1993. Use of the aquatic oligochaete Lumbriculus variegatus for assessing the toxicity and bioaccumulation of sediment-associated contaminants. Environmental Toxicology and Chemistry, 12(2), 269-279. doi: 10.1002/etc.5620120210

Pinder, A.M. 2003. First australian records of three species and two genera of aquatic oligochaetes (Clitellata: Annelida). Proceedings of the Linnean Society of New South Wales, 124, 109-114. Retrieved from: www.scopus.com

Pinder, A.M. \& Brinkhurst, R.0. 1997. First records of slavina (0ligochaeta: Naididae) in Australia and description of a new species. Proceedings of the Royal Society of Victoria, 109(2), 149-155. Retrieved from: www. scopus.com

Pinder, A.M. \& Brinkhurst, R.0. 1997. Review of the Phreodrilidae (Annelida: Oligochaeta: Tubificida) of Australia. Invertebrate Taxonomy, 11(3), 443-523. Retrieved from: www.scopus.com

Pinder, A.M. \& Brinkhurst, R.0. 1997. The family capilloventridae (Annelida, (litellata) in Australia, with descriptions of two new species of capilloventer. Zoologica Scripta, 26(3), 255-265. doi: 10.1111/j.14636409.1997.tb00415.x

Polatdemir Arslan, N. \& Şahin, Y. 2003. Nine new Naididae (Oligochaeta) species for Sakarya River, Turkey. Turkish Journal of Zoology, 27(1), 27-38. Retrieved from: www.scopus.com

Prenda, J. \& Gallardo, A. 1992. The influence of environmental factors and microhabitat availability on the distribution of an aquatic oligochaete 
assemblage in a Mediterranean River basin. Internationale Revue Der Gesamten Hydrobiologie Und Hydrographie, 77(3), 421-434. doi:10.1002/ iroh. 19920770306

Probst, L. 1987. Sublittoral and profundal Oligochaeta fauna of the Lake Constance (Bodensee-Obersee). Hydrobiologia, 155(1), 277-282. doi: $10.1007 / B F 00025660$

Pujals,M.A. 1988. Especies del género Dero Oken, 1815 (Oligochaeta, Naididae) en la provincia de Buenos Aires, Argentina. Studies on Neotropical Fauna and Environment, 23(4), 203-212. doi: 10.1080/01650528809360764

Purschke, G. 1999. Terrestrial polychaetes - models for the evolution of the Clitellata (Annelida)? Hydrobiologia, 406, 87-99. doi: 10.1023/A:1003780032497

Putzer, V., Gnaiger, E. \& Lackner, R. 1985. Flexibility of anaerobic metabolism in aquatic oligochaetes (Tubifex sp.). Biochemical and calorimetric changes induced by a deproteinized hydrolysate of bovine blood. Comparative Biochemistry and Physiology - Part A: Physiology, 82(4), 965-970. doi: 10.1016/0300-9629(85)90513-4

Putzer, V.M., de Zwaan, A. \& Wieser, W. 1990. Anaerobic energy metabolism in the oligochaete Lumbriculus variegatus Müller. Journal of Comparative Physiology B, 159(6), 707-715. doi: 10.1007/BF00691716

Qi, S. 1987. Some ecological aspects of aquatic oligochaetes in the lower Pearl River (people's Republic of China). Hydrobiologia, 155(1), 199-208. doi: 10.1007/BF00025652

Rácz, 0.Z., Eszterbauer, E. \& Molnár, K. 2005. Hungactinomyxon, a new actinosporean type and collective group (Myxozoa) from Branchiura sowerbyi Beddard (Oligochaeta). Systematic Parasitology, 61(2), 107-113. doi: 10.1007/s11230-005-3136-8

Ragonha, F.H., Chiaramonte, J.B., Junior, H.M.F., da Cunha, E.R., Benedito, E. \& Takeda, A.M. 2013. Spatial distribution of aquatic Oligochaeta in Ilha Grande National Park, Brazil. [Distribuição espacial de Oligochaeta aquático no Parque Nacional de Ilha Grande, Brasil]. Acta Scientiarum - Biological Sciences, 35(1), 63-70. doi: 10.4025/actascibiolsci. v35i1.10768

Ragonha, F.H., Petsch, D.K., Alves, G.H.Z., Santana, H.S., Michelan, T.S. \& Takeda, A.M. 2014. Tributaries as richness source for Oligochaeta assemblage (Annelida) of Neotropical dammed river. [Tributários como fontes de riqueza para assembleia de Oligochaeta (Annelida) de um rio Neotropical represado]. Brazilian Journal of Biology, 74(4), 861-869. doi: 10.1590/1519-6984.05613

Ragonha, F.H. \& Takeda, A.M. 2014. Does richness of Oligochaeta (Annelida) follows a linear distribution with habitat structural heterogeneity in aquatic sediments? Journal of Limnology, 73(1), 146-156. doi: 10.4081/ jimnol.2014.791

Ramskov, T., Thit, A., Croteau, M.-. \& Selck, H. 2015. Biodynamics of copper oxide nanoparticles and copper ions in an oligochaete - Part I: Relative importance of water and sediment as exposure routes. Aquatic Toxicology, 164, 81-91. doi: $10.1016 /$ j.aquatox.2015.04.022

Raposeiro, P.M., Ramos, J.C. \& Costa, A.C. 2009. First record of Branchiura sowerbyi Beddard, 1892 (Oligochaeta: Tubificidae) in azores. Aquatic Invasions, 4(3), 487-490. doi: 10.3391/ai.2009.4.3.8

Ratsak, C.H., Koouman, S.A.L.M. \& Kooi, B.W. 1993. Modelling the growth of an oligochaete on activated sludge. Water Research, 27(5), 739-747. doi: 10.1016/0043-1354(93)90136-6

Ratsak, C.H. \& Verkuijlen, J. 2006. Sludge reduction by predatory activity of aquatic oligochaetes in wastewater treatment plants: Science or fiction? A review. Hydrobiologia, 564 (1 spec. iss.), 197-211. doi: 10.1007/ s10750-005-1719-7

Real, M. \& Prat, N. 1992. Factors influencing the distribution of chironomids and oligochaetes in profundal areas of spanish reservoirs. Netherlands Journal of Aquatic Ecology, 26(2-4), 405-410. doi: 10.1007/BF02255269
Real, M., Sabater, F. \& Morguí, J.A. 1992. Significant physiographic disturbances in the ebro basin reservoirs (N.E. Spain) reflected by Oligochaeta size spectra. Hydrobiologia, 235-236(1), 363-374. doi: 10.1007/BF00026226

Rech, K.C., Guereschi, R.M., de Oliveira Nuñer, A.P. \& Sticca, S.C. 2013. Density and organic matter influence on egg-laying and hatching of Branchiura sowerbyi (Oligochaeta). Journal of the World Aquaculture Society, 44(2), 267-272. doi: 10.1111/jwas.12026

Redeker, E.S., Bervoets, L. \& Blust, R. 2004. Dynamic model for the accumulation of cadmium and zinc from water and sediment by the aquatic oligochaete, Tubifex tubifex. Environmental Science \& Technology, 38(23), 6193-6200. doi: 10.1021/es0496470

Redeker, E.S. \& Blust, R. 2004. Accumulation and toxicity of cadmium in the aquatic oligochaete Tubifex tubifex: A kinetic modeling approach. Environmental Science \& Technology, 38(2), 537-543. doi: 10.1021/ es0343858

Reible, D.D., Popov, V., Valsaraj, K.T., Thibodeaux, L.J., Lin, F., Dikshit, M., ... Fleeger, J.W. 1996. Contaminant fluxes from sediment due to tubificid oligochaete bioturbation. Water Research, 30(3), 704-714. doi: 10.1016/0043-1354(95)00187-5

Reynoldson, T.B. 1994. A field test of a sediment bioassay with the oligochaete worm Tubifex tubifex (Müller, 1774). Hydrobiologia, 278(1-3), 223-230. doi: 10.1007/BF00142330

Reynoldson, T.B. 1987. The role of environmental factors in the ecology of tubificid oligochaetes - an experimental study. Ecography, 10(4), 241-248. doi: 10.1111/j.1600-0587.1987.tb00765.x

Reynoldson, T.B., Thompson, S.P. \& Bamsey, J.L. 1991. A sediment bioassay using the tubificid oligochaete worm Tubifex tubifex. Environmental Toxicology and Chemistry, 10(8), 1061-1072. doi: 10.1002/ etc.5620100811

Rieradevall, M. \& Real, M. 1994. On the distribution patterns and population dynamics of sublittoral and profundal Oligochaeta fauna from Lake Banyoles (Catalonia, NE Spain). Hydrobiologia, 278(1-3), 139-149. doi: 10.1007/BF00142322

Rodrigues, L.F.T., Leite, F.S. \& Alves, R.G. 2013. Inventory and distribution of Oligochaeta (Annelida, Clitellata) in first-order streams in preserved areas of the state of Minas Gerais, Brazil. [Inventário e distribuição de Oligochaeta (Annelida, Clitellata) em córregos de primeira ordem localizados em áreas preservadas do estado de Minas Gerais, Brasil]. Biota Neotropica, 13(1), 245-254. doi: 10.1590/51676-06032013000100024

Rodrigues, L.F.T., Santana, L.D. \& Alves, R.G. 2013. Aquatic oligochaetes associated with bryophytes in an atlantic forest stream. [Oligoquetas aquáticos associados a briófitas em um córrego de Mata Atlântica]. Biota Neotropica, 13(4), 371-375. doi: 10.1590/51676-06032013000400031

Rodriguez, P. 1988. On some species of Lumbriculidae (Annelida: Oligochaeta) from the north of the Iberian Peninsula. [Sur certaines espèces de Lumbriculidae (Annelida: Oligochaeta) du nord de la péninsule ibérique]. Annales de Limnologie, 24(3), 203-211. doi: 10.1051/limn/1988018

Rodriguez, P. 1996. Stylodrilus californianus sp. nov., a new Lumbriculid (Annelida: Oligochaeta) from North America. Hydrobiologia, 333(3), 161-164. doi: $10.1007 /$ BF00013430

Rodriguez, P. 1987. The variability of setae of Pristina longiseta Ehrenberg (Oligochaeta, Naididae). Hydrobiologia, 155(1), 39-44. doi: 10.1007/ BF00025629

Rodriguez, P. \& Achurra, A. 2010. New species of aquatic oligochaetes (Annelida: Clitellata) from groundwaters in karstic areas of northern Spain, with taxonomic remarks on Lophochaeta ignota Štolc, 1886. Zootaxa, (2332), 21-39. Retrieved from: www.scopus.com

Rodriguez, P., Arrate, J., Martinez-Madrid, M., Reynoldson, T.B., Schumacher, V. \& Viguri, J. 2006. Toxicity of santander bay sediments to the euryhaline 
freshwater oligochaete Limnodrilus hoffmeisteri. Hydrobiologia, 564 (1 spec. iss.), 157-169. doi: 10.1109/MAP.2006.1650857

Rodriguez, P. \& Coates, K.A. 1996. A new american Stylodrilus species (Lumbriculidae, Oligochaeta). Canadian Journal of Zoology, 74(1), 92-96. doi: 10.1139/z96-012

Rodriguez, P. \& Fend, S.V. 2013. New species of Rhyacodrilus (Annelida: (litellata: Rhyacodrilinae) of North America, with re-description of R. sodalis (Eisen, 1879). Zootaxa, 3664(1), 1-44. doi: 10.11646/ zootaxa.3664.1.1

Rodriguez, P., Fend, S.V. \& Lenat, D.R. 2014. Sylphella puccoon gen. nov., sp. nov., and two additional new species of aquatic oligochaetes (Lumbriculidae, Clitellata) from poorly-known lotic habitats in north carolina (USA). ZooKeys, (451), 1-32. doi: 10.3897/zookeys.451.7304

Rodriguez, P. \& Giani, N. 1994. A preliminary review of the taxonomic characters used for the systematics of the genus Trichodrilus Claparède (Oligochaeta, Lumbriculidae). Hydrobiologia, 278(1-3), 35-51. doi: 10.1007/BF00142310

Rodriguez, P. \& Giani, N. 1989. New species of Phallodrilus (Oligochaeta, Tubificidae) from caves of northern Spain and southwestern France. Hydrobiologia, 180(1), 57-63. doi: 10.1007/BF00027537

Rodriguez, P. \& Rico, E. 2008. A new freshwater oligochaete species (Clitellata: Enchytraeidae) from Livingston Island, Antarctica. Polar Biology, 31(10), 1267-1279. doi: 10.1007/s00300-008-0465-5

Rosa, B.F.J.V., Martins, R.T. \& Alves, R.G. 2015. Distribution of oligochaetes in a stream in the atlantic forest in southeastern Brazil. [Distribuição de oligoquetas em um riacho da mata atlântica, sudeste do Brasil]. Brazilian Journal of Biology, 75(1), 1-7. doi: 10.1590/1519-6984.02313

Rosa, B.J.F.V., Rodrigues, L.F.T., de Oliveira, G.S. \& da Gama Alves, R. 2014. Chironomidae and Oligochaeta for water quality evaluation in an urban river in southeastern Brazil. Environmental Monitoring and Assessment, 186(11), 7771-7779. doi: 10.1007/s10661-014-3965-5

Rosso, A., Lafont, M. \& Exinger, A. 1993. Effects of heavy metals on oligochaete communities of the river ill and its tributaries (Haut-Rhin, France). [Effets des métaux lourds sur les peuplements d'oligochètes de l'lll et de ses affluents (Haut-Rhin, France)]. Annales de Limnologie, 29(3), 295-305. doi: $10.1051 /$ limn/1993024

Rota, E. \& Manconi, R. 2004. Taxonomy and ecology of sponge-associate Marionina sp. (Clitellata: Enchytraeidae) from the horomatangi geothermal system of Lake Taupo, New Zealand. International Review of Hydrobiology, 89(1), 58-67. doi: 10.1002/iroh.200310695

Růžičková, S., Schenková, J., Weissová, V. \& Helešic, J. 2014. Environmental impact of heated mining waters on clitellate (Annelida: Clitellata) assemblages. Biologia (Poland), 69(9), 1179-1189. doi: 10.2478/s11756014-0424-2

Sager, M. \& Pucsko, R. 1991. Trace element concentrations of oligochaetes and relations to sediment characteristics in the reservoir at Altenwörth, Austria. Hydrobiologia, 226(1), 39-49. doi: 10.1007/BF00007778

Şahin, S.K. \& Yildiz, S. 2011. Species distribution of oligochaetes related to environmental parameters in Lake Sapanca (Marmara Region, Turkey). [Oligoket türlerinin Sapanca gölü'nde (Marmara Bölgesi, Türkiye) çevresel parametrelerle ilişkili daği\{dotless\}li\{dotless\}mi\{dotless\}]. Turkish Journal of Fisheries and Aquatic Sciences, 11(3), 359-366. doi: 10.4194/1303-2712-v11 304

Sang, Q. \& Erséus, C. 1985. Ecological survey of the aquatic oligochaetes in the lower pearl river (people's Republic of China). Hydrobiologia, 128(1), 39-44. doi: $10.1007 / B F 00008938$

Sardo, A.M. \& Soares, A.M.V.M. 2010. Can behavioural responses of Lumbriculus variegatus (Oligochaeta) assess sediment toxicity? A case study with sediments exposed to acid mine drainage. Environmental Pollution, 158(2), 636-640. doi: 10.1016/j.envpol.2009.08.015
Sardo, A.M. \& Soares, A.M.V.M. 2011. Short- and long-term exposure of Lumbriculus variegatus (Oligochaete) to metal lead: Ecotoxicological and behavioral effects. Human and Ecological Risk Assessment, 17(5), 1108-1123. doi: 10.1080/10807039.2011.605721

Sardo, A.M., Soares, A.M.V.M. \& Gerhardt, A. 2007. Behavior, growth, and reproduction of Lumbriculus variegatus (Oligochaetae) in different sediment types. Human and Ecological Risk Assessment, 13(3), 519-526. doi: $10.1080 / 10807030701341043$

Särkkä, J. 1994. Lacustrine, profundal meiobenthic oligochaetes as indicators of trophy and organic loading. Hydrobiologia, 278(1-3), 231-241. doi: 10.1007/BF00142331

Särkkä, J. 1989. Meiobenthic naidid and aeolosomatid oligochaetes from the profundal zone, and relations of species to eutrophication. Hydrobiologia, 180(1), 185-190. doi: 10.1007/BF00027551

Särkkä, J. 1987. The occurrence of oligochaetes in lake chains receiving pulp mill waste and their relation to eutrophication on the trophic scale. Hydrobiologia, 155(1), 259-266. doi: 10.1007/BF00025658

Schenková, J., Helešic, J. \& Jarkovský, J. 2006. Seasonal dynamics of Bythonomus lemani and Bothrioneurum vejdovskyanum (Oligochaeta, Annelida) in relation to environmental variables. Biologia, 61(5), 517-523. Retrieved from: www.scopus.com

Schenková, J., Komárek, 0. \& Zahrádková, S. 2001. Oligochaeta of the morava and odra river basins (Czech Republic): Species distribution and community composition. Hydrobiologia, 463, 235-240. doi: 10.1023/A:1013128413701

Schenková, J., Paøil, P., Petøivalská, K. \& Bojková, J. 2010. Aquatic oligochaetes (Annelida: Clitellata) of the (zech Republic: Check-list, new records, and ecological remarks. Zootaxa, (2676), 29-44. Retrieved from: www. scopus.com

Schierwater, B. \& Hauenschild, C. 1990. A photoperiod determined lifecycle in an oligochaete worm. Biological Bulletin, 178(2), 111-117. doi: $10.2307 / 1541969$

Schlegel, M., Steinbrück, G., Kramer, M. \& Brockmeyer, V. 1991. Restriction fragment patterns as molecular markers for species identification and phylogenetic analysis in the genus Enchytraeus (Oligochaeta). Journal of Zoological Systematics and Evolutionary Research, 29(5-6), 362-372. doi: 10.1111/j.1439-0469.1991.tb00458.x

Schloesser, D.W., Reynoldson, T.B. \& Manny, B.A. 1995. Oligochaete fauna of western Lake Erie 1961 and 1982: Signs of sediment quality recovery. Journal of Great Lakes Research, 21(3), 294-306. doi: 10.1016/503801330(95)71040-1

Schmelz, R.M. 1994. Oligochaetes of the River Rhine. Preliminary records. Hydrobiologia, 278(1-3), 85-86. doi: 10.1007/BF00142314

Schmelz, R.M., Jocque, M. \& Collado, R. 2015. Microdrile Oligochaeta in bromeliad pools of a honduran cloud forest. Zootaxa, 3947(4), 508-526. doi: 10.11646/zootaxa.3947.4.3

Schmelz, R.M. \& Westheide, W. 2000. Ultrastructure of oesophageal appendages ("peptonephridia") in enchytraeids (Annelida: (litellata). Invertebrate Biology, 119(1), 94-103. Retrieved from: www.scopus.com

Schuytema, G.S., Krawczyk, D.F., Grlffis, W.L., Nebeker, A.V., Robideaux, M.L., Brownawell, B.J. \& Westall, J.C. 1988. Comparative uptake of hexachlorobenzene by fathead minnows, amphipods and oligochaete worms from water and sediment. Environmental Toxicology and Chemistry, 7(12), 1035-1045. doi: 10.1002/etc.5620071211

Sedlmeier, U.A. \& Hoffmann, K.H. 1989. Integumentary uptake of short-chain carboxylic acids by two freshwater oligochaetes, Tubifex tubifex and Lumbriculus variegatus: Specificity of uptake and characterization of transport carrier. Journal of Experimental Zoology, 250(2), 128-134. doi: 10.1002/jez.1402500203 
Shaw, R. 1992. Host tracking and photosensitivity in Chaetogaster limnaei limnaei (0ligochaeta). Canadian Journal of Zoology, 70(3), 578-581. doi: 10.1139/292-086

Sheedy, B.R., Mattson, V.R., Cox, J.S., Kosian, P.A., Phipps, G.L. \& Ankley, G.T. 1998. Bioconcentration of polycyclic aromatic hydrocarbons by the freshwater oligochaete Lumbriculus variegatus. Chemosphere, 36(15), 3061-3070. doi: 10.1016/50045-6535(98)00007-1

Shimizu, T., Nakamoto, A. \& Nakamoto, A. 2014. Developmental significance of $D$ quadrant micromeres $2 \mathrm{~d}$ and $4 \mathrm{~d}$ in the oligochaete annelid Tubifex tubifex. International Journal of Developmental Biology, 58(6-8), 445-456. doi: $10.1387 / \mathrm{ijdb} .140102$ tsh

Shimizu, T. \& Savage, R.M. 2002. Expression of hunchback protein in a subset of ectodermal teloblasts of the oligochaete annelid Tubifex. Development Genes and Evolution, 212(11), 520-525. doi: 10.1007/s00427-002-0278-4

Shirakashi, S. \& El-Matbouli, M. 2009. Myxobolus cerebralis (Myxozoa), the causative agent of whirling disease, reduces fecundity and feeding activity of Tubifex tubifex (Oligochaeta). Parasitology, 136(6), 603-613. doi: $10.1017 / 50031182009005721$

Simpson, I.C., Roger, P.A., Oficial, R. \& Grant, I.F. 1993. Density and composition of aquatic oligochaete populations in different farmers' ricefields. Biology and Fertility of Soils, 16(1), 34-40. doi: 10.1007/BF00336512

Simpson, I.C., Roger, P.A., Oficial, R. \& Grant, I.F. 1993. Impacts of agricultural practices on aquatic oligochaete populations in ricefields. Biology and Fertility of Soils, 16(1), 27-33. doi: $10.1007 /$ BF00336511

Smit, H., van Heel, E.D. \& Wiersma, S. 1993. Biovolume as a tool in biomass determination of Oligochaeta and Chironomidae. Freshwater Biology, 29(1), 37-46. doi: 10.1111/j.1365-2427.1993.tb00742.x

Smith, D.P., Kennedy, J.H. \& Dickson, K.L. 1991. An evaluation of a naidid oligochaete as a toxicity test organism. Environmental Toxicology and Chemistry, 10(11), 1459-1465. doi: 10.1002/etc.5620101111

Smith, M.E. 1986. Ecology of Naididae (Oligochaeta) from an alkaline bog stream: Life history patterns and community structure. Hydrobiologia, 133(1), 79-90. doi: 10.1007/BF00010805

Smith, M.E. 1985. Population and reproductive dynamics of Nais communis (Oligochaeta: Naididae) from a wisconsin limnocrene. American Midland Naturalist, 114(1), 152-158. doi: $10.2307 / 2425250$

Smith, M.E. \& Kaster, J.L. 1986. Feeding habits and dietary overlap of Naididae (0ligochaeta) from a bog stream. Hydrobiologia, 137(3), 193-201. doi: 10.1007/BF00004233

Smythe, A.B., Forgrave, K., Patti, A., Hochberg, R. \& Litvaitis, M.K. 2015. Untangling the ecology, taxonomy, and evolution of Chaetogaster limnaei (Oligochaeta: Naididae) species complex. Journal of Parasitology, 101(3), 320-326. doi: 10.1645/13-465.1

Snimschikova, L.N. \& Akinshina, T.W. 1994. Oligochaete fauna of Lake Baikal. Hydrobiologia, 278(1-3), 27-34. doi: 10.1007/BF00142309

Snimshchikova, L.N. 1998. Revision of the genus lycodrilus grube and description of the evolution of Limnodrilus claparede (Oligochaeta, Tubificidae) species in Lake Baikal. 2. Revision of the species lycodrilus grubei with discussion of the current taxonomic position of Limnodrilus species from Lake Baikal and their evolution. Zoologicheskii Zhurnal, 77(6), 646-XII. Retrieved from: www.scopus.com

Snimshchikova, L.N. \& Akinshina, T.V. 1995. Rhyacodrilus stephensoni (Oligochaeta, Tubificidae) from Lake Baikal. Hydrobiological Journal, 31(4), 70-76. Retrieved from: www.scopus.com

Snitgen, J.L. \& Sibley, P.K. 1998. New record for the oligochaete amphichaeta americana (Oligochaeta: Naididae) in Minnesota. Journal of Freshwater Ecology, 13(3), 369-370. doi: 10.1080/02705060.1998.9663631

Snow, P. \& Buss, L.W. 1994. H0M/Hox-type homeoboxes from Stylaria lacustris (Annelida: Oligochaeta). Molecular Phylogenetics and Evolution, 3(4), 360-364. doi: 10.1006/mpev.1994.1042
Sormunen, A.J., Leppänen, M.T.\& Kukkonen, J.V.K. 2008. Influence of sediment ingestion and exposure concentration on the bioavailable fraction of sediment-associated tetrachlorobiphenyl in oligochaetes. Environmental Toxicology and Chemistry, 27(4), 854-863. doi: 10.1897/07-334.1

Soster, F.M., Harvey, D.T., Troksa, M.R. \& Grooms, T. 1992. The effect of tubificid oligochaetes on the uptake of zinc by Lake Erie sediments. Hydrobiologia, 248(3), 249-258. doi: 10.1007/BF00006151

Soster, F.M. \& McCall, P.L. 1989. Predation by coelotanypus (Diptera: (hironomidae) on laboratory populations of Tubificid oligochaetes. Journal of Great Lakes Research, 15(3), 408-417. doi: 10.1016/503801330(89)71496-9

Spencer, D.R. \& Denton, R.L. 2003. Aquatic Oligochaeta (Annelida: Lumbriculidae, Haplotaxidae, Naididae, Tubificidae) of utah. Western North American Naturalist, 63(3), 343-352. Retrieved from: www.scopus. com

Spencer, D.R. \& Hudson, P.L. 2003. The Oligochaeta (Annelida, Clitellata) of the St. Lawrence great lakes region: An update. Journal of Great Lakes Research, 29(1), 89-104. doi: 10.1016/50380-1330(03)70418-3

Sporka, F. 1996. First record of Aulodrilus pigueti (Oligochaeta, Tubificidae) from the River Morava in Slovakia. Biologia, 51(5), 494. Retrieved from: www.scopus.com

Šporka, F. 1998. The typology of floodplain water bodies of the middle Danube (Slovakia) on the basis of the superficial polychaete and oligochaete fauna. Hydrobiologia, 386(1-3), 55-62. Retrieved from: www.scopus. com

Standley, L.J. 1997. Effect of sedimentary organic matter composition on the partitioning and bioavailability of dieldrin to the oligochaete Lumbriculus variegatus. Environmental Science \& Technology, 31(9), 2577-2583. doi: $10.1021 /$ es 961005 s

Steinbach Elwell, L.C., Kerans, B.L., Rasmussen, C. \& Winton, J.R. 2006. Interactions among two strains of Tubifex tubifex (Oligochaeta: Tubificidae) and Myxobolus cerebralis (Myxozoa). Diseases of Aquatic Organisms, 68(2), 131-139. doi: 10.3354/da0068131

Steinhagen, D. \& Korting, W. 1990. The role of tubificid oligochaetes in the transmission of Goussia carpelli. Journal of Parasitology, 76(1), 104-107. doi: $10.2307 / 3282636$

Steinlechner, R. 1987. Identification of immature Tubificids (Oligochaeta) of Lake Constance and its influence on the evaluation of species distribution. Hydrobiologia, 155(1), 57-63. doi: 10.1007/BF00025631

Stern, M.S., Vinogradov, S.N., Sharma, P.K., Ereifej, K. \& Walz, D.A. 1990. Amino acid sequence of the monomer subunit of the giant extracellular hemoglobin of the aquatic oligochaete, Tubifex tubifex. European Journal of Biochemistry, 194(1), 67-73. doi: 10.1111/j.1432-1033.1990. tb19428.x

Stoll, S., Früh, D., Westerwald, B., Hormel, N. \& Haase, P. 2013. Densitydependent relationship between Chaetogaster limnaei limnaei (Oligochaeta) and the freshwater snail Physa acuta (Pulmonata). Freshwater Science, 32(2), 642-649. doi: 10.1899/12-072.1

Strayer, D. \& Bannon-0'donnell, E. 1988. Aquatic microannelids (Oligochaeta and Aphanoneura) of underground waters of southeastern new york. American Midland Naturalist, 119(2), 327-335. doi: 10.2307/2425815

Strayer, D.L. 2001. Ecology and distribution of hyporheic microannelids (Oligochaeta, Aphanoneura, and Polychaeta) from the eastern united states. Archiv Fur Hydrobiologie, 151(3), 493-510. Retrieved from: www. scopus.com

Struck, T., Hessling, R. \& Purschke, G. 2002. The phylogenetic position of the aeolosomatidae and parergodrilidae, two enigmatic oligochaetelike taxa of the 'polychaeta', based on molecular data from 185 rDNA sequences. Journal of Zoological Systematics and Evolutionary Research, 40(3), 155-163. doi: $10.1046 / \mathrm{j} .1439-0469.2002 .00200 . \mathrm{x}$ 
Sturmbauer, C., Opadiya, G.B., Niederstätter, H., Riedmann, A. \& Dallinger, R. 1999. Mitochondrial DNA reveals cryptic oligochaete species differing in cadmium resistance. Molecular Biology and Evolution, 16(7), 967-974. doi: 10.1093/oxfordjournals.molbev.a026186

Šundic, D., Radujkovic, B.M. \& Krpo-Cetkovic, J. 2011. Catalogue of Naidinae and Pristininae (Annelida: Oligochaeta: Naididae) with twenty species new for Montenegro. Zootaxa, (2737), 1-18. Retrieved from: www. scopus.com

Suriani-Affonso, A.L., França, R.S., Marchese, M. \& Rocha, 0. 2011. Environmental factors and benthic Oligochaeta (Annelida, Clitellata) assemblages in a stretch of the upper São Francisco River (Minas Gerais state, Brazil). [Fatores ambientais e associações de Oligochaeta (Annelida, Clitellata) em um trecho do alto Rio São Francisco (Minas Gerais, Brasil)]. Brazilian Journal of Biology, 71(2), 437-446. Retrieved from: www.scopus.com

Svein-Erik, S.-. 1994. Oligochaete response to changes in water flow in the Dokka Delta, Lake Randsfjorden (Norway), caused by hydroelectric power development. Hydrobiologia, 278(1-3), 243-249. doi: 10.1007/ BF00142332

Svensson, J.M., Enrich-Prast, A. \& Leonardson, L. 2001. Nitrification and denitrification in a eutrophic lake sediment bioturbated by oligochaetes. Aquatic Microbial Ecology, 23(2), 177-186. doi: 10.3354/ame023177

Swayne, H., Day, M. \& Wetzel, M.J. 2004. Limnodrilus hoffmeisteri (Annelida: Oligochaeta: Tubificidae) in pop's cave, wisconsin, USA. Journal of Cave and Karst Studies, 66(1), 28-31. Retrieved from: www.scopus.com

Syrovátka, V., Schenková, J. \& Brabec, K. 2009. The distribution of chironomid larvae and oligochaetes within a stony-bottomed river stretch: The role of substrate and hydraulic characteristics. Fundamental and Applied Limnology, 174(1), 43-62. doi: 10.1127/1863-9135/2009/0174-0043

Szarowska, M. 1987. Annual life cycle of Limnodrilus udekemianus (Oligochaeta, Tubificidae) in the River Biala Przemsza (southern Poland). Acta Hydrobiologica, 29(1), 53-69. Retrieved from: www. scopus.com

Székely, C., Molnár, K., Eszterbauer, E. \& Baska, F. 1999. Experimental detection of the actinospores of Myxobolus pseudodispar (Myxosporea: Myxobolidae) in oligochaete alternate hosts. Diseases of Aquatic Organisms, 38(3), 219-224. doi: 10.3354/da0038219

Székely, C., Rácz, 0., Molnár, K. \& Eszterbauer, E. 2002. Development of Myxobolus macrocapsularis (Myxosporea: Myxobolidae) in an oligochaete alternate host, Tubifex tubifex. Diseases of Aquatic Organisms, 48(2), 117-123. Retrieved from: www.scopus.com

Székely, C., Sitjà-Bobadilla, A. \& Alvarez-Pellitero, P. 2000. First report on the occurrence of an actinosporean stage (Myxozoa) in oligochaetes from spanish freshwaters. Acta Veterinaria Hungarica, 48(4), 433-441. doi: 10.1556/004.48.2000.4.6

Takada, K., Kato, K. \& Okino, T. 1992. Environmental parameters and estivation of Rhyacodrilus (Tubificidae, Oligochaeta) in Lake Suwa, Japan. Ecography, 15(3), 328-333. doi: 10.1111/j.1600-0587.1992.tb00043.x

Takahashi, H., Shimizu, T. \& Aruga, J. 2008. Expression pattern of annelid zic in embryonic development of the oligochaete Tubifex tubifex. Development Genes and Evolution, 218(10), 553-560. doi: 10.1007/s00427-008$\underline{0252-x}$

Takeda, A.M. 1999. Oligochaete community of alluvial upper Paraná River, Brazil: Spatial and temporal distribution (1987-1988). Hydrobiologia, 412, 35-42. doi: 10.1023/A:1003844131148

Taş, M., Kirgiz, T. \& Arslan, N. 2011. Dynamics of Oligochaeta fauna in sazlidere stream (Edirne, Turkey) with relation to environmental factors. Acta Zoologica Bulgarica, 63(2), 179-185. Retrieved from: www.scopus.com

Timm, H. 1994. Production of some oligochaete species in large estonian lakes. Hydrobiologia, 278(1-3), 309-313. doi: 10.1007/BF00142340
Timm, T. 2006. A nearctic tubificid Varichaetadrilus harmani (Loden) comb. nov., in a dutch wetland, with remarks on Tubifex tubifex (Müller) (Annelida: Oligochaeta). Zootaxa, (1281), 21-39. Retrieved from: www. scopus.com

Timm, T. 1999. Distribution of freshwater oligochaetes in the west and east coastal regions of the north pacific ocean. Hydrobiologia, 406, 67-81. doi: 10.1023/A:1003749519662

Timm, T. 1997. Freshwater Oligochaeta of some urban watercourses in the russian far east. Internationale Revue Der Gesamten Hydrobiologie Und Hydrographie, 82(4), 437-467. doi: 10.1002/iroh.19970820402

Timm, T. 1998. Lumbriculidae (Oligochaeta) of Lake Taimyr. Journal of Natural History, 32(9), 1291-1301. doi: 10.1080/00222939800770641

Timm, T. 2012. Profundal oligochaete assemblages in palaearctic lakes. Turkish Journal of Zoology, 36(1), 121-131. doi: 10.3906/zo0-1002-51

Timm, T. 1994. Propappidae and aquatic Enchytraeidae (Oligochaeta) from the farthest southeast of Russia. Hydrobiologia, 278(1-3), 67-78. doi: 10.1007/BF00142312

Timm, T. 2013. The genus Potamothrix (Annelida, Oligochaeta, Tubificidae): A literature review. Estonian Journal of Ecology, 62(2), 121-136. doi: 10.3176/eco.2013.2.04

Timm, T. 1996. Tubifex tubifex (MÜLLER, 1774) (Oligochaeta, Tubificidae) in the profundal of estonian lakes. Internationale Revue Der Gesamten Hydrobiologie Und Hydrographie, 81(4), 589-596. doi: 10.1002/ iroh.19960810412

Timm, T., Arslan, N., Rüzgar, M., Martinsson, S. \& Erséus, C. 2013. Oligochaeta (Annelida) of the profundal of Lake Hazar (Turkey), with description of Potamothrix alatus Hazaricus ssp. nov. Zootaxa, 3716(2), 144-156. doi: 10.11646/zootaxa.3716.2.2

Timm, T. \& Grimm, R. 2005. What is Homochaeta naidina Bretscher, 1896 (Annelida, Oligochaeta, Naididae)? Zoosystema, 27(3), 469-482. Retrieved from: www.scopus.com

Timm, T. \& Martin, P.J. 2014. Clitellata: Oligochaeta. Thorp and covich's freshwater invertebrates: Ecology and general biology: Fourth edition. (pp. 529-549) doi: 10.1016/B978-0-12-385026-3.00021-8. Retrieved from: www.scopus.com

Timm, T. \& Rodriguez, P. 1994. Description of a new Lumbriculus species (Oligochaeta, Lumbriculidae) from the Russian Far-East. [Description d'une nouvelle espèces de Lumbriculus (Oligochaeta, Lumbriculidae) de l'Extrême-Orient russe]. Annales de Limnologie, 30(2), 95-100. doi: 10.1051/limn/1994012

Trodd, W.R., Kelly-Quinn, M., Sweeney, P. \& Quirke, B. 2005. A review of the status and distribution of the free-living freshwater Oligochaeta of Ireland. Biology and Environment, 105(1), 59-64. doi: 10.3318/ BIOE.2005.105.1.59

Tsytsugina, V.G., Gudkov, D.I., Nazarov, A.B. \& Gorbenko, V.P. 2005. Damage to chromosomes in cells of oligochaetes Stylaria lacustris in water bodies of the Chernobyl NPP exclusion zone. Hydrobiological Journal, 41(5), 97-101. doi: 10.1615/HydrobJ.v41.i5.100

Tsytsugina, V.G. \& Polikarpov, G.G. 2000. Cytogenetic and population effects in Oligochaeta from the Chernobyl zone. Radiatsionnaya Biologiya. Radioekologiya, 40(2), 226-230. Retrieved from: www.scopus.com

Tsytsugina, V.G. \& Polikarpov, G.G. 2003. Radiological effects on populations of Oligochaeta in the Chernobyl contaminated zone. Journal of Environmental Radioactivity, 66(1-2), 141-154. doi: 10.1016/50265931X(02)00120-0

Uzunov, J., Košel, V. \& Sládeček, V. 1988. Indicator value of freshwater Oligochaeta. Acta Hydrochimica et Hydrobiologica, 16(2), 173-186. doi: 10.1002/aheh.19880160207

Van Duinen, G.A., Timm, T., Smolders, A.J.P., Brock, A.M.T., Verberk, W.C.E.P. \& Esselink, H. 2006. Differential response of aquatic oligochaete species to 
increased nutrient availability - A comparative study between estonian and dutch raised bogs. Hydrobiologia, 564 (1 spec. iss.), 143-145. doi: 10.1007/s10750-005-1715-y

Vandegehuchte, M.B., Roman, Y.E., Nguyen, L.T.H., Janssen, C.R. \& De Schamphelaere, K.A.C. 2007. Toxicological availability of nickel to the benthic oligochaete Lumbriculus variegatus. Environment International, 33(6), 736-742. doi: 10.1016/j.envint.2007.02.006

Vecchi, M., Reynoldson, T.B., Pasteris, A. \& Bonomi, G. 1999. Toxicity of copper-spiked sediments to Tubifex tubifex (Oligochaeta, Tubificidae): Comparison of the 28-day reproductive bioassay with an early- life-stage bioassay. Environmental Toxicology and Chemistry, 18(6), 1173-1179. doi: 10.1897/1551-5028(1999)018<1173:TOCSST > 2.3.C0;2

Vedovini, A., Légier, P. \& Vespini, F. 1985. Oligochaetes of a river in the South Alps, the Buech. [Les Oligochètes d'une rivière des Alpes du Sud, le Buech]. Annales de Limnologie, 21(2), 117-125. doi: 10.1051/ limn/1985011

Veltz, I., Arsac, F., Biagianti-Risbourg, S., Habets, F., Lechenault, H. \& Vernet, G. 1996. Effects of platinum (Pt4+) on Lumbriculus variegatus Müller (Annelida, Oligochaetae): Acute toxicity and bioaccumulation. Archives of Environmental Contamination and Toxicology, 31(1), 63-67. Retrieved from: www.scopus.com

Veltz-Balatre, I., Biagianti-Risbourg, S. \& Vernet, G. 2000. De la régénération céphalique de l'oligochète Lumbriculus variegatus Müller à l'étude de la toxicité des métaux lourds cephalic regeneration of freshwater Oligochaeta Lumbriculus variegatus Müller used for studying heavy metal toxicity. Annee Biologique, 39(1), 39-52. Retrieved from: www. scopus.com

Verdonschot, P.F.M. 1987. Aquatic oligochaetes in ditches. Hydrobiologia, 155(1), 283-292. doi: 10.1007/BF00025661

Verdonschot, P.F.M. 2006. Beyond masses and blooms: The indicative value of oligochaetes. Hydrobiologia, 564 (1 spec. iss.), 127-142. doi: 10.1007/ s10750-005-1714- $z$

Verdonschot, P.F.M. 1999. Micro-distribution of oligochaetes in a softbottomed lowland stream (Elsbeek; the Netherlands). Hydrobiologia, 406, 149-163. doi: 10.1023/A:1003796403364

Verdonschot, P.F.M. 1989. The role of oligochaetes in the management of waters. Hydrobiologia, 180(1), 213-227. doi: 10.1007/BF00027554

Verdonschot, P.F.M. \& Ter Braak, C.J.F. 1994. An experimental manipulation of oligochaete communities in mesocosms treated with chlorpyrifos or nutrient additions: Multivariate analyses with Monte Carlo permutation tests. Hydrobiologia, 278(1-3), 251-266. doi: 10.1007/BF00142333

Vidal, D.E. \& Horne, A.J. 2003. Inheritance of mercury tolerance in the aquatic oligochaete Tubifex tubifex. Environmental Toxicology and Chemistry, 22(9), 2130-2135. doi: 10.1897/02-407

Vidal, D.E. \& Horne, A.J. 2003. Mercury toxicity in the aquatic oligochaete sparganophilus pearsei: I. Variation in resistance among populations. Archives of Environmental Contamination and Toxicology, 45(2), 184-189. doi: $10.1007 / 500244-003-0119-0$

Vivien, R. 2013. Note on the diversity of aquatic oligochaetes in the Geneva area (Switzerland). [Note sur la diversité des oligochètes aquatiques dans la région genevoise (Suisse)]. Revue Suisse de Zoologie, 120(3), 415-420. Retrieved from: www.scopus.com

Vivien, R., La Font, M. \& Perfetta, J. 2011. Proposal of heavy metal toxicity thresholds of sediments indicated by oligochaete worms in some watercourses. [Proposition d'un seuil de toxicité des métaux lourds des sédiments mis en évidence par les vers oligochètes dans quelques cours d'eau]. Bulletin de la Societe Vaudoise des Sciences Naturelles, 92(3-4), 153-164. Retrieved from: www.scopus.com

Vivien, R. \& Lafont, M. 2013. Diversity of aquatic oligochaetes in the Geneva area (Switzerland). [Diversité des oligochètes aquatiques dans la région
Genevoise (Suisse)]. Revue Suisse de Zoologie, 120(1), 161-173. Retrieved from: www.scopus.com

Vivien, R. \& Lafont, M. 2015. Faunistic note on the aquatic oligochaetes of the Geneva area and of Switzerland. [Note faunistique sur les oligochètes aquatiques de la région Genevoise et de Suisse]. Revue Suisse de Zoologie, 122(2), 207-212. doi: 10.5281/zenod0.29997

Vivien, R., Tixier, G. \& Lafont, M. 2014. Use of oligochaete communities for assessing the quality of sediments in watercourses of the Geneva area (Switzerland) and artois-picardie basin (France): Proposition of heavy metal toxicity thresholds. Ecohydrology and Hydrobiology, 14(2), 142-151. doi: 10.1016/j.ecohyd.2014.03.003

Vorob'ev, D.S., Frank, Y.A., Lushnikov, S.V., Zaloznyi, N.A. \& Noskov, Y.A. 2010. Oil decontamination of bottom sediments using Limnodrilus hoffmeisteri (Oligochaeta: Tubificidae). Contemporary Problems of Ecology, 3(1), 15-18. doi: 10.1134/\$1995425510010042

Wang, H. \& Liang, Y. 2001. A preliminary study of oligochaetes in Poyang Lake, the largest freshwater lake of China, and its vicinity, with description of a new species of Limnodrilus. Hydrobiologia, 463, 29-38. doi: $10.1023 / A: 1013126918728$

Wang, H., Xie, Z. \& Liang, Y. 1999. Records of Enchytraeidae (Clitellata) from the people's Republic of China. Hydrobiologia, 406, 57-66. doi: 10.1023/A:1003732116567

Wang, X. \& Matisoff, G. 1997. Solute transport in sediments by a large freshwater oligochaete, Branchiura sowerbyi. Environmental Science \& Technology, 31(7), 1926-1933. doi: 10.1021/es960716n

Weerasundara, A., Pathiratne, A. \& Costa, H. 2000. Species composition and abundance of littoral oligochaete fauna in Lunuwila Reservoir, Sri Lanka. International Review of Hydrobiology, 85(2-3), 223-230. doi: 10.1002/ (SICI)1522-2632(200004)85:2/3<223:AID-IROH223>3.0.C0;2-L

Wegener, J.-.M., van den Berg, G.A., Stroomberg, G.J. \& van Velzen, M.J.M. 2002. The role of sediment-feeding oligochaete Tubifex on the availability of trace metals in sediment pore waters as determined by diffusive gradients in thin films (DGT). Journal of Soils and Sediments, 2(2), 71-76. doi: 10.1007/BF02987874

Wei, Y. \& Liu, J. 2005. The discharged excess sludge treated by oligochaete. Retrieved from: www.scopus.com

Wei, Y., Van Houten, R.T., Borger, A.R., Eikelboom, D.H. \& Fan, Y. 2003. Comparison performances of membrane bioreactor and conventional activated sludge processes on sludge reduction induced by oligochaete. Environmental Science \& Technology, 37(14), 3171-3180. doi: 10.1021/ es026176d

Wei, Y., Wang, Y., Guo, X. \& Liu, J. 2009. Sludge reduction potential of the activated sludge process by integrating an oligochaete reactor. Journal of Hazardous Materials, 163(1), 87-91. doi: 10.1016/j.jhazmat.2008.06.065

Wei, Y., Zhu, H., Wang, Y., Li, J., Zhang, P., Hu, J. \& Liu, J. 2009. Nutrients release and phosphorus distribution during oligochaetes predation on activated sludge. Biochemical Engineering Journal, 43(3), 239-245. doi: 10.1016/j.bej.2008.10.004

Weider, L.J. 1992. Allozymic variation in tubificid oligochaetes from the laurentian great lakes. Hydrobiologia, 234(2), 79-85. doi: 10.1007/ BF00010863

West, C.W. \& Ankley, G.T. 1998. A laboratory assay to assess avoidance of contaminated sediments by the freshwater oligochaete Lumbriculus variegatus. Archives of Environmental Contamination and Toxicology, 35(1), 20-24. doi: $10.1007 / 5002449900343$

Westheide, W., Purschke, G. \& Middendorf, K. 1991. Spermatozoal ultrastructure of the taxon Enchytraeus (Annelida, Oligochaeta) and its significance for species discrimination and identification. Journal of Zoological Systematics and Evolutionary Research, 29(5-6), 323-342. doi: 10.1111/j.1439-0469.1991.tb00456.x 
Wetzel, M.J., Oberlin, G.E. \& Blinn, D.W. 1999. The aquatic Oligochaeta (Annelida: Clitellata) of Montezuma Well, Arizona: A near thermally constant limnocrene. Southwestern Naturalist, 44(4), 514-518. doi: $\underline{10.2307 / 3672352}$

Wetzel, M.J. \& Taylor, S.J. 2001. First records of freshwater oligochaetes (Annelida, Clitellata) from caves in Illinois and Missouri, USA. Journal of Cave and Karst Studies, 63(3), 99-104. Retrieved from: www.scopus.com

Whitaker, J.W., Pote, L.M.W. \& Hanson, L.A. 2005. Assay to detect the actinospore and myxospore stages of proliferative gill disease in oligochaetes and pond water. North American Journal of Aquaculture, 67(2), 133-137. doi: 10.1577/A03-059.1

White, D.S. \& Keilty, T.J. 1988. Burrowing avoidance assays of contaminated Detroit River sediments, using the freshwater oligochaete Stylodrilus heringianus (Lumbriculidae). Archives of Environmental Contamination and Toxicology, 17(5), 673-681. doi: 10.1007/BF01055837

White, D.S., Klahr, P.C. \& Robbins, J.A. 1987. Effects of temperature and density on sediment reworking by Stylodrilus heringianus (Oligochaeta: Lumbriculidae). Journal of Great Lakes Research, 13(2), 147-156. doi: 10.1016/S0380-1330(87)71638-4

Wieltschnig, C., Kirschner, A.K.T., Fischer, U.R. \& Velimirov, B. 2003. Top-down control of benthic heterotrophic nanoflagellates by oligochaetes and microcrustaceans in a littoral freshwater habitat. Freshwater Biology, 48(10), 1840-1849. doi: 10.1046/j.1365-2427.2003.01133.x

Wolf, K., Markiw, M.E. \& Hiltunen, J.K. 1986. Salmonid whirling disease: Tubifex tubifex (Müller) identified as the essential oligochaete in the protozoan life cycle. Journal of Fish Diseases, 9(1), 83-85. doi: 10.1111/ j.1365-2761.1986.tb00984.x

Xiao, C. \& Desser, S.S. 1998. Actinosporean stages of myxozoan parasites of oligochaetes from Lake Sasajewun, Algonquin Park, Ontario: New forms of echinactinomyxon, neoactinomyxum, aurantiactinomyxon, guyenotia, synactinomyxon and antonactinomyxon. Journal of Parasitology, 84(5), 1010-1019. doi: 10.2307/3284635

Xiao, C. \& Desser, S.S. 1998. Actinosporean stages of myxozoan parasites of oligochaetes from Lake Sasajewun, Algonquin Park, Ontario: New forms of triactinomyxon and raabeia. Journal of Parasitology, 84(5), 998-1009. doi: $10.2307 / 3284634$

Xiao, C.\& Desser, S.S. 1998. The oligochaetes and their actinosporean parasites in Lake Sasajewun, Algonquin Park, Ontario. Journal of Parasitology, 84(5), 1020-1026. doi: 10.2307/3284636

Xie, L., Lambert, D., Martin, C., Cain, D.J., Luoma, S.N. \& Buchwalter, D. 2008. Cadmium biodynamics in the oligochaete Lumbriculus variegatus and its implications for trophic transfer. Aquatic Toxicology, 86(2), 265-271. doi: 10.1016/j.aquatox.2007.11.008

Xie, Z. \& Chen, J. 2008. A redescription of Piguetiella denticulata liang and xie (Oligochaeta, Tubificidae, Naidinae) from China, with a key to the genus Piguetiella. Proceedings of the Biological Society of Washington, 121(3), 321-325. doi: 10.2988/08-08.1

Xie, Z., Shu, S., Zhang, J., Chen, J. \& Cai, Q. 2008. Oligochaete assemblages associated with macrophytes in the Liangzi Lake District, China. Journal of Freshwater Ecology, 23(2), 237-244. doi: 10.1080/02705060.2008.9664196

Yanling, L. 1987. Preliminary study of the aquatic Oligochaeta of the Changjiang (Yangtze) River. Hydrobiologia, 155(1), 195-198. doi: $\underline{10.1007 / B F 00025651}$
Yasuda, K. \& Okino, T. 1987. Distribution and seasonal changes of aquatic Oligochaeta in Lake Suwa. Japanese Journal of Limnology (Rikusuigaku Zasshi), 48(1), 1-8. doi: 10.3739/rikusui.48.1

Yasuda, K. \& Okino, T. 1988. Method for distinguishing Limnodrilus hoffmeisteri and Limnodrilus claparedeianus (Oligochaeta, Tubificidae) and its applicability in Lake Suwa. Hydrobiologia, 169(3), 307-311. doi: 10.1007/BF00007553

Yildiz, S. \& Ahiska, S. 2010. Nais stolci hrabě, 1981: A new oligochaete (Annelida: Clitellata: Naididae) species for Turkey. [Nais stolci Hrabě, 1981: Türkiye için yeni bir Oligoket (Annelida, Oligochaeta) Türü]. Turkish Journal of Zoology, 34(4), 547-549. doi: 10.3906/z00-0906-3

Yildiz, S. \& Balik, S. 2006. The Oligochaeta (Annelida) fauna of topçam Dam Lake (Aydin, Turkey). Turkish Journal of Zoology, 30(1), 83-89. Retrieved from: www.scopus.com

Yıldız, S. \& Balık, S. 2010. Nais christinae Kasprzak, 1973: An Oligochaeta species new for Turkey (Annelida: Naididae). Zoology in the Middle East, 50(1), 151-152. doi: 10.1080/09397140.2010.10638432

Yildiz, S., Ustaoğlu, M.R. \& Balik, S. 2007. Contributions to the knowledge of the Oligochaeta (Annelida) fauna of some lakes in the taurus mountain range (Turkey). Turkish Journal of Zoology, 31(3), 249-254. Retrieved from: www.scopus.com

Yokoyama, H., Ogawa, K. \& Wakabayashi, H. 1993. Some biological characteristics of actinosporeans from the oligochaete Branchiura sowerbyi. Diseases of Aquatic Organisms, 17(3), 223-228. doi: 10.3354/ da0017223

Zendt, J.S. \& Bergersen, E.P. 2000. Distribution and abundance of the aquatic oligochaete host Tubifex tubifex for the salmonid whirling disease parasite Myxobolus cerebralis in the upper Colorado River basin. North American Journal of Fisheries Management, 20(2), 502-512. doi: 10.1577/1548-8675(2000)020<0502:DAAOTA $>2.3 . C 0 ; 2$

Zeybek, M., Kalyoncu, H. \& Ertan, 0.0. 2013. The effects of environmental variables on distribution of aquatic Oligochaeta and Chironomidae at kovada channel and the Linked Lakes (Isparta, Turkey). Fresenius Environmental Bulletin, 22(11), 3160-3169. Retrieved from: www. scopus.com

Zhang, B., Li, H., Wei, Y. \& You, J. 2013. Bioaccumulation kinetics of polybrominated diphenyl ethers and decabromodiphenyl ethane from field-collected sediment in the oligochaete, Lumbriculus variegatus. Environmental Toxicology and Chemistry, 32(12), 2711-2718. doi: 10.1002/etc. 2384

Zhang, J., Chen, J. \& Xie, Z. 2007. Redescription of Nais inflata liang (Annelida: Oligochaeta) from China. Proceedings of the Biological Society of Washington, 120(3), 264-270. doi: 10.2988/0006-324X(2007)120[264:RONILA]2.0.C0;2

Zhu, H., Wei, Y.-., Wang, Y.-. \& Liu, J.-. 2008. Advances in sludge reduction induced by oligochaetes and theirs growth kinetics. Guocheng Gongcheng Xuebao - The Chinese Journal of Process Engineering, 8(5), 1030-1040. Retrieved from: www.scopus.com

Zvereva, Y.M., Mizandrontsev, I.B., Zaytseva, Y.P. \& Timoshkin, 0.A. 2015. Respiration of aquatic oligochaetes (Annelida, Oligochaeta) and peculiarities of oxygen uptake by endemic Enchytraeidae of Lake Baikal. Hydrobiological Journal, 51(5), 14-24. doi: 10.1615/HydrobJ.v51.i5.20 